UNIVERSIDADE DE SÃO PAULO

FACULDADE DE ECONOMIA, ADMINISTRAÇÃO E CONTABILIDADE DEPARTAMENTO DE ADMINISTRAÇÃO

PROGRAMA DE MESTRADO PROFISSIONAL EM EMPREENDEDORISMO

RISCOS CORPORATIVOS EM ALIANÇAS ESTRATÉGICAS: O CASO

ENVOLVENDO A GESTIONA - PEQUENA EMPRESA E A

PRICEWATERHOUSECOOPERS

Sidirley Fabiani

Orientador: Prof. Dr. Fábio Lotti Oliva

SÃO PAULO

2016 
Prof. Dr. Marco Antonio Zago

Reitor da Universidade de São Paulo

Prof. Dr. Adalberto Américo Fischmann

Diretor da Faculdade de Economia, Administração e Contabilidade

Prof. Dr. Roberto Sbragia

Chefe do Departamento de Administração

Prof. Dr. Martinho Isnard Ribeiro de Almeida

Coordenador do Programa de Mestrado Profissional em Empreendedorismo 


\title{
RISCOS CORPORATIVOS EM ALIANÇAS ESTRATÉGICAS: O CASO ENVOLVENDO A GESTIONA - PEQUENA EMPRESA E A PRICEWATERHOUSECOOPERS
}

\author{
Dissertação apresentada ao Programa de \\ Pós-Graduação em Mestrado \\ Profissional em Empreendedorismo do \\ Departamento de Administração da \\ Faculdade de Economia, Administração \\ e Contabilidade da Universidade de São \\ Paulo, como requisito parcial para a \\ obtenção do título de Mestre em \\ Ciências.
}

Orientador: Prof. Dr. Fábio Lotti Oliva

\section{Versão Corrigida}

(versão original disponível na Biblioteca da Faculdade de Economia, Administração e Contabilidade)

\section{SÃO PAULO}




\section{FICHA CATALOGRÁFICA}

Elaborada pela Seção de Processamento Técnico do SBD/FEA/USP

\section{Fabiani, Sidirley}

Riscos corporativos em alianças estratégicas: o caso envolvendo a Gestiona - pequena empresa e a PricewaterhouseCoopers / Sidirley Fabiani -- São Paulo, 2016.

$126 \mathrm{p}$.

Dissertação (Mestrado) - Universidade de São Paulo, 2016. Orientador: Fábio Lotti Oliva.

1. Empreendedorismo 2. Alianças estratégicas 3. Riscos corporativos 4. Gestão estratégica de riscos 5 . Administração de pequenas e médias empresas 6. Estratégia corporativa I. Universidade de São Paulo. Faculdade de Economia, Administração e Contabilidade. II. Título.

CDD - 658.421 


\section{AGRADECIMENTOS}

Começo agradecendo aos meus pais, Alcides Dutra da Silva e Isabel Fabiani da Silva, que me ensinaram princípios, valores e virtudes fundamentais para o exercício da cidadania com responsabilidade social e ética, em especial minha mãe, que não mediu esforços para me proporcionar acesso à boa educação, permitindo, em última análise, que esta tese fosse concebida;

À minha esposa, Luciana Paula Fabiani, que conviveu e sofreu ao longo desta jornada de descobrimento e crescimento pessoal e intelectual;

À Universidade de São Paulo, em especial à Escola Politécnica e à Faculdade de Economia, Administração e Contabilidade, ambientes onde passei anos maravilhosos repletos de aprendizado e desafios, fiz grandes amigos e obtive formação sólida e abrangente, que fez de mim um profissional comprometido com o desenvolvimento sustentável do país.

Ao Programa de Mestrado Profissional em Empreendedorismo da Faculdade de Economia, Administração e Contabilidade da Universidade de São Paulo, em especial ao Professor Doutor Martinho Isnard Ribeiro de Almeida, pelo convite para participar do respectivo processo seletivo, e também aos Professores Doutores Marcelo Caldeira Pedroso e Fábio Lotti Oliva, que possibilitaram a realização do curso e desta dissertação;

Ao meu Orientador Doutor Fábio Lotti Olive, primeiramente pela paciência e, evidentemente, pela orientação, estímulo e compreensão durante esta jornada;

Por fim, mas não menos importante, aos Professores Doutores Martinho Isnard Ribeiro de Almeida, Nuno Manoel Martins Dias Fouto e Marco Antonio Pinheiro da Silveira, por todas as considerações, críticas e sugestões que melhoraram substancialmente a estrutura e o conteúdo desta dissertação. 
“A coisa mais indispensável a um homem é reconhecer o uso que deve fazer do seu próprio conhecimento" Platão

"Por vezes sentimos que aquilo que fazemos não é senão uma gota de água no mar, mas o mar seria menor se lhe faltasse uma gota" Madre Teresa de Calcutá 


\section{RESUMO}

Diante do aumento da concorrência e da complexidade dos projetos e especificidades dos serviços business-to-business, o empreendedor pode adotar estratégias corporativas para manter a competitividade e superar barreiras comerciais para atuar em novos mercados e acessar clientes de grande porte, por meio, por exemplo, de alianças estratégicas, ou seja, acordos de cooperação entre empresas para o compartilhamento de riscos e investimentos, complementaridade de competências e acesso a recursos, mercados e clientes não disponíveis de forma independente. No entanto, tais alianças, ao mesmo tempo que apresentam oportunidades como ampliação do mercado e do escopo de atuação, também implicam riscos corporativos para os agentes envolvidos, especialmente o pequeno empreendedor quando associado a uma empresa de grande porte. Este estudo tem como finalidade propor uma estrutura para analisar os principais riscos corporativos envolvidos no processo de formação e ao longo da aliança estratégica entre uma empresa de pequeno porte e uma empresa de grande porte. Para tanto, realizou-se um estudo de caso único com base no processo de formação e desenvolvimento da aliança estratégica firmada entre a Gestiona, consultoria brasileira de pequeno porte que atua no setor de gestão da inovação para empresas fixadas em território nacional de todos os portes e setores, e a PricewaterhouseCoopers (PwC). Sendo assim, este estudo identifica os elementos estruturais da aliança estratégica entre a Gestiona e a $\mathrm{PwC}$, bem como os principais riscos corporativos, com forte ênfase para o relacionamento interpessoal, além de propor uma estrutura de riscos corporativos para análise de contextos correlatos. Por fim, também é objeto de investigação deste estudo o nível de maturidade dessa aliança estratégica.

Palavras-chave: Empreendedorismo; Alianças Estratégicas; Riscos Corporativos; Gestão Estratégica de Riscos; Administração de Pequenas e Médias Empresas; Estratégia Corporativa. 


\begin{abstract}
Faced with increased competition and complexity of the projects and specificities of business-to-business services, the small entrepreneur can adopt corporate strategies to remain competitive and overcome trade barriers to operating in new markets and access large clients through, for example, strategic alliances, that is cooperation agreements between companies with risk-sharing objectives and investments, complementary skills and access to resources, markets and customers not available independently. However, such alliances, while presenting opportunities such as market expansion and scope of action, also imply corporate risks for the agents involved, especially the small entrepreneur when associated with a large company. This study aims to propose a structure to analyze the main corporate risks involved in the training process and throughout the strategic alliance between a small company and a large company. A single case study was carried out based on the training and development process of the strategic alliance signed between Gestiona, a small Brazilian consultancy that operates in the innovation management sector for companies established in national territory of all sizes and sectors, and PricewaterhouseCoopers $(P w C)$. Thus, this study identifies the structural elements of the strategic alliance between Gestiona and $P w C$, as well as the main corporate risks, with a strong emphasis on interpersonal relationships, as well as proposing a corporate risk structure to analyze related contexts. Finally, the study also investigates the level of maturity of this strategic alliance.
\end{abstract}

Keywords: Entrepreneurship; Strategic Alliances; Corporate Risk; Strategic Risk Management; Management of Small and Medium Enterprises; Corporate Strategy. 


\section{SUMÁRIO}

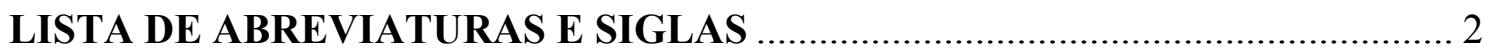

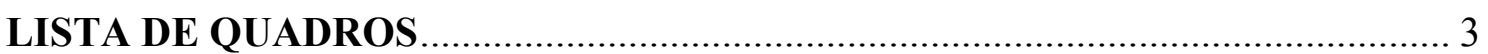

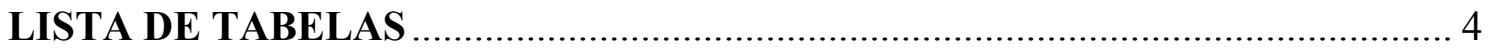

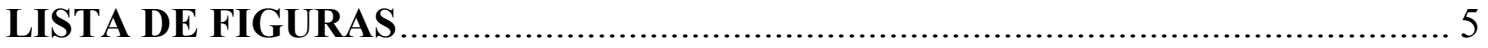

1. INTRODUÇÃ

1.1. Definição da situação-problema .......................................................................... 7

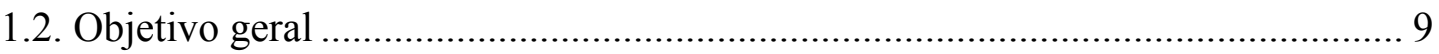

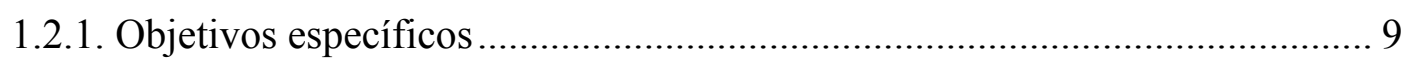

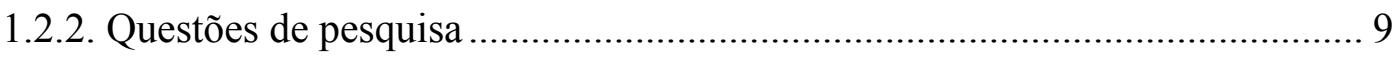

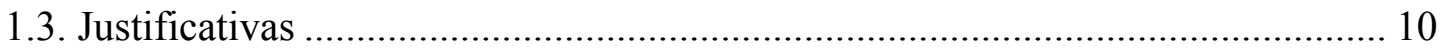

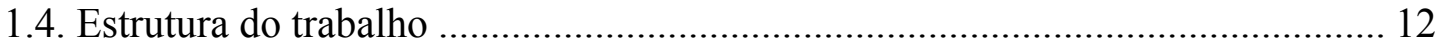

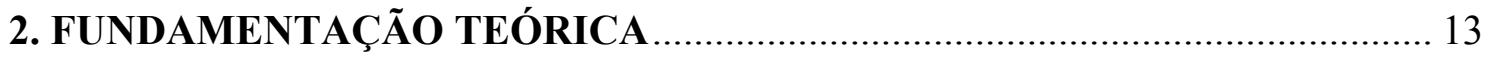

2.2. Estratégia de crescimento e tipos de empreendedorismo .................................... 14

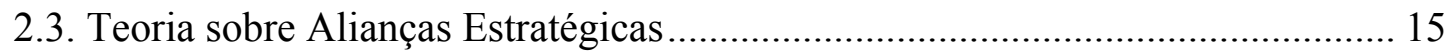

2.3.1 Conceito e Tipos de Alianças Estratégicas................................................. 16

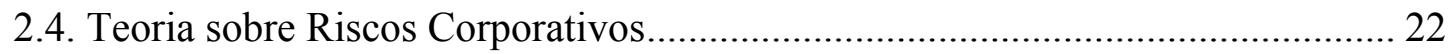

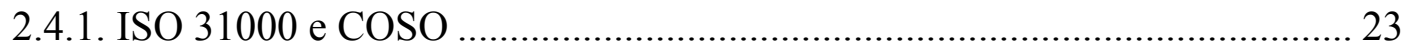

2.5. Teoria sobre gerenciamento de riscos corporativos ........................................ 31

2.6. Teoria para análise de riscos corporativos em alianças estratégicas ................... 36

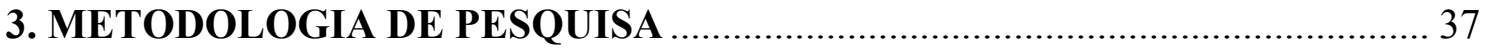

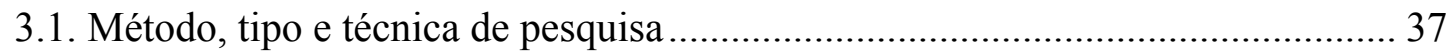

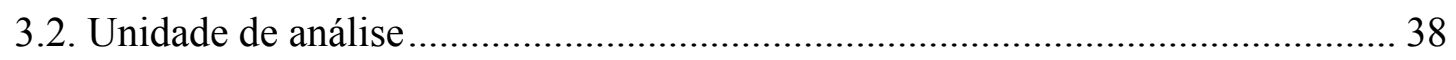

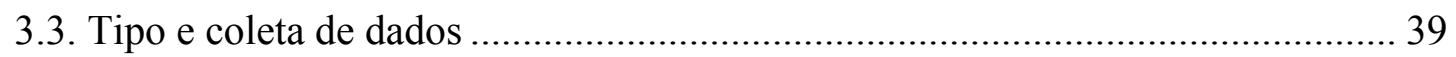

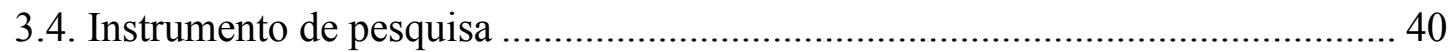

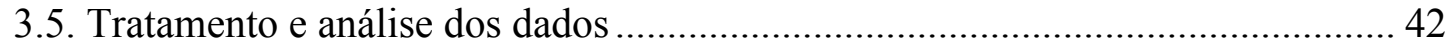

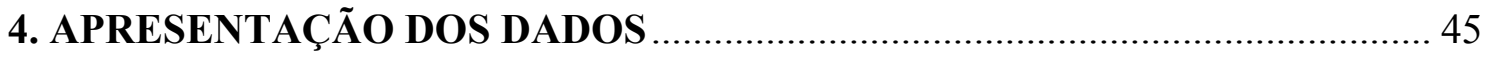

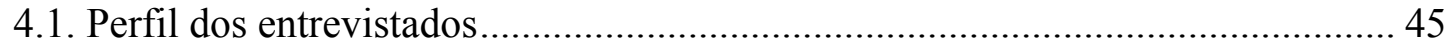

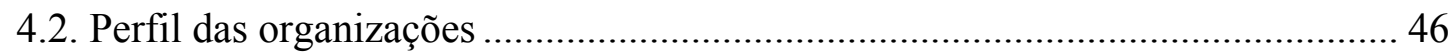

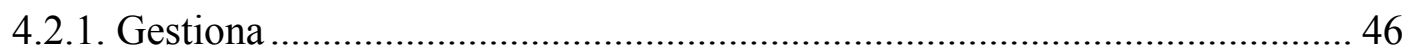

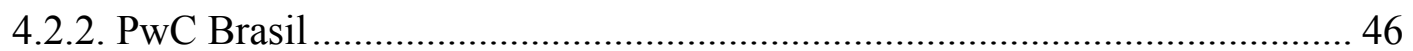

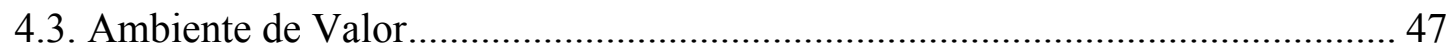

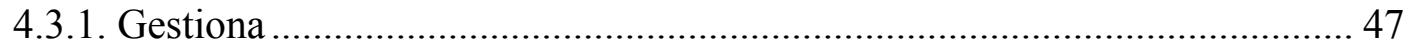

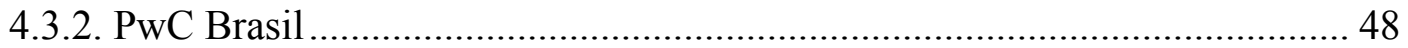

4.4. Objetivos e componentes do gerenciamento de riscos corporativos ................... 50 


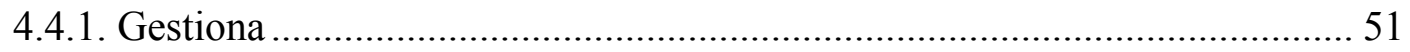

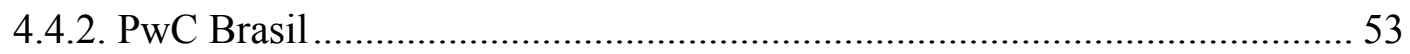

4.5. Contexto da Aliança Estratégica entre Gestiona e PwC ...................................... 55

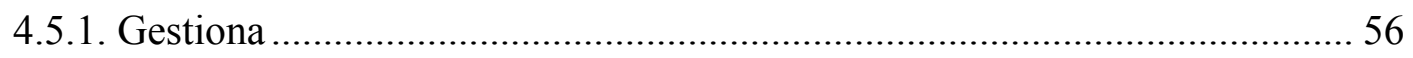

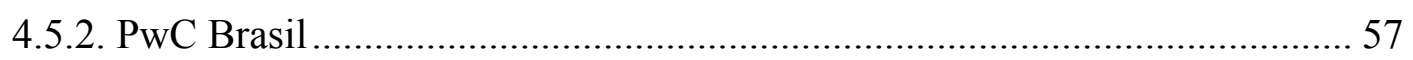

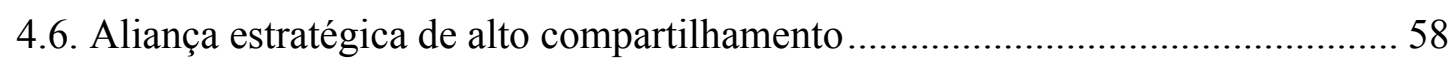

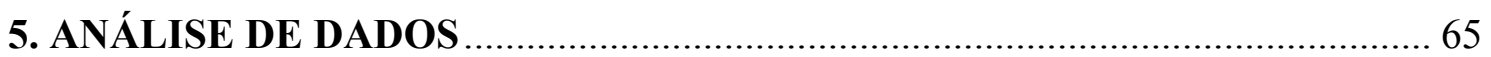

5.1. Identificação dos principais riscos corporativos para a Gestiona....................... 65

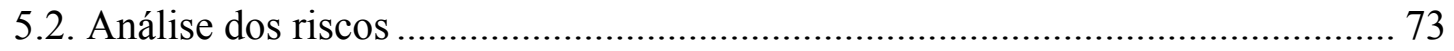

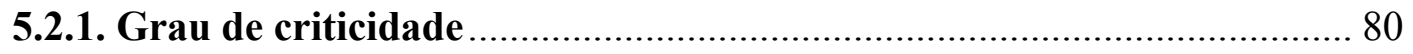

5.3. Avaliação do nível de maturidade da Gestiona em GCM .................................. 85

5.4. Avaliação do nível de estabilidade e eficácia da aliança entre Gestiona e PwC. 90

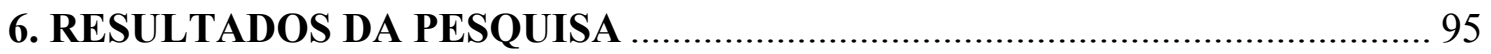

6.1. Riscos corporativos para a Gestiona envolvidos na Aliança .............................. 95

6.2. Resultado da análise dos riscos para a Gestiona envolvidos na Aliança........... 101

6.3. Nível de maturidade da Gestiona em gestão de riscos corporativos ................. 106

6.4. Nível de estabilidade e eficiência da aliança estratégica entre Gestiona e PwC 108

6.5. Estrutura para análise dos riscos corporativos para a pequena empresa em Alianças Estratégicas com Grandes Empresas ......................................................... 109

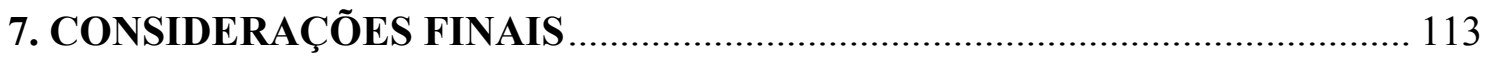

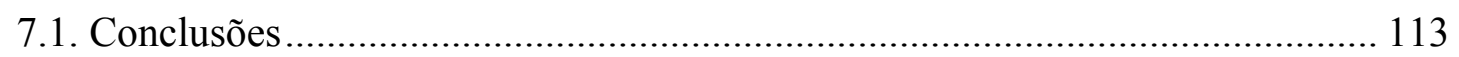

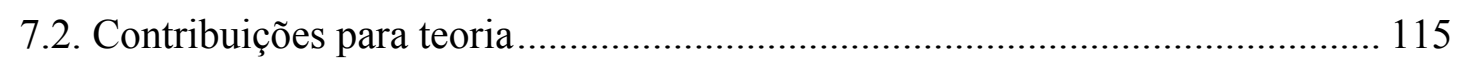

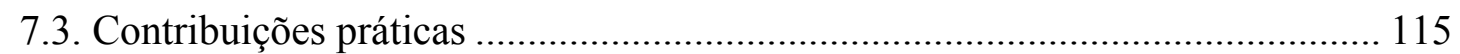

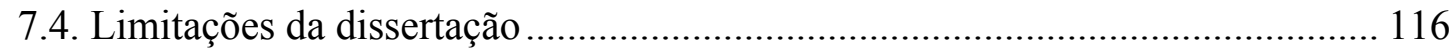

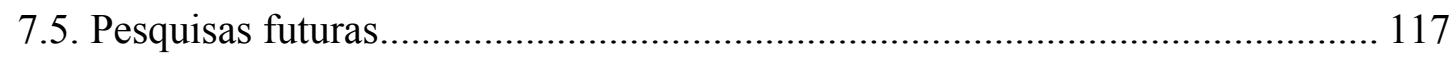

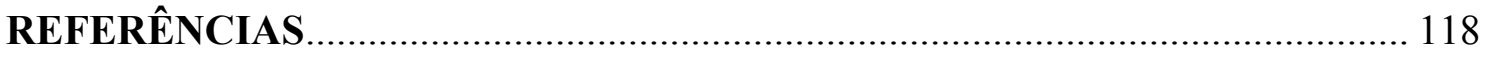

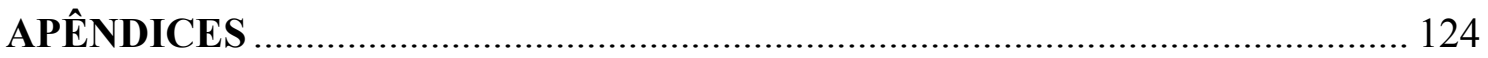






\section{LISTA DE ABREVIATURAS E SIGLAS}

ABNT: Associação Brasileira de Normas Técnicas

B2B: Business-to-Business

B2C: Business-to-Consumer

CEO: Chief Executive Officer

COSO: Comitê de Organizações Patrocinadoras da Treadway

DTT: Deloitte Touche Tohmatsu

GRCorp: Gerenciamento de Riscos Corporativos

ERM: Enterprise Risk Management

EY: Ernst \& Young

FR: Fator de Riscos

GC: Grau de Criticidade

GEM: Global Entrepreneurship Monitor

GRC: Gestão de Riscos Corporativos

IBGC: Instituto Brasileiro de Governança Corporativa

IO: Impacto na Organização

ISO: International Organization for Standartization

LER: Lesão por Esforço Repetitivo

MCTI: Ministério da Ciência Tecnologia e Inovação

NBR: Norma Brasileira

PIB: Produto Interno Bruto

PMO: Project Management Office

PO: Probabilidade de Ocorrência

PWC: PricewaterhouseCoopers

SEBRAE: Serviço Brasileiro de Apoio às Micro e Pequenas Empresas

TI: Tecnologia da Informação

TTE: Taxa Total de Empreendedores 


\section{LISTA DE QUADROS}

Quadro 1 - Diferentes tipos de alianças estratégicas..................................................

Quadro 2 - Categorias de alianças versus teoria dominante.......................................21

Quadro 3 - Riscos corporativos no ambiente de valor..................................................24

Quadro 4 - Resumo da relação entre objetivos, perguntas, teorias e análise...................31

Quadro 5 - Identificação dos riscos e respectivas dimensões de origem........................84

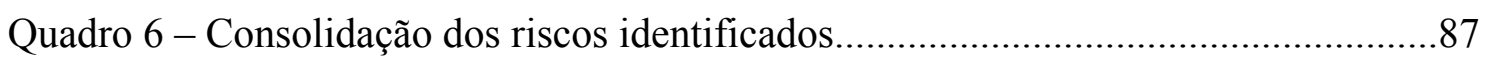

Quadro 7 - Consolidação das dimensões correlatas...................................................... 89

Quadro 8 - Dimensões consolidadas versus riscos consolidados.................................90

Quadro 9 - Riscos identificados a partir das dimensões do COSO (2007)...................108

Quadro 10 - Riscos identificados a partir das dimensões do ambiente de valor............109

Quadro 11 - Riscos identificados a partir das dimensões de Das e Teng (1998)..........108

Quadro 12 - Riscos identificados a partir das dimensões de Maloni e Belton (1997)..110

Quadro 13 - Riscos identificados a partir das dimensões de Bruno (1999)..................111

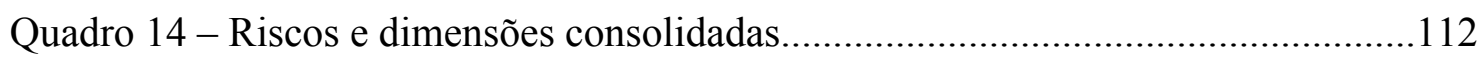

Quadro 15 - Aplicação dos fatores explicativos à gestão de riscos da Gestiona...........120

Quadro 16 - Análise do nível de maturidade da Gestiona em GCM...........................120

Quadro 17 - Nível de estabilidade e eficiência da aliança entre Gestiona e PwC........120

Quadro 18 - Estrutura para análise de riscos comparativos antes e ao longo de uma

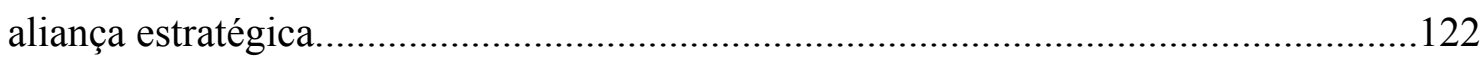




\section{LISTA DE TABELAS}

Tabela 1 - Porte das empresas com base no número de empregados............................49

Tabela 2 - Grau de criticidade dos riscos consolidados..............................................92

Tabela 3 - Ordenação por grau de criticidade dos riscos consolidados.........................94

Tabela 4 - Principais riscos consolidados por dimensão consolidada............................96

Tabela 5 - Riscos corporativos relacionados aos eventos do ambiente de negócios......97

Tabela 6 - Principais riscos e dimensões, impactos e grau de criticidade....................114

Tabela 7 - Principais riscos por dimensão consolidada...............................................116

Tabela 8 - Ordenação por grau de criticidade das dimensões consolidadas.................118

Tabela 9 - Riscos e criticidade associados aos eventos do ambiente de negócios........118 


\section{LISTA DE FIGURAS}

Figura 1 - Estrutura da revisão bibliográfica e suas delimitações.................................11

Figura 2 - Tipos de empreendedorismo corporativo externo.......................................13

Figura 3 - Opções estruturais de Alianças Estratégicas...............................................20

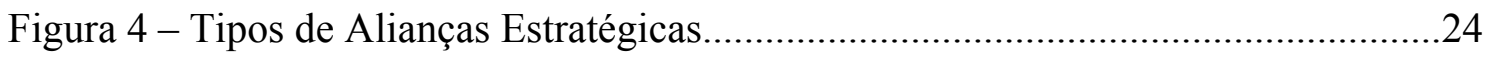

Figura 5 - Matriz tridimensional de relacionamento direto entre objetivos

organizacionais e componentes do gerenciamento de riscos corporativos......................32

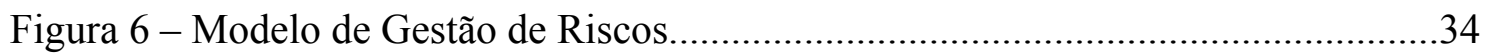

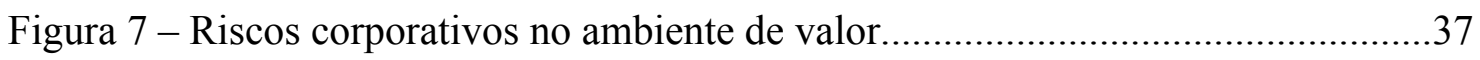

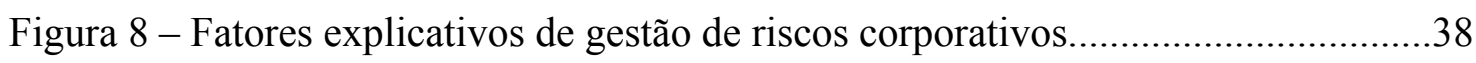

Figura 9 - Nível de maturidade na gestão de riscos corporativos..................................39

Figura 10 - Modelo para análise de estabilidade e eficácia em alianças de alto grau de compartilhamento. 


\section{INTRODUÇÃO}

Existe um número crescente de pessoas dispostas a empreender na economia brasileira. Segundo a Pesquisa do Global Entrepreneurship Monitor (GEM, 2014), o empreendedorismo no Brasil está crescendo desde 2011; em 2014, a Taxa Total de Empreendedores (TTE) foi de 34,5\%, cerca de $2 \%$ maior que a do ano anterior, e, no último triênio, o aumento do número de empreendedores no país foi de quase dez pontos percentuais. Além disso, nota-se o aumento da complexidade dos projetos e especificidades dos serviços business-to-business (B2B), exigindo um grau de especialização cada vez maior em diversas áreas, o que, por sua vez, incentiva alianças estratégicas entre as empresas de modo a oferecer soluções completas e customizadas para seus clientes.

Nesse contexto, o micro e o pequeno empreendedor buscam alternativas para manter a competitividade e superar barreiras comerciais para atuar em novos mercados e acessar clientes de grande porte. Entre essas alternativas destacam-se as alianças estratégicas bilaterais, ou seja, acordos de cooperação entre empresas com o objetivo de compartilhamento de riscos e investimentos, complementaridade de competências e acesso a recursos, mercados e clientes não disponíveis de forma independente.

\subsection{Definição da situação-problema}

O aumento da diversidade de tecnologias e da complexidade dos projetos e especificidades dos serviços, ainda mais no contexto da globalização, exige um grau de especialização cada vez maior em vários setores da economia. Nesta nova configuração, as pequenas empresas não se furtaram a essa realidade e vêm buscando, a todo o momento, alternativas para se manter competitivas e atuantes. Verschoore (2003) observa que tais empresas, em um desenvolvimento local, não conseguem competir isoladas e que as grandes estruturas não apresentam soluções satisfatórias para lidar com essa complexidade econômica; caberia, então, às parcerias, entre elas, as alianças estratégicas, despontar como a alternativa organizacional mais apropriada para atender às necessidades das atividades do presente e, com maior proeminência, do futuro. 
Nessa temática, o surgimento dos relacionamentos interorganizacionais tornaram-se frequentes, tais como alianças estratégicas, joint ventures, clusters, arranjos organizacionais e redes de empresas. Nesse sentido, Contractor e Lorange (1988) entendem que os executivos devem aprender a arte da competição e da cooperação como aspectos igualmente válidos à estratégia corporativa. Alternativos, pois é possível atuar sozinho no mercado ou em parceria com outras empresas. E simultâneos, pois mesmo optando por estabelecer uma aliança a empresa continua competindo no mercado e, dessa forma, diferentes tipos de organizações passam a ver na cooperação um importante caminho para aumentar a competitividade por meio do compartilhamento de informações, tecnologias, recursos, oportunidades e riscos.

No entanto, tais alianças, ao mesmo tempo em que apresentam oportunidades como a ampliação do mercado e do escopo de atuação, também apresentam riscos aos agentes envolvidos, especialmente às empresas de pequeno porte. Assim, espera-se contribuir para a delimitação destes riscos de modo a orientar a tomada de decisão por parte do pequeno empreendedor e, também, a gestão dos riscos ao longo da aliança estratégica.

Isto posto, temos de um lado a Gestiona, empresa fundada em 2004 e inicialmente constituída exclusivamente pelo sócio-fundador, que atuava como consultor independente e/ou sob a bandeira de outras consultorias (GESTIONA, 2015) no setor de serviços business-to-business (B2B). Com atuação em todo o território nacional, enquadra-se como microempresa (até 19 empregados) e como empresa de pequeno porte (receita bruta anual maior que $\mathrm{R} \$ 2,4$ milhões e menor ou igual a $\mathrm{R} \$ 16$ milhões).

De outro lado, a PwC, fundada em Londres, em 1849, é hoje uma das maiores prestadoras de serviços profissionais do mundo nas áreas de auditoria, consultoria e outros serviços acessórios para todo tipo de empresa e setor da economia. Presente em 157 países, possui mais de 223.000 funcionários e faturamento de US\$ 32,1 bilhões em 2015. No Brasil desde 1915, atualmente conta com cerca de 5.000 profissionais distribuídos em 16 escritórios ao longo do território nacional e faturamento superior a R\$ 1 bilhão em 2015 (PWC, 2016). 
Ambas iniciaram o processo de negociação, que durou cerca de 3 meses, no intuito de firmarem uma aliança estratégica com foco na atuação conjunta em serviços relacionados aos incentivos fiscais à inovação. E, com base em certas premissas e na análise das ameaças e oportunidades, a aliança teve início e perdura até o momento.

Assim sendo, pautando-nos no supracitado, e considerando o período dos dois primeiros anos da aliança estratégica entre a Gestiona e a PwC, propõe-se o objetivo geral e os objetivos específicos a seguir.

\subsection{Objetivo geral}

O objetivo da pesquisa é a proposição de uma estrutura para análise dos riscos corporativos envolvidos no processo de formação e ao longo da aliança estratégica entre a Gestiona e a PwC.

\subsubsection{Objetivos específicos}

Como objetivos específicos, o estudo pretende:

i. Identificar os riscos corporativos para a Gestiona no processo de formação e ao longo da aliança estratégica com a PwC;

ii. Analisar os riscos corporativos para a Gestiona no processo de formação e ao longo da aliança estratégica com a PwC;

iii. Avaliar o nível de maturidade da Gestiona em gestão de riscos corporativos;

iv. Avaliar o nível de estabilidade e eficácia da aliança entre Gestiona e PwC;

v. Propor um conjunto de fatores de risco a serem considerados pelas empresas no processo de formação e ao longo de uma aliança estratégica com grandes empresas.

\subsubsection{Questões de pesquisa}

Para atender aos objetivos propostos, pretende-se, ao final deste estudo, obter respostas para as seguintes questões: 
i. (Identificação) Quais são os riscos corporativos para a Gestiona no processo de formação e ao longo da aliança estratégica com a PwC?

ii. (Análise) Quais são os principais riscos corporativos e respectivos impactos para a Gestiona no processo de formação e ao longo da aliança estratégica com a PwC?

iii. Qual é o nível de maturidade da Gestiona em gestão de riscos corporativos?

iv. Qual o nível de estabilidade e eficácia da aliança estratégica entre Gestiona e PwC?

v. Quais riscos corporativos podem ser considerados no processo de formação e ao longo de uma aliança estratégica com outras empresas?

Foram adotadas algumas proposições teóricas para o desenvolvimento deste estudo, todas baseadas na seguinte proposição genérica:

"Existem fatores de risco relevantes na aliança estratégica envolvendo empresas de pequeno e grande porte".

Essa proposição, por sua vez, desdobra-se, em termos práticos, na seguinte hipótese:

“A identificação dos riscos para a pequena empresa e sua ponderação segundo a natureza das empresas envolvidas podem ser utilizadas para a tomada de decisão do empreendedor e para a gestão dos riscos corporativos em situações semelhantes".

\subsection{Justificativas}

Apesar de as alianças estratégicas já existirem há algum tempo, é na década de 1990 que se percebe uma rápida aceleração deste tipo de acordo de cooperação, seu escopo e sua coexistência com outras relações organizacionais (HARBISON; PEKAR, 1998). Por conseguinte, é nesse mesmo momento que se ampliam as pesquisas acadêmicas sobre o 
tema, motivadas por sua novidade como fenômeno social a ser investigado e pelo crescente interesse empresarial.

A cooperação se torna imperativa para as empresas no novo contexto competitivo, permeado pela inovação contínua, globalização, aumento da concorrência, abertura e saturação dos mercados e diluição dos riscos. Logo, as alianças estratégicas são vistas como uma maneira bastante lógica de acessar e desenvolver novos mercados, sejam eles geográficos ou de negócios, para aquisição de novos conhecimentos e tecnologias, para obtenção de economias de escala e para o desenvolvimento de novos produtos e redução de investimentos e riscos. Segundo Jonash e Sommerlatte (2001), nos dias atuais estabeleceu-se praticamente um consenso de que é quase impossível para uma empresa manter suas vantagens competitivas sem a adoção de atividades de cooperação externa (JONASH; SOMMERLATTE, 2001).

A definição do parceiro pode ser considerada a atividade mais importante no processo de formação da aliança (DACIN et al., 1997; ELMUTI; KATHAWALA, 2001; SORENSEN; REVE, 1998), porém geralmente é subestimada (STAFFORD, 1994; KOZA, LEWIN, 2000; MEDCOF, 1997). De forma contundente, a seleção do parceiro mais adequado é fundamental no processo de seleção (DACIN et al., 1997; DEVLIN, BLEACKLEY, 1988; HITT, 1998).

Por fim, justifica-se a escolha da aliança estratégica entre a Gestiona e a PwC por diversos motivos: primeiro, por envolver um empreendedor ou decisor de uma pequena empresa com uma empresa de classe mundial, no caso a PwC. Tal relação suscita, além das indagações e riscos convencionais envolvendo alianças estratégicas, diversas outras forças e condições, que, apesar da raridade do fato, ou seja, uma aliança entre empresas de porte e cultura tão distintos, podem contribuir tanto para a teoria quanto para inúmeros empreendedores e/ou decisores que vão vivenciar (na verdade, muitos já estão vivenciando) situações semelhantes ou próximas dessa. Assim, espera-se que este trabalho auxilie, em termos práticos, esses gestores a tomar decisões mais conscientes e, consequentemente, com maior probabilidade de êxito. 


\subsection{Estrutura do trabalho}

Este trabalho está organizado em 7 capítulos. O primeiro é destinado à introdução, composta do contexto, problemática, questões de pesquisa, objetivos, justificativa e estrutura. O segundo capítulo traz a fundamentação teórica, base para todo o trabalho. Em seguida, o capítulo terceiro contempla a metodologia de pesquisa adotada. O quarto capítulo apresenta os dados primários e secundários. O quinto capítulo analisa os dados com base na metodologia e o sexto capítulo contempla os resultados da dissertação. Já o sétimo capítulo faz as considerações finais, ou seja, conclusões, contribuições, limitações e proposições para novos estudos. Por fim, apresentam-se as referências bibliográficas e o apêndice, com destaque para o instrumento de pesquisa. 


\section{FUNDAMENTAÇÃO TEÓRICA}

Esta dissertação busca analisar a gestão dos riscos corporativos no processo de formação e ao longo da aliança estratégica entre a Gestiona e a PwC. Dessa forma, este capítulo ocupa-se da fundamentação teórica e dos conceitos envolvidos que suportam o método adotado, bem como as análises e conclusões, de modo a cumprir os objetivos propostos. Para tanto, faz-se necessário apresentar as seguintes teorias e modelos: (i) Tipos de empreendedorismo; (ii) Estratégia de Crescimento; (iii) Teoria sobre Alianças Estratégicas; (iv) Gestão de Riscos Corporativos; e (v) Maturidade e Riscos Corporativos em Alianças Estratégicas, conforme a Figura 1.

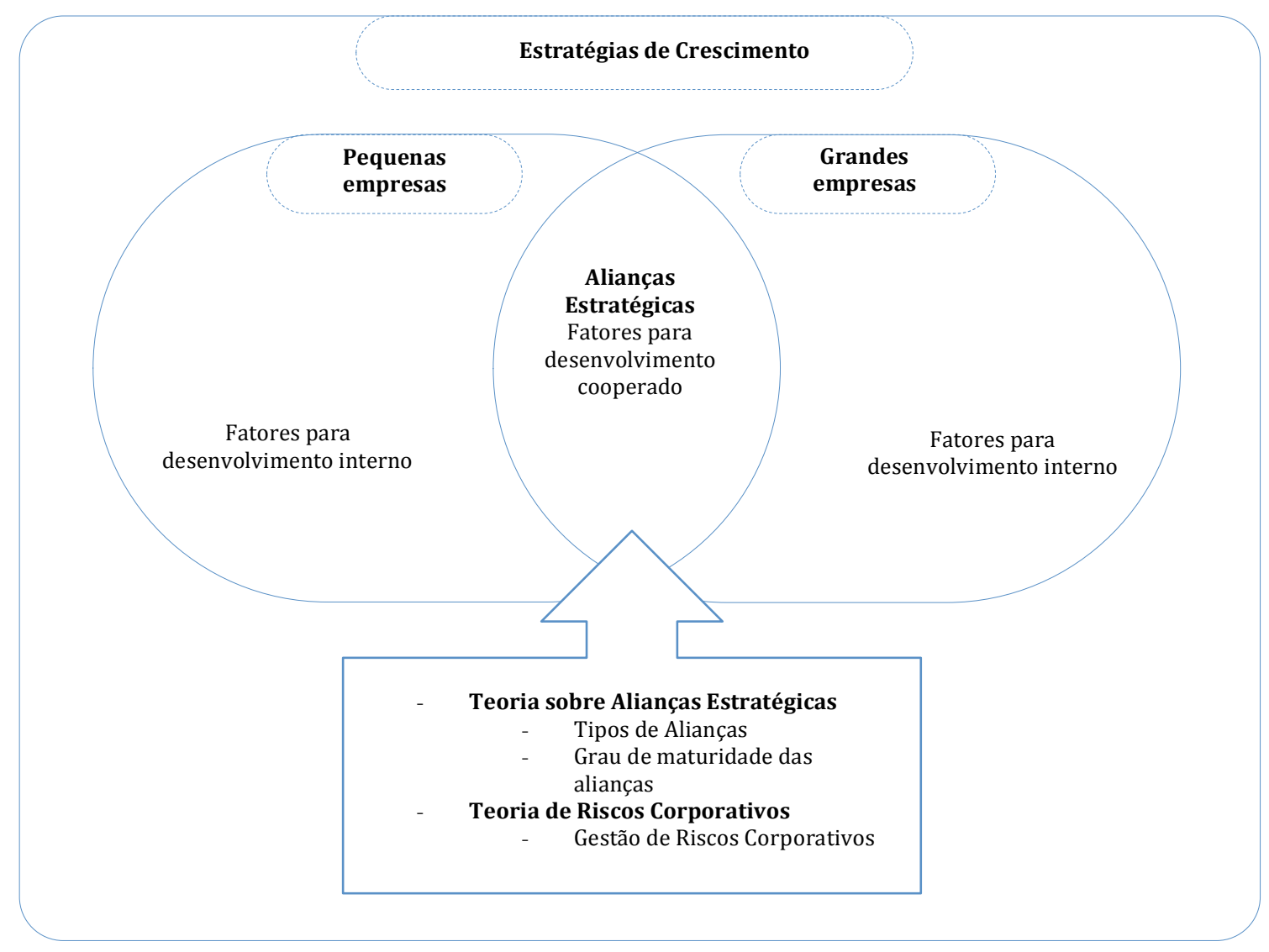

Figura 1 - Estrutura da Revisão Bibliográfica e suas delimitações Fonte: 0 autor.

\subsection{Tipos de empreendedor}

Segundo Vérin (1982), o termo empreendedor pode ser interpretado como referindo-se a 
alguém que assume riscos e inicia algo novo. Originou-se no século XII, no ambiente militar, e começou a fazer parte do universo dos negócios entre o século XII e o século XVIII, da Revolução Industrial. Já Cunningham e Lischeron (1991) afirmam que o termo deriva da língua francesa, originou-se no ambiente militar, mas passou a ser associado a pessoas que corriam riscos e incertezas motivados pela inovação.

Independentemente disso, o fato relevante é que em meados do século $\mathrm{XX}$ diversos autores, entre eles Schumpeter (1949), Collins (1964), McClelland (1970) e Cantillon (1978), estabeleceram uma relação entre o termo empreendedor e a figura do empresário no contexto do desenvolvimento econômico, e o associaram à criatividade, realização pessoal, iniciativa, inovação e, inexoravelmente, à capacidade de correr riscos.

Mais recentemente, Dornelas (2007) definiu 7 tipos de empreendedores: mitológico (nato); inesperado (que percebe e aproveita uma oportunidade); serial (criador de vários novos negócios); empreendedor corporativo (executivo que busca novas oportunidades para a empresa em que atua); social (focado no desenvolvimento da sociedade); herdeiro (sucessor familiar); normal (planejador).

\subsection{Estratégia de crescimento e tipos de empreendedorismo}

Ansoff (1965) propõe uma matriz de crescimento produto/mercado que relaciona mercado atual e novo com produto atual e novo, resultando na seguinte classificação: desenvolvimento de mercado, desenvolvimento de produto, penetração e diversificação. Já Gaj (1990) classifica a matriz de Ansoff como estratégias de crescimento intensivo, e cria o grupo de estratégia de crescimento integrativo: vertical para baixo (insumos e/ou fornecedores), horizontal (participação acionária em concorrentes) e vertical para cima (fabricação de produtos intermediários ou distribuição de produtos acabados). A diversificação de uma empresa ou empreendedorismo corporativo corresponde aos esforços, internos ou externos, para a criação ou entrada num novo negócio, ou seja, que envolva tecnologia ou mercado distintos dos atuais (ELORANTA, 2000, p. 5). 
A partir da subdivisão do empreendedorismo corporativo em interno (iniciativas dentro das fronteiras da empresa) e externo (empreendimentos autônomos), Keil (2000) propõe a divisão deste em 3 categorias: venture capital, alianças e arranjos transformacionais. $\mathrm{E}$ no nível seguinte, particularmente no que tange às alianças, sugere a divisão destas em alianças sem participação acionária, participações minoritárias e joint ventures, como pode ser visto na Figura 2.

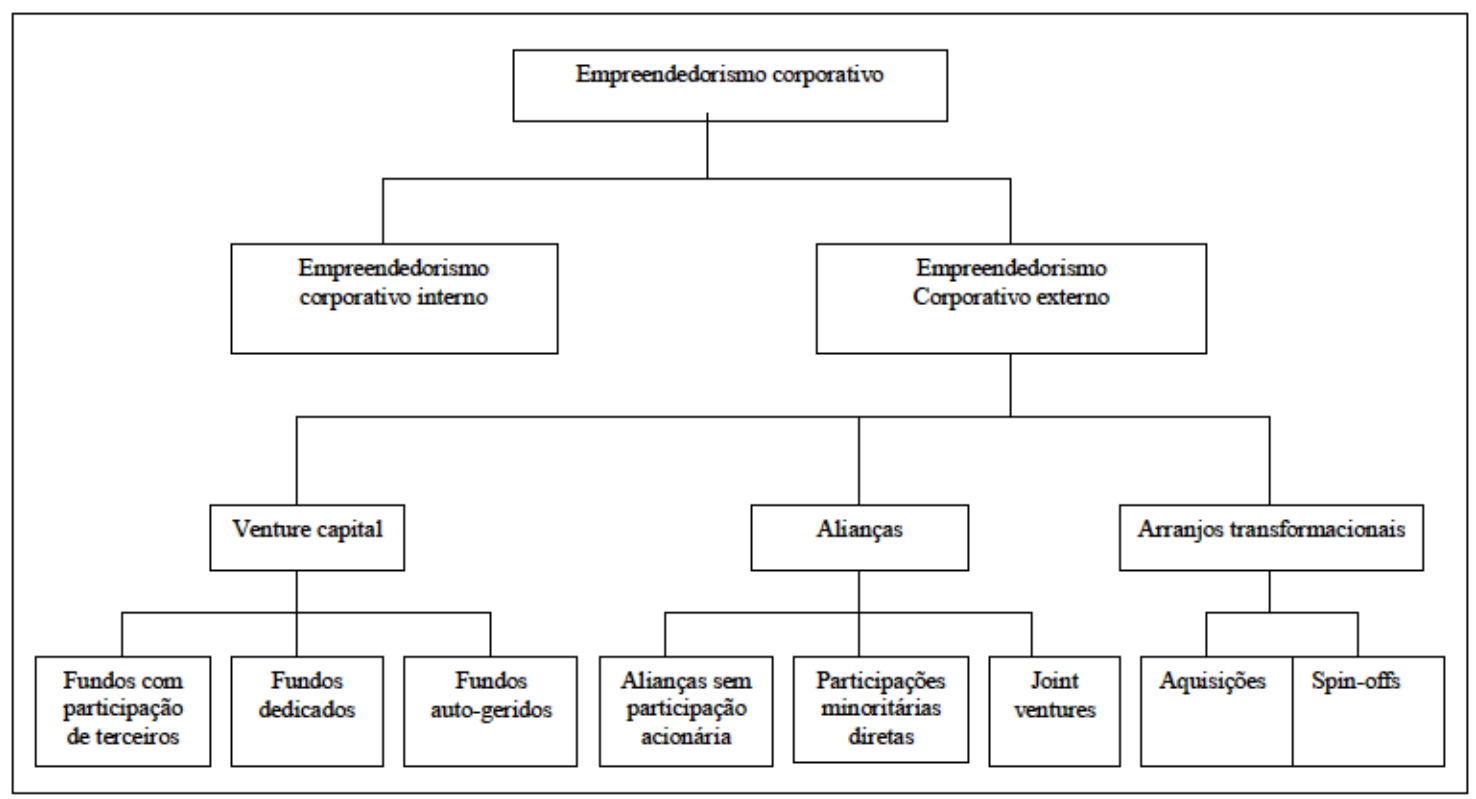

Figura 2 - Tipos de empreendedorismo corporativo externo Fonte: KEIL, 2000, p. 76.

Roberts e Berry (1985) caracterizam 7 modalidades de entrada segundo graus de familiaridade com mercados e tecnologias, a saber: desenvolvimento interno, aquisições, licenciamentos, internal ventures, joint ventures, participações minoritárias e aquisições educativas. Em seguida, elencaram as principais vantagens e desvantagens de cada uma. No caso particular das Joint Ventures ou Alianças, as vantagens são: as parcerias tecnológicas e mercadológicas podem explorar as sinergias das empresas e há minimização de risco; a desvantagem é o conflito potencial entre parceiros (ROBERTS; BERRY, 1985, p. 8).

\subsection{Teoria sobre Alianças Estratégicas}

Dodgson (1993) afirma que há inúmeras definições para o termo alianças: "acordos de 
colaboração", "associações", "acordos de cooperação", "network" e "parcerias", utilizados em pesquisa, desenvolvimento, produção e marketing com o intuito de melhorar a capacidade de desenvolvimento dos produtos e melhorar a eficiência na produção.

No que tange aos acordos de cooperação, o foco está na minimização do risco de a empresa competir sozinha no mercado, tornando assim mais fácil a tarefa de descobrir se o produto ou serviço (inovação) será validado pelos consumidores (mercado). Em outras palavras, isso significa que a abordagem cooperativa, em contraposição à abordagem competitiva, pode ser mais realista do que a abordagem competitiva, pois tende a proporcionar aos parceiros maior probabilidade de sucesso em um contexto competitivo do que se estes entrassem sozinhos em um empreendimento.

\subsubsection{Conceito e Tipos de Alianças Estratégicas}

Os executivos devem aprender que a arte da competição e a da cooperação são igualmente válidas na estratégia corporativa. A cooperação e a competição promovem padrões alternativos ou simultâneos para o sucesso: alternativos, pois é possível atuar sozinho no mercado ou em parceria com outras empresas; e simultâneos, pois mesmo optando em estabelecer uma aliança a empresa continua competindo no mercado (CONTRACTOR; LORANGE, 1988).

Os autores citados acima ainda alegam ainda que a preferência tradicional dos executivos de empresas internacionais tem sido entrar em um mercado isoladamente; ou seja, tradicionalmente, os arranjos cooperativos estiveram como a segunda melhor opção estratégica. No entanto, esse panorama tem se alterado drasticamente nos últimos tempos, como é possível perceber pela ampla constituição de alianças e redes nos mais diversos setores. Já Sorensen e Reve (1998) alegam que as alianças estratégicas são modelos de organização usados pelas empresas para se posicionarem de maneira competitiva. São arranjos entre empresas que se relacionam, visando a obtenção de vantagem competitiva sustentável para os participantes. 
Assim, alianças e parcerias podem ser consideradas conceitos análogos segundo esta última definição. Já quanto às configurações estruturais, as alianças estratégicas podem assumir distintas formas, com distintas gradações de integração vertical (LORANGE; ROSS, 1996). Na Figura 3 apresentam-se as opções de alianças estratégicas e o grau de integração vertical dos parceiros com a empresa-mãe, tendo como extremos, de um lado, as fusões e aquisições, entidades com enfoque elevado na integração vertical e alta formalização; e, de outro, as relações comerciais usuais de compra e venda, as quais não envolvem qualquer tipo de compartilhamento de propriedade e investimentos conjuntos, apresentam baixa formalização em geral, exceto quando são regidas por contratos de compra e venda.

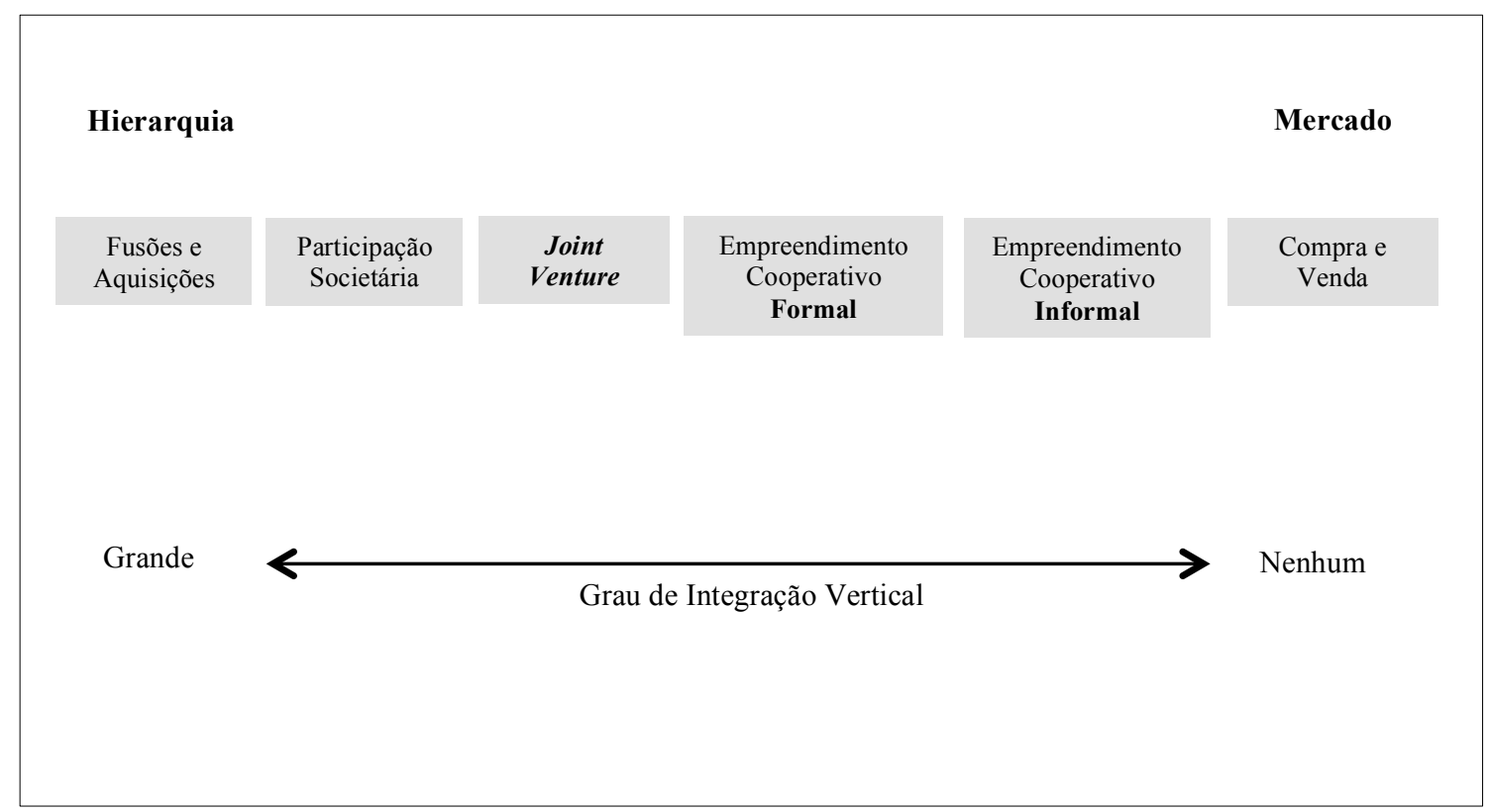

Figura 3 - Opções estruturais de Alianças Estratégicas Fonte: Adaptado de Lorange e Ross (1996).

Nesse espectro amplo proposto por Lorange e Ross (1996), torna-se didático explorar as subcategorias existentes nos acordos, em diferentes composições em termos de agentes e objetivos da aliança.

Nesse sentido, Pekar e Allio (1994) apresentam uma tipologia específica detalhada para as alianças estratégicas, categorizada no Quadro 1, no que tange aos tipos de acordos possíveis de serem estabelecidos. 
Quadro 1 - Diferentes tipos de alianças estratégicas

\begin{tabular}{|c|c|}
\hline Tipos de Alianças & Exemplos específicos \\
\hline Propaganda colaborativa & $\begin{array}{l}\text { American Express e Toys R Us, em esforço cooperativo em } \\
\text { propagandas em comerciais de TV e promoções conjuntas }\end{array}$ \\
\hline Parcerias de P\&D & $\begin{array}{l}\text { Cytel e Sumitomo Chemicals, para o desenvolvimento de nova geração } \\
\text { de drogas biotecnológicas }\end{array}$ \\
\hline $\begin{array}{l}\text { Acordos de serviços de } \\
\text { financiamentos }\end{array}$ & $\begin{array}{l}\text { Cigna e United Motor Works, para concessão de financiamentos a } \\
\text { empresas não norte-americanas e governos }\end{array}$ \\
\hline Distribuição compartilhada & $\begin{array}{l}\text { Nissan e Volkswagen (cada qual vende o automóvel do outro em seu } \\
\text { Continente) }\end{array}$ \\
\hline Transferência tecnológica & $\begin{array}{l}\text { IBM e Apple na cooperação para o desenvolvimento de nova geração } \\
\text { de softwares de sistemas operacionais }\end{array}$ \\
\hline Ofertas cooperadas & $\begin{array}{l}\text { Boeing, General Dynamics e Lockheed cooperando em proposta para } \\
\text { ganhar contrato da ataques táticos avançados, junto ao governo norte- } \\
\text { americano }\end{array}$ \\
\hline Manufatura cruzada & $\begin{array}{l}\text { Ford e Mazda, em projeto e construção de carros similares na mesma } \\
\text { linha de montagem }\end{array}$ \\
\hline $\begin{array}{l}\text { Novo empreendimento com } \\
\text { compartilhamento de } \\
\text { recursos }\end{array}$ & $\begin{array}{l}\text { Swift Chemical Co, Texas Gulf, RTZ e US Bórax em empreendimento } \\
\text { de mineração canadense com compartilhamento de recursos }\end{array}$ \\
\hline $\begin{array}{l}\text { Parcerias Governo- } \\
\text { Indústria }\end{array}$ & $\begin{array}{l}\text { Du Pont e National Cancer Institute, na primeira fase de teste de droga } \\
\text { contra o câncer }\end{array}$ \\
\hline Spin-Offs internos & $\begin{array}{l}\text { Motores Cummins e Toshiba Corporation, criando nova empresa para } \\
\text { desenvolvimento e comercialização de produtos à base de silício }\end{array}$ \\
\hline Licenciamento cruzado & $\begin{array}{l}\text { Acordo da Hoffman-La Roche e Glaxo, para a primeira vender o } \\
\text { Zantac, droga antiúlcera, nos Estados Unidos, através da segunda }\end{array}$ \\
\hline
\end{tabular}

Fonte: PEKAR; ALLIO, 1994, p. 56.

Há também a classificação de Adobor (2006), baseada nas motivações para as alianças, chamadas por ele de origens, que permitem perceber mais facilmente a dinâmica crucial envolvida, como, por exemplo, políticas públicas de governos que criam estímulos para a constituição de determinada aliança. 
Quadro 2 - Categoria da aliança versus teoria dominante

\begin{tabular}{|c|c|c|c|c|}
\hline $\begin{array}{l}\text { Origem da } \\
\text { aliança }\end{array}$ & $\begin{array}{l}\text { Forma de } \\
\text { governança } \\
\text { dominante }\end{array}$ & $\begin{array}{l}\text { Estrutura de } \\
\text { propriedade } \\
\text { dominante }\end{array}$ & Exemplos & $\begin{array}{l}\text { Âncora teórica } \\
\text { dominante }\end{array}$ \\
\hline $\begin{array}{l}\text { Cooperação } \\
\text { "forçada" por } \\
\text { uma terceira } \\
\text { parte }\end{array}$ & Contratos & $\begin{array}{l}\text { Arranjos com } \\
\text { participações } \\
\text { distribuídas } \\
\text { (ex. Joint } \\
\text { ventures) }\end{array}$ & $\begin{array}{l}\text { Mc Donald Douglas na } \\
\text { China (Haldick, 1988) }\end{array}$ & $\begin{array}{l}\text { Teoria dos custos } \\
\text { de transação } \\
\text { (Willianson, 1985) } \\
\text { Teoria dos jogos } \\
\text { (Axelrod, 1984) }\end{array}$ \\
\hline $\begin{array}{l}\text { Cooperação } \\
\text { orquestrada } \\
\text { ou facilitada } \\
\text { por um } \\
\text { intermediário }\end{array}$ & $\begin{array}{c}\text { Interdependência, } \\
\text { confiança } \\
\text { institucional e } \\
\text { controle }\end{array}$ & $\begin{array}{l}\text { Formas de } \\
\text { redes de } \\
\text { cooperação }\end{array}$ & $\begin{array}{c}\text { SEMATECH, The } \\
\text { software engineering } \\
\text { institute, The natural } \\
\text { center for manufacturing } \\
\text { science (Breyer, Shelter e } \\
\text { Browning, 1995; Similor, } \\
\text { 1992) Airbus, Governos } \\
\text { países europeus (Tucker, } \\
\text { 1991); }\end{array}$ & $\begin{array}{c}\text { Teoria de redes } \\
\text { (Ibarra, Husted) } \\
\text { Teoria } \\
\text { Institucional, Di } \\
\text { Maggio e Powell } \\
\text { 1983) }\end{array}$ \\
\hline $\begin{array}{l}\text { Cooperação } \\
\text { iniciada entre } \\
\text { firmas } \\
\text { individuais }\end{array}$ & $\begin{array}{l}\text { Considerações } \\
\text { relacionais } \\
\text { (controle ou } \\
\text { confiança } \\
\text { dependendo dos } \\
\text { atores) }\end{array}$ & $\begin{array}{l}\text { Alianças com } \\
\text { participação, } \\
\text { alianças sem } \\
\text { participação, } \\
\text { alianças } \\
\text { horizontais }\end{array}$ & $\begin{array}{c}\text { NUMMI (GM e Toyota } \\
\text { Motors); FujiXerox (Fuji } \\
\text { e Xerox); Dow Corning } \\
\text { (Dow Chemical e Corning } \\
\text { Glass) }\end{array}$ & $\begin{array}{l}\text { Teoria relacional } \\
\text { (Anderson e } \\
\text { Narus, 1990; Dyer } \\
\text { e Singh, 1988) }\end{array}$ \\
\hline $\begin{array}{l}\text { Cooperação } \\
\text { espontânea } \\
\text { ou de } \\
\text { ocorrência } \\
\text { natural }\end{array}$ & $\begin{array}{l}\text { Alta confiança } \\
\text { Normas } \\
\text { compartilhadas } \\
\text { Controle } \\
\text { institucional }\end{array}$ & $\begin{array}{c}\text { Redes, alianças } \\
\text { sem } \\
\text { participação } \\
\text { acionária, } \\
\text { cooperações } \\
\text { informais. }\end{array}$ & $\begin{array}{l}\text { Várias formas de ligações } \\
\text { interfirmas, no Vale do } \\
\text { Silício (Saxenian, 1994) e } \\
\text { em Modena na Itália } \\
\text { (Piore e Sabel, 1984) }\end{array}$ & $\begin{array}{c}\text { Geografia } \\
\text { econômica (Sabel, } \\
\text { 1991) Teorias de } \\
\text { macroculturas } \\
\text { (Abrahamsom e } \\
\text { Fonbrum, 1994) }\end{array}$ \\
\hline
\end{tabular}

Fonte: ADOBOR, 2006, p. 122.

O Quadro 2 apresenta as quatro categorias sugeridas por ele, contendo a origem, governança, propriedade, exemplos na prática e teorias dominantes associadas. A primeira categoria, a cooperação forçada por uma terceira parte, em geral materializa-se como as joint ventures e tem sua dinâmica descrita pelas obrigações legais a que uma empresa tem que se submeter ao adentrar em um novo mercado, como, por exemplo, a exigência do governo chinês de que empresas multinacionais constituam nova estrutura 
jurídica em aliança com empresas locais ao se instalar naquele território. A segunda categoria, cooperação orquestrada ou facilitada por um intermediário, possui como estrutura de propriedade dominante redes de cooperação. Neste estudo, esses tipos de aliança não serão abordados, pois envolvem participação acionária ou participação de terceiros e essas configurações já se encontram bem descritas pela literatura concernente às alianças estratégicas.

A terceira categoria, cooperação iniciada entre firmas individuais por meio da qual as empresas buscam alcançar seus objetivos de criação de vantagem competitiva, é o tipo mais frequente, em todo o mundo, de utilização de alianças (ADOBOR, 2006) e pode envolver alianças com ou sem participação acionária entre empresas, mas sem a imposição de uma terceira parte. Neste estudo, restringir-nos-emos às alianças sem participação acionária desta categoria e da anterior. Por fim, a quarta categoria, alianças espontâneas de ocorrência natural, é de natureza informal e deriva da existência de condições habilitadoras, como proximidade geográfica, percepção comum das ameaças e oportunidades coletivas, e de normas sociais compartilhadas no entorno, que favorecem a cooperação. Nesta categoria se enquadraria a maior parte das cooperações em clusters, arranjos produtivos locais, parques e polos tecnológicos.

Klotze (2001), conforme ilustrado na Figura 4, foca o tipo de governança e propriedade envolvidas na aliança, portanto aparenta melhor organização que a tipologia anterior, pois simplifica com apenas quatro classificações principais (contratos unilaterais, participação acionária minoritária, joint ventures e contratos bilaterais), nas quais se inclui a maior parte dos tipos específicos identificados na tipologia de Pekar e Allio (1994). 


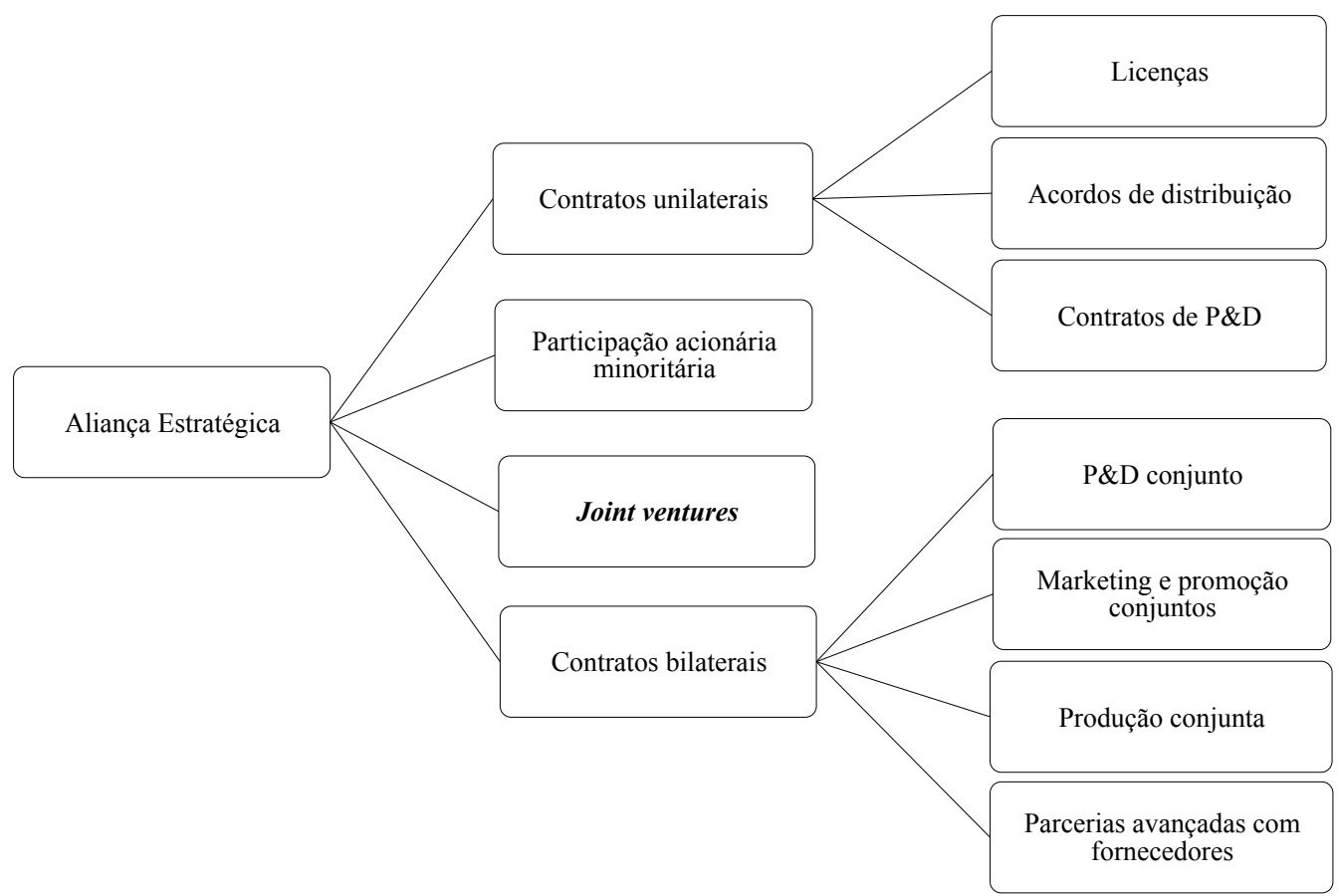

Figura 4 - Tipos de Alianças Estratégicas Fonte: KLOTZE, 2001.

Deve-se tomar precauções no uso de classificações, embora sua utilidade tenha sido destacada. Isso porque as classificações existentes podem focalizar apenas as formas cooperativas formais, as quais pressupõem o estabelecimento de um acordo explícito formalizado entre os parceiros; os acordos informais, porém, vêm crescendo em um ritmo bastante elevado nos dias atuais.

As duas categorias mais populares são alianças com participação acionária e alianças sem participação acionária. Alianças com participação acionária envolvem relações em que ambos os parceiros possuem um objetivo comum que é normalmente expresso por investimentos conjuntos (HENNART apud ADOBOR, 2006). Por outro lado, as alianças sem participação acionária tratam de relações nas quais pode não haver investimentos conjuntos.

As alianças também têm sido classificadas quanto à localização geográfica e ao escopo político, quando podem assumir a condição de aliança doméstica, quando os parceiros são do mesmo país, ou internacional, quando envolvem parceiros de diferentes países. Mais do que detalhar todas as possibilidades de cooperação e seus motivos específicos, para o propósito deste estudo parece razoável restringirmo-nos às categorizações que 
envolvam os aspectos fundamentais, o que parece ser o caso da classificação de Klotze (2001), tratando as propriedades e a governança da aliança como qualificadores principais. Como exposto, a classificação utilizando esses aspectos é a mais frequente na literatura.

\subsection{Teoria sobre Riscos Corporativos}

Segundo Ramos (2000), as empresas existem para oferecer produtos ou serviços à sociedade; para fazer isso, uma empresa investe capital, assume um número de riscos e, pelo gerenciamento efetivo desses riscos, tem capacidade para obter lucro. Desde essa perspectiva, a gestão do risco é uma parte fundamental e estratégica no processo de tomada de decisões de uma empresa e, por conseguinte, contribui para a criação do valor em todos os níveis da organização e em especial para o stakeholder.

O processo de gestão numa empresa implica tomada de decisões estratégicas - investimento e financiamento -, as quais são tomadas em condições de risco, ou seja, norteadas por expectativas e projeções que, em razão de uma diversidade de fatores ou variáveis, podem não ocorrer, gerando consequências diversas, desde a queda de rentabilidade da empresa ou de suas ações, até eventuais desastres financeiros, como processos de falência.

Assim, pode-se concluir que o gerenciamento de riscos é justamente um conjunto de processos proativos que são acionados para identificar e analisar riscos e executar ações, com o objetivo de eliminar ou minimizar os problemas antes que ocorram e, consequentemente, aumentar a probabilidade de ganho para a empresa.

A gestão de riscos corporativos é foco de preocupação tanto em empresas com objetivos e metas financeiras, como em instituições com fins ideais, isto é, sem metas ou objetivos financeiros. Esta parte destaca o gerenciamento de riscos em empresas não financeiras.

Os procedimentos para o gerenciamento de riscos em empresas não financeiras são: determinação dos objetivos em termos de risco; mapeamento dos riscos relevantes e a 
estimativa de sua magnitude presente e futura; definição de instrumentos para o gerenciamento do risco; construção e implantação de uma estratégia para tratar o risco; avaliação do desempenho do gerenciamento de risco (CROUHY; GALAY; MARK (2004, p. 17).

O Enterprise Risk Management (ERM) é conceituado conforme segue: um processo afetado por um conselho de diretores de gestão e outro conselho pessoal, aplicado à definição de estratégia em toda a empresa e projetado para identificar eventos potenciais que possam interferir na entidade e gerir riscos, para fornecer garantia razoável à realização dos objetivos da entidade (COSO, 2004).

Para Ferraz (2003), o gerenciamento de riscos é necessário primeiramente para a geração do valor de uma empresa e, em um segundo momento, para sua manutenção, pois os resultados advindos da gestão de riscos acarretam aumento nos valores esperados dos fluxos de caixa futuros e, por extensão, na redução do custo médio do capital.

Já a norma ISO (International Organization for Standartization) 31000 visa a adoção de procedimentos para generalizar a gestão de riscos independentemente do tipo, tamanho e área de atuação de uma empresa. Em um primeiro momento, parece que o COSO e a ISO se aproximam e se completam.

\subsubsection{ISO 31000 e COSO}

A partir da criação da norma ISO 31000 (2009), nominada como Diretrizes Gerais para Implementação de Princípios e de Gestão de Risco, foi possível generalizar a gestão de risco independentemente do tipo, tamanho e área de atuação da organização, pois a norma concebe procedimentos que, em seu conjunto, englobam os diferentes conceitos de gestão de riscos. Seu objetivo é lidar com a incerteza que pode afetar os objetivos empresariais (KRÓLAS; KRÓLAS, 2010; LUND; SOLHAUG; STOLEN, 2010).

A norma COSO (Comitê de Organizações Patrocinadoras da Treadway), que estabelece procedimentos de controle interno, definidos como a elaboração e aplicação de 
processos que possam garantir, com razoável grau de certeza, que os objetivos colimados pela empresa ou instituição sejam alcançados. A técnica COSO guarda várias semelhanças com a norma ISO 31000 (2009), embora, ao mesmo tempo, também apresente sensíveis diferenças em relação a ela.

Diferentemente, a meta proposta pela norma ISO 31000 (2009) é investigar racionalmente quem está sendo cobrado para alcançar a eficiência e a eficácia operacional. O resultado do trabalho desses elementos apontados na norma ISO 31000 (2009) está fortemente relacionado com os objetivos básicos da empresa ou entidade, dentre os quais: os objetivos e metas de desempenho e rentabilidade, a segurança dos elementos humanos e dos meios operacionais e a qualidade dos ativos. Portanto, o objetivo básico, pretendido com a criação da norma ISO 31000 (2009), foi dotar os gestores de uma ferramenta genérica para o gerenciamento de riscos.

Ela é aplicável em qualquer tipo de organização, independentemente do tamanho e ramo de atividade. Sua metodologia visa identificar e analisar os riscos e os cenários que serão enfrentados. A norma pode ser aplicada a vários tipos de riscos, por exemplo: financeiro, operacional, de saúde, de projeto, de meio ambiente, de informação, de segurança empresarial, entre outros. A norma serve para fazer com que as empresas não tratem os riscos de forma isolada, mas sim com um estudo de impactos cruzados entre as diversas áreas da organização.

Estas normas - tanto o COSO como a ISO 31000 (2009) - exigem que se tenha total confiança nos registros contábeis e financeiros, pois todas as transações devem ser registradas e todos os registros devem refletir transações reais, consignadas pelos valores e enquadramentos corretos. A entidade também deve manter conformidade com as leis e normativos aplicáveis à entidade e a sua área de atuação. Assim, o Controle Interno é visto pelo COSO como um processo integrado e coordenado, que pode ser constituído por cinco (COSO, 2013), sete (COSO, 2004) ou até oito (COSO, 2007) componentes do gerenciamento de riscos corporativos inter-relacionados entre si.

Optou-se por apresentar os elementos do COSO (2007): ambiente interno; fixação de 
objetivos; identificação de eventos; avaliação de gerenciamento de riscos; resposta ao risco; atividade de controle; informação e comunicação; e monitoramento. Cabe salientar que do sumário executivo de 2004 para o de 2007 houve a explicitação do elemento identificação de eventos; e do sumário executivo de 2007 para o de 2013, os cinco primeiros elementos foram substituídos por dois elementos que os agrupam: ambiente de controle e avaliação de riscos.

A fim de se abrangerem efeitos teóricos, apresentam-se sucintamente os oito componentes inter-relacionados, mencionados no sumário de 2007, ilustrados na Figura 5 , por se crer que estão mais completos em relação à proposta do COSO:

I. Ambiente interno: algumas vezes também designado por Contexto Interno, é a parte da estrutura organizacional dentro da qual a entidade busca atingir seus objetivos. Também já foi denominado de a consciência do controle da entidade, pois é em sua cultura que se originam as necessidades de controle. $\mathrm{O}$ ambiente de controle é efetivo quando os elementos humanos inseridos na entidade sabem quais são suas responsabilidades, os exatos limites de sua autoridade, e agem de acordo com os ditames de suas consciências, mantendo a competência e o comprometimento de realizar apenas o que é correto e da maneira correta. Dentro do ambiente interno, a postura da alta administração também desempenha um papel determinante, pois é ela quem deve deixar claro para seus colaboradores quais são as políticas, os procedimentos, o código de ética e as condutas a serem adotadas. As funções principais do controle interno estão relacionadas ao cumprimento dos objetivos da entidade. Portanto, a existência de objetivos e metas é essencial para a existência dos controles internos.

II. Fixação de objetivos: Uma administração racional deve avaliar os eventos futuros com base em duas perspectivas: probabilidade de ocorrência e impacto na entidade, em seus clientes, seus colaboradores e fornecedores. A avaliação de riscos permite que uma organização considere até que ponto os eventos futuros, em potencial, podem impactar a realização dos objetivos. Quase sempre a avaliação utiliza uma combinação de métodos qualitativos e quantitativos, e impactos positivos e negativos dos eventos em potencial devem 
ser analisados isoladamente ou por categoria em toda a organização. Os riscos devem ser avaliados em suas características inerentes e residuais.

III. Identificação de eventos: A gestão deve mapear e identificar os eventos em potencial, internos e externos, que podem, de alguma forma, influenciar o alcance dos objetivos da organização, sejam esses eventos positivos (oportunidades) ou negativos (ameaças). A identificação desses eventos deve orientar os processos de estabelecimento de estratégias de ação ou mesmo de revisão de objetivos organizacionais.

IV. Avaliação de gerenciamento de riscos: A norma ISO 31000 (2009) define a avaliação de risco como o processo de comparar os resultados da análise de riscos com os critérios adotados para definir os riscos. Sendo o risco inerente a todo processo de planejamento (KOSIOL, 1967), o gerenciamento de riscos deve se constituir em um processo contínuo, fluindo através de toda a organização. O processo de gerenciamento de riscos deverá ser incluído na delimitação e definição das estratégias da entidade, e ser conduzido por profissionais qualificados e treinados em todos os níveis da organização. Agindo dessa forma, a entidade forma uma visão de portfólio de todos os riscos a que está exposta. O gerenciamento dos riscos é formulado para identificar eventos em potencial, cuja ocorrência poderá afetar a organização, bem como para administrar os riscos de acordo com o apetite ao risco da entidade. Assim sendo, esse gerenciamento é capaz de propiciar uma garantia razoável ao conselho de administração e à diretoria executiva de uma organização. $O$ gerenciamento do risco é então orientado para a realização dos objetivos em uma ou mais categorias distintas, mas dependentes.

V. Resposta ao risco: A norma ISO 31000 (2009) denomina a resposta ao risco de tratamento dos riscos. Aceitando-se a proposição de Erich Kosiol (1967), segundo a qual o risco é inerente a todo processo de planejamento, a administração deve determinar claramente de que forma a entidade responderá aos riscos previstos ou encontrados. Assim, são reconhecidas quatro diferentes posturas: evitar, reduzir, compartilhar ou aceitar. Ao considerar a própria resposta, a administração avalia a probabilidade de ocorrência do risco e os impactos que daí poderão advir. Dessa forma, é possível selecionar os rumos 
de ação que manterão os riscos residuais dentro dos níveis de risco toleráveis. A administração também deve identificar as oportunidades que possam existir, para, dessa forma, obter uma visão panorâmica dos riscos em toda a organização.

VI. Atividade de controle: Para a norma ISO 31000 (2009), as atividades de controle - monitoramento dos riscos - devem garantir que os controles sejam eficazes e eficientes, tanto na fase de projeto como na fase operacional. Portanto, as atividades de controle englobam as políticas e os procedimentos que contribuem para assegurar que as respostas aos riscos sejam executadas. Essas atividades ocorrem em toda a organização, em todos os níveis e em todas as funções, pois compreendem uma série de ações diversas, como: aprovação, autorização, verificação, reconciliação, revisão do desempenho operacional, revisão da segurança dos bens e segregação das responsabilidades.

VII. Informação e comunicação: A norma ISO 31000 (2009) denomina este processo de comunicação contínua, vista como um processo bidirecional, de tal forma que as decisões bem informadas possam ser tomadas sobre o nível de riscos e sobre a necessidade de tratamento, de acordo com critérios de risco abrangentes e adequadamente estabelecidos.

VIII. Monitoramento: O monitoramento ocorre no decurso normal das atividades de administração. A função básica de um monitor é observar um processo ou uma sucessão de eventos e, a seguir, relatar o que observou aos gestores e responsáveis pelos controles internos. 


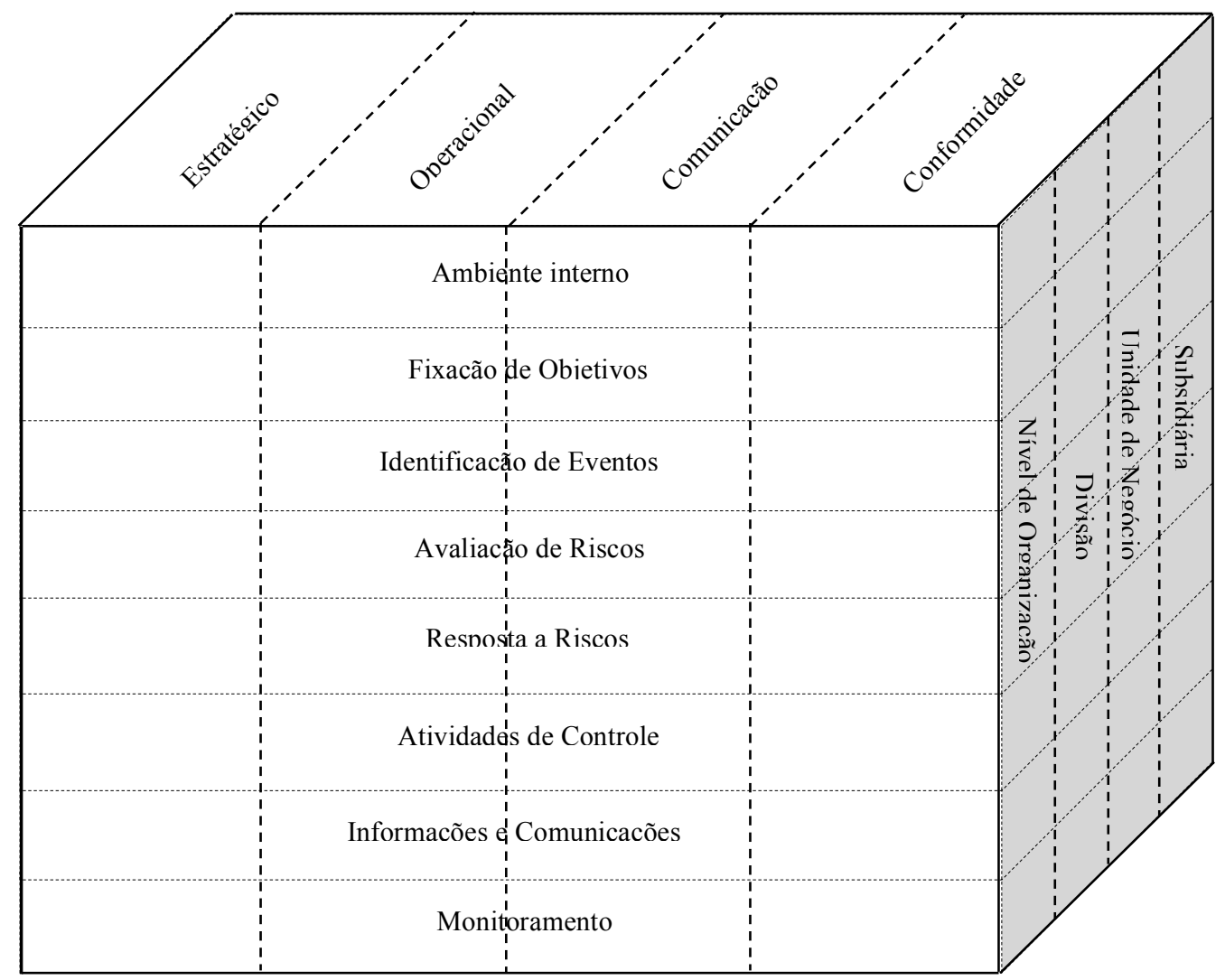

Figura 5 - Matriz tridimensional de relacionamento direto entre objetivos organizacionais e componentes do gerenciamento de riscos corporativos Fonte: COSO, 2007, p. 7.

Assim sendo, o COSO frisa que há um relacionamento direto entre esses componentes e os objetivos organizacionais, seja na categorização dos próprios objetivos, seja nos níveis de uma organização ou até mesmo em qualquer outro tipo de subunidade organizacional.

O COSO sugere quatro tipos de objetivos organizacionais: (a) estratégico: metas gerais alinhadas à missão; (b) operacional: utilização eficaz e eficiente dos recursos; (c) de comunicação: confiabilidade nos relatórios e informações; e (d) de conformidade: cumprimento de leis e regulamentos aplicáveis. Diante dessa matriz, o COSO considera que a "determinação do grau de eficácia do gerenciamento de riscos corporativos de uma organização corresponde ao julgamento decorrente da avaliação da presença e da eficácia do funcionamento dos oito elementos. Desse modo, os componentes também são critérios para o gerenciamento eficaz de riscos corporativos" (COSO, 2007, p. 7). 
Por sua vez, a norma ISO 31000 (2009) visualiza tais procedimentos nas formas que serão apresentadas a seguir. Ao descrevê-las, faz-se um paralelo com os procedimentos equivalentes, segundo o COSO:

i. Comunicação e consulta: Quando da aplicação do COSO e durante a operacionalização da norma ISO 31000 (2009), é importante desenvolver, logo no primeiro estágio do processo, um plano de comunicação com as partes internas e externas envolvidas. A comunicação envolve diálogo entre as partes, tendo como foco a consulta e não somente a comunicação de via única. A comunicação interna e externa eficaz é importante para que os responsáveis pela implantação da gestão de riscos e os investidores compreendam quais são as decisões tomadas e por que determinadas ações são necessárias.

ii. Contexto: Como o étimo faz antever, contexto é o ambiente no qual a organização está inserida, compreendendo os tipos: estratégico; organizacional; de gestão de riscos; de critérios (qual metodologia será utilizada); de estrutura e de variáveis incontroláveis.

iii. Identificação dos riscos e perigos: Um bom desenvolvimento do conteúdo deste ponto é extremamente importante para que se tenha uma visão efetiva dos riscos, bem como dos fatores que os originam. Para tanto, existe a necessidade de realizar uma avaliação das condições de segurança dentro da entidade, bem como dos fatores externos que poderão influir negativamente sobre ela. Após conhecer o contexto em que a organização está inserida, é possível definir quais riscos devem ser estudados. A identificação deve incluir todos os perigos, estando eles ou não sob o controle da Unidade de Negócio. O objetivo é gerar uma lista abrangente de eventos que possam afetar a organização. Após identificar os riscos, a organização deve identificar quais são seus fatores de risco.

iv. Análise de riscos: Destina-se a verificar o grau de criticidade dos riscos por meio de sua probabilidade de ocorrência e impacto na organização. Aqui, usam-se critérios prospectivos, pois os critérios projetivos não levam em conta o contexto atual em que a organização está inserida.

v. Avaliação de riscos: Destina-se a calcular o grau de probabilidade por meio da 
formula $\mathrm{GP}=$ fator de riscos $(\mathrm{FR}) \times$ exposição $(\mathrm{E})$. Após obter o Grau de Probabilidade e seu impacto, é possível criar uma matriz de vulnerabilidade para cada risco.

vi. Tratamento dos riscos: Apesar de existirem semelhanças entre as normas ISO 31000 (2009) e COSO - como a identificação de riscos x identificação de eventos; análise de riscos $\mathrm{x}$ avaliação de riscos -, para a norma ISO 31000 (2009) a empresa poderá, a depender do risco e a depender da avaliação e análise de seus gestores, reter, reduzir, transferir, explorar ou até mesmo evitar a comunicação dos riscos encontrados. A norma ISO 31000 (2009) tem um processo com foco principal no risco que afeta a empresa, com o objetivo de mitigá-lo, assumi-lo ou evitá-lo. Já a norma COSO tem um processo com foco principal no controle, para garantir a eficiência e eficácia do monitoramento das atividades que irão tratar os riscos.

vii. Monitoramento: No processo de monitoramento, a norma ISO 31000 (2009) cria procedimentos para acompanhar a execução de um Plano de Ação, verificando continuamente se as medidas adotadas estão surtindo o efeito desejado e observando o nível de riscos identificados por meio de seus fatores de riscos.

A Figura 6 a seguir ilustra o processo de Gestão de Riscos, proposto pela IS0 31000 (2009) supracitada. 


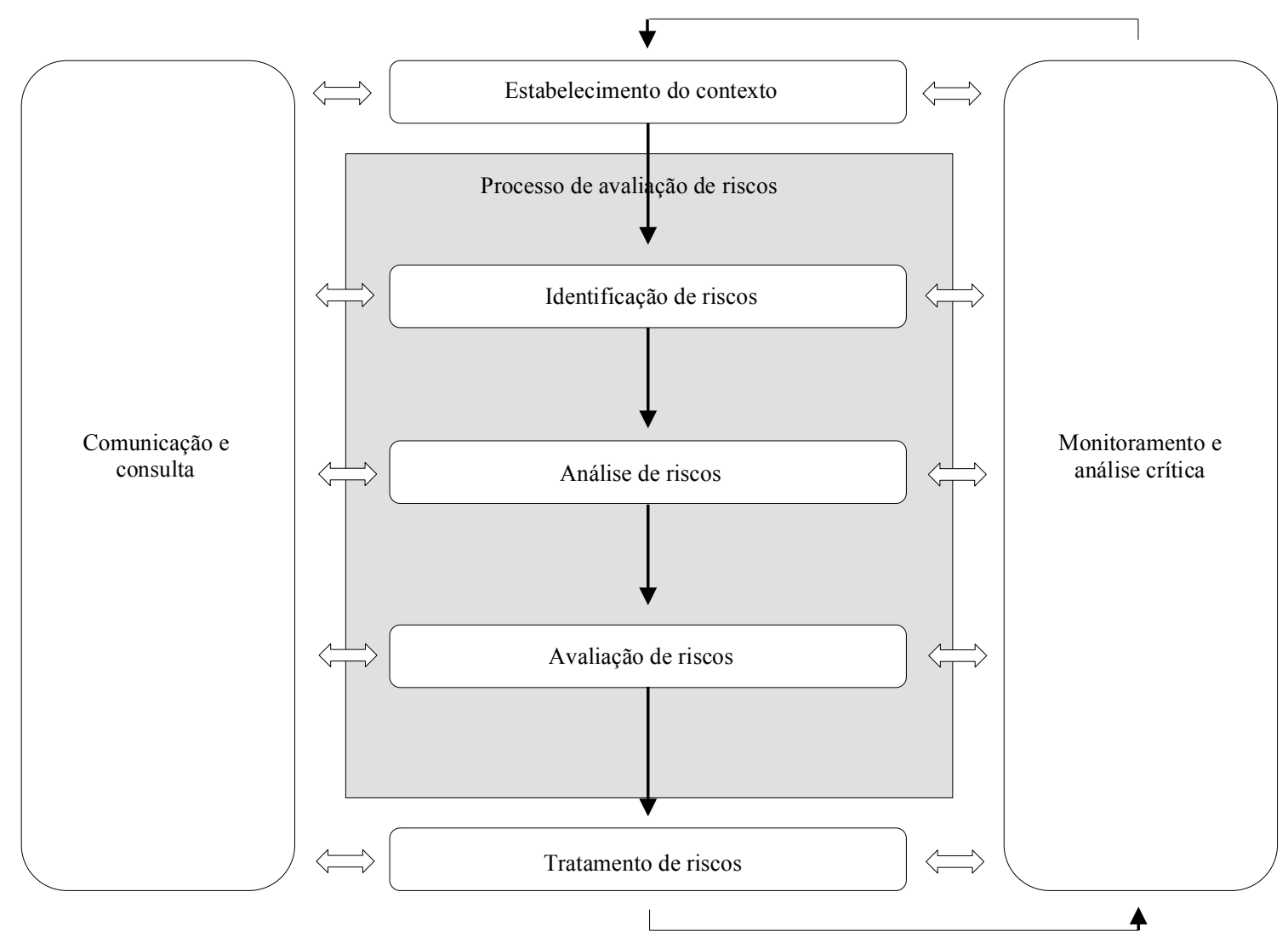

Figura 6 - Modelo de Gestão de Riscos

Fonte: ABNT NBR ISO 31000 (2009), 2009, p. 14.

Por fim, o processo de Gestão de Riscos, cujo sucesso está atrelado à eficácia da estrutura de gestão, adita os princípios e as configurações a serem seguidos por toda a organização, tanto de forma horizontal como de forma vertical. Em outras palavras, cabe à estrutura de gestão garantir que as informações a respeito de riscos sejam conduzidas aos órgãos competentes e às pessoas responsáveis pela tomada das decisões dentro da organização (ABNT NBR ISO 31000, 2009, p. 8).

\subsection{Teoria sobre gerenciamento de riscos corporativos}

Toda empresa opera no ambiente de negócios, que é composto de várias organizações e seus relacionamentos e divide-se em macroambiente e microambiente. $\mathrm{O}$ macroambiente inclui as forças que podem impactar o destino da empresa e que esta dificilmente consegue influenciar. Já o microambiente ou ambiente de valor consiste nos principais agentes que geram valor para a empresa, isto é, aqueles podem 
influenciar no destino da empresa, mas também podem ser mais efetivamente influenciados pela empresa; e as forças ambientais no microambiente manifestam-se pelo poder de negociação, oportunismo, inovação e estratégia de seus agentes (COASE, 1937, 1960, 2014; WILLIAMSON, 1975, 1991, 1996; DO NORTE, 1990; MENARD, 1995; PORTER, 2004, 2008; OLIVA, 2015).

O modelo proposto por Oliva (2015) avalia os riscos corporativos em três níveis: organização, ambiente de valor e ambiente de negócios, pois a organização está exposta às forças e eventos resultantes desses três ambientes e a análise deve transcender as fronteiras organizacionais, ou seja, deve-se considerar também as relações da organização, ou seja, da Gestiona, com outros agentes do ambiente de negócios, no caso, destacadamente, a aliança com a PwC. Os agentes são organizações que possuem uma relação importante com a empresa no que tange à manutenção ou criação de valor, ou seja, as organizações presentes no ambiente de valor da empresa. No modelo em questão os agentes considerados foram: a organização em si, clientes, fornecedores, concorrentes, distribuidores, governo e sociedade. Além disso, foi identificada a natureza dos riscos mais importantes associados para cada agente, conforme demonstra o Quadro 3.

Quadro 3 - Riscos corporativos no ambiente de valor

\begin{tabular}{|l|l|}
\hline \multicolumn{1}{|c|}{ Agentes } & \multicolumn{1}{c|}{ Riscos mais importantes } \\
\hline Organização & Estratégico, Operacional, Ético e Imagem \\
\hline Clientes & Social e Imagem \\
\hline Fornecedores & Estratégico, Operacional, Ético e Imagem \\
\hline Concorrentes & Financeiro, Inovação, Tecnológico, Ético e Imagem \\
\hline Distribuidores & Estratégico, Operacional, Ético e Imagem \\
\hline Governo & Econômico \\
\hline Sociedade & Sustentabilidade Ambiental e Meio Ambiente \\
\hline
\end{tabular}

Fonte: OLIVA, 2015, p. 17.

Os riscos empresariais devem ser analisados de forma sistemática, considerando a própria empresa e suas relações de valor em um ambiente de negócios com ameaças e oportunidades. Assim, como pode ser visto na Tabela 2, entende-se que os principais 
riscos decorrentes do ambiente de negócios são originados de eventos econômicos, políticos, sociais, tecnológicas e ambientais. Os riscos do ambiente de valor, em que a empresa sofre influência, mas também é um agente que influencia, são: financeiro, operacional, de imagem, sustentabilidade ambiental, ética, inovação e estratégica (COSO, 2004; ISO 31000 (2009), 2009; BALLOU, 2004; CHOPRA; SODJI, 2004; CHRISTOPHER; PECK, 2004; MANUJ; MENTZER, 2008; HILLSON, 1997; RIMS, 2006; OLIVA, 2015).

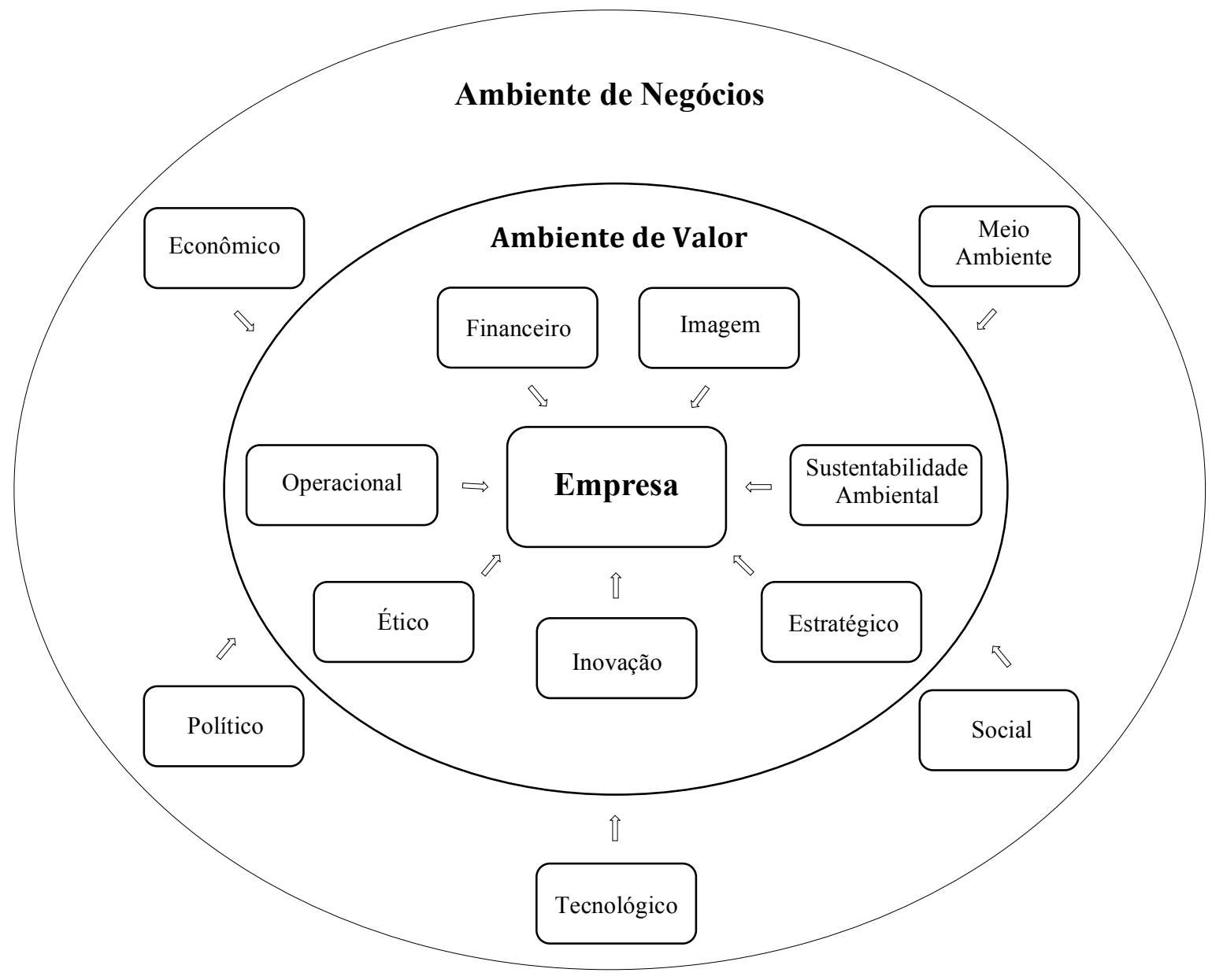

Figura 7 - Riscos corporativos no ambiente de valor Autor: OLIVA, 2014, p. 70.

O modelo de Oliva (2015) determina que as práticas de gestão de riscos corporativos podem ser classificadas em 4 fatores explicativos fundamentais, quais sejam: (i) organizacional: representa o quanto a empresa se esforça para produzir uma gestão de riscos estruturada; (ii) tecnicidade: retrata a frequência com que a empresa faz uso de 
técnicas qualitativas ou quantitativas para apoiar o processo de gestão de riscos na corporação; (iii) transparência: revela quantas vezes a empresa aborda o assunto abertamente com seus colaboradores, buscando envolvê-los na gestão participativa dos riscos corporativos; e (iv) envolvimento: mostra o quanto a empresa é capaz de envolver outros agentes do seu ambiente de valor para tornar sua gestão de risco mais eficiente e eficaz. A Figura 8 materializa os conceitos supracitados.

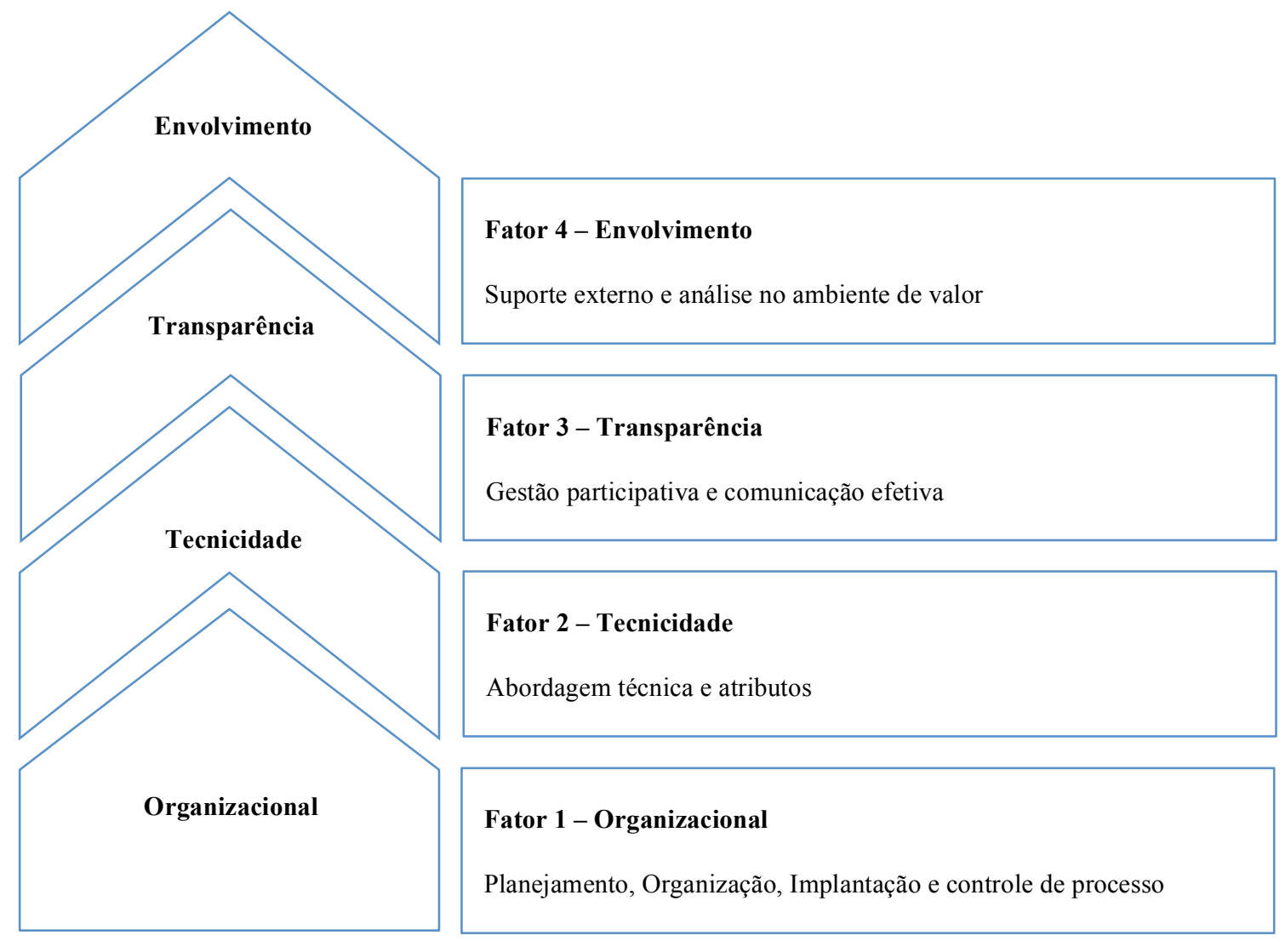

Figura 8 - Fatores explicativos da gestão de riscos corporativos Autor: OLIVA, 2014, p. 74.

Por fim, o modelo de maturidade na gestão de riscos corporativos proposto por Oliva (2015) define 5 níveis, descritos a seguir e estruturados na Figura 9, que resumem as características que devem estar presentes para que a organização seja considerada no respectivo nível de maturidade em gerenciamento de riscos.

Nível 1 - Gestão de Riscos Corporativos Insuficiente. Empresas que têm pouca consciência dos riscos corporativos. Não existe uma estrutura física ou conceitual 
dedicada aos riscos corporativos. A adoção de práticas de gestão de risco ocorre de forma não estruturada.

Nível 2 - Gestão de Riscos Corporativos Contingencial. Empresas que estão conscientes dos riscos a que estão sujeitas. Técnicas, ferramentas e métodos de gerenciamento de riscos são rudemente utilizadas. A gestão de risco é centralizada e caracterizada pelo baixo envolvimento dos funcionários em geral.

Nível 3 - Gestão de Riscos Corporativos Estruturada. Empresas com um maior grau de organização dos processos relacionados à gestão de riscos corporativos. Há um uso mais intenso das técnicas, ferramentas e métodos de gerenciamento de riscos.

Nível 4 - Gestão de Riscos Corporativos Participativa. Empresas com alto nível de consciência e organização no que diz respeito aos processos relacionados à gestão de riscos corporativos. A gestão de riscos é mais descentralizada. A comunicação é uma parte integrante e importante no risco de gestão. O gerenciamento de riscos corporativos é guiado pela participação da maioria dos funcionários.

Nível 5 - Gestão de Riscos Corporativos Sistêmica. Empresas neste nível têm gestão de riscos corporativos consciente, organizada e transparente. Utilizam apoio externo de firmas de consultoria, parceiros e institutos de pesquisa para melhorar a gestão de risco. Além disso, a empresa inclui cada vez mais a avaliação dos riscos do seu ambiente de valor na gestão de riscos, considerando que estes não respeitam as fronteiras organizacionais e são soberanos em relação aos limites da empresa. 


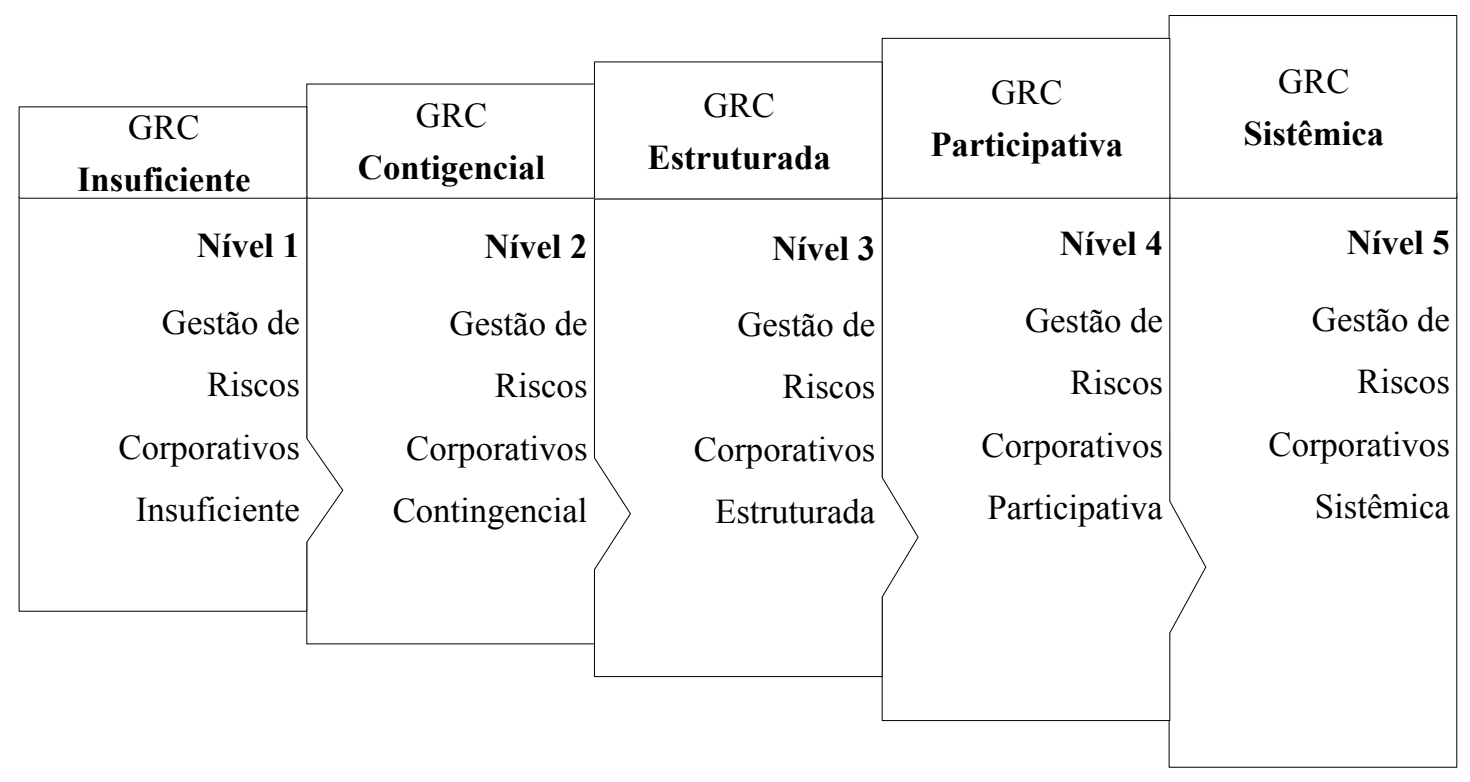

Figura 9 - Nível de maturidade na gestão de riscos corporativos Autor: OLIVA, 2014, p. 77.

\subsection{Teoria para análise de riscos corporativos em alianças estratégicas}

O modelo conceitual de gestão de alianças estratégicas de alta reciprocidade proposto por Bruno e Vasconcellos (1997) tem como objetivo analisar os motivos que levam os parceiros de uma aliança, com alto grau de envolvimento no empenho e nos resultados, a obter benefícios desproporcionais entre si ou impedem que os objetivos de um parceiro ou de ambos sejam alcançados.

O modelo fundamenta-se em dois conceitos-chave: estabilidade e efetividade das alianças, que por sua vez são analisadas em quatro dimensões: institucional, organizacional, execução e criação de valor, como pode ser visto na Figura 10. Vale ressaltar que o modelo é dinâmico, em razão da interação mutual das quatro dimensões e do fato de que estabilidade e efetividade são, por definição, suscetíveis a constantes mudanças de equilíbrio devidas à tensão entre cooperação e competição (BRUNO, 1995). 


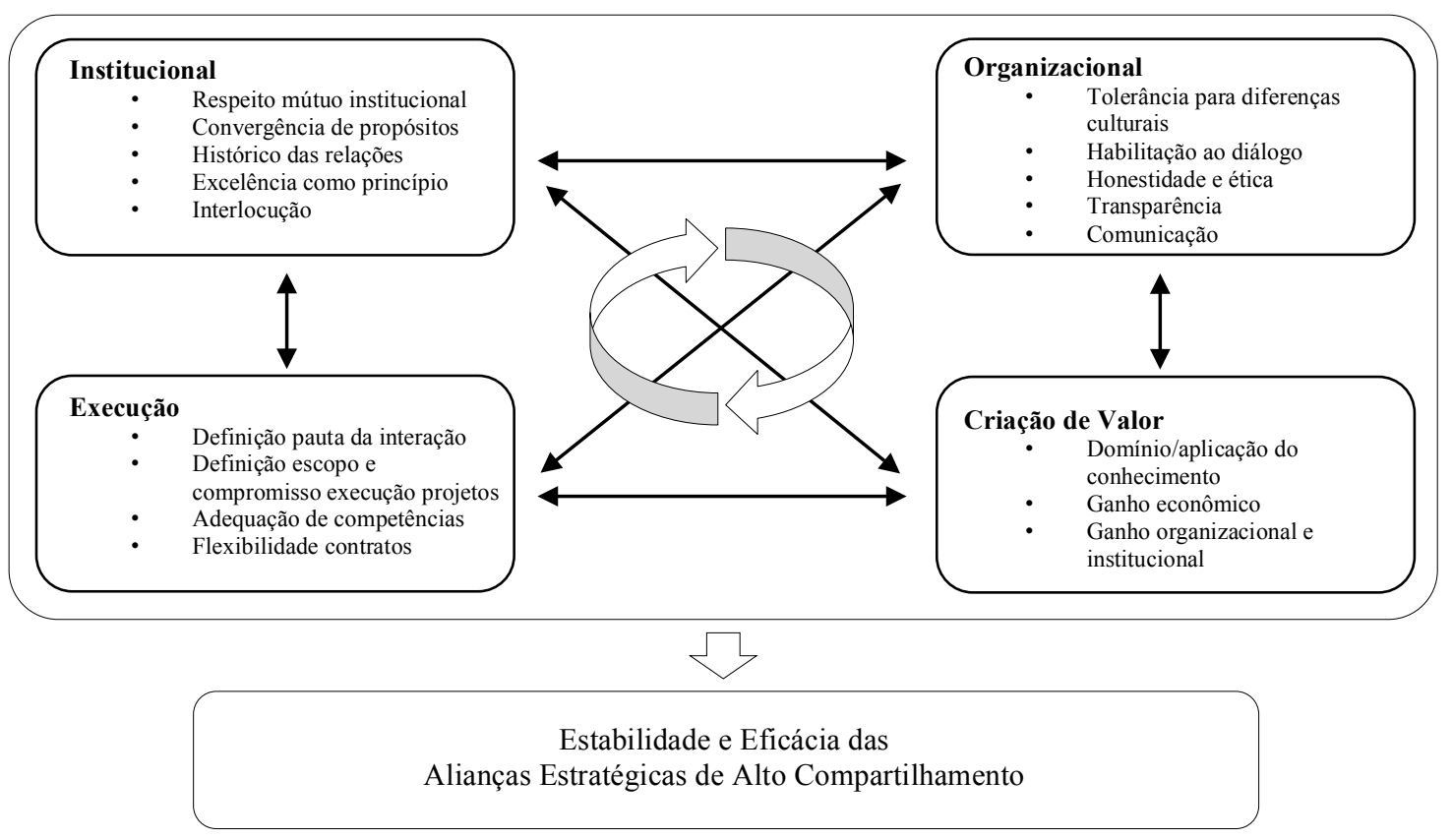

Figura 10 - Modelo para análise de estabilidade e eficácia em alianças de alto grau de compartilhamento

Fonte: BRUNO; VASCONCELLOS, 2003, p. 30. 



\section{METODOLOGIA DE PESQUISA}

Em face dos objetivos desta dissertação, quais sejam, identificar e analisar os riscos para a Gestiona envolvidos na aliança estratégica com a PwC, avaliar o nível de maturidade da Gestiona em gestão de riscos corporativos e também o nível de estabilidade e eficácia da aliança estratégica, e, por fim, propor uma estrutura de riscos a serem analisados antes e ao longo de uma aliança, este capítulo apresenta os procedimentos metodológicos para que os objetivos em questão sejam atingidos, divididos nas seguintes seções: (i) método, tipo e técnica de pesquisa; (ii) unidade de análise; (iii) tipo e coleta de dados; (iv) instrumento de pesquisa; e (v) tratamento e análise dos dados.

\subsection{Método, tipo e técnica de pesquisa}

Com o intuito de identificar, analisar e avaliar os riscos corporativos no processo de formação e durante a aliança estratégica entre a Gestiona e a $\mathrm{PwC}$, optou-se por um estudo de caso único. Segundo Yin (2010), uma justificativa para o caso único é quando ele representa o caso crítico no teste de uma teoria bem formulada. Uma segunda justificativa é quando ele representa um caso extremo ou peculiar, em que algum fenômeno raro chega a ser único e merece ser documentado e analisado. Além disso, as fontes de evidência mais comumente usadas na realização do estudo de caso são: documentação, registros em arquivos, entrevistas, observações diretas, observação participante e artefatos físicos (YIN, 2010).

Considerando a importância de definição do método, Gil (1999, p. 28) defende que os métodos podem ser classificados em dois grandes grupos: os que proporcionam as bases lógicas da investigação científica e os que esclarecem acerca dos procedimentos técnicos que poderão ser utilizados.

Diehl e Tatim (2004) também apresentam duas estratégias distintas: (1) a abordagem qualitativa, que se preocupa em compreender comportamentos em profundidade e busca o entendimento de particularidades de indivíduos ou de grupos sociais; e (2) a abordagem quantitativa, que se caracteriza pelo emprego da quantificação tanto nas 
modalidades de coleta de informações quanto em seu tratamento por meio de técnicas estatísticas (RICHARDSON, 1999, p.70).

Conforme conceitua HAIR (2005), esta pesquisa caracteriza-se como uma pesquisa exploratória, com vieses de pesquisa descritiva, em razão de sua natureza fundamentalmente qualitativa. Os vieses de pesquisa descritiva se sustentam porque se descreve o contexto da relação entre Gestiona e $\mathrm{PwC}$, cujos dados são essenciais para identificar e obter informações acerca dos riscos e demais características da aliança em questão.

Considerando-se a percepção de Richardson (1999) de que o método deve ser apropriado à natureza do problema a ser abordado, ao que se pretende investigar, tem-se que para esta dissertação, de modo geral, a abordagem e utilização do método qualitativo foi a escolha mais adequada. Menciona-se que, embora se utilizem dados quantitativos, ilustrados em tabelas, esses vieses são muito tímidos para se afirmar que também há a adoção do método quantitativo.

\subsection{Unidade de análise}

Tendo em vista o objetivo desta dissertação, que envolve a análise dos riscos corporativos envolvidos no processo de formação e durante a aliança estratégica entre Gestiona e PwC, o instrumento de pesquisa foi aplicado a seis participantes do processo de formação da aliança, três dos quais integrantes da Gestiona: o sócio-fundador (e autor), o diretor comercial e um consultor sênior; e três integrantes da PwC: um sócio sênior e sponsor da aliança, um diretor regional e um gerente sênior.

Vale lembrar que tal estudo de caso foi adaptado ao contexto do Mestrado Profissional em Empreendedorismo e, neste sentido, a participação do autor no processo em questão é condição sine qua non para obtenção objetivos pré-determinados para obteção do título de mestre em ciências. 


\subsection{Tipo e coleta de dados}

Os dados primários foram obtidos por meio de entrevistas semiestruturadas (COOPER; SHINDLER, 2013), e os dados secundários foram obtidos por meio de informações internas e publicações oficiais, começando pelo perfil dos entrevistados e organizacional, bem como do ambiente de valor no qual cada uma está inserida, além dos seus respectivos objetivos e componentes do gerenciamento de riscos corporativos (MARKONI; LAKATOS, 2010).

Com o intuito de minimizar o enviesamento por afinidade, optou-se por um entrevistador que não conhecia nenhum dos integrantes das empresas, exceto o sóciofundador da Gestiona, tampouco era integrante das empresas envolvidas e nem tivera qualquer participação ou conhecimento sobre o processo de formação da aliança estratégica entre Gestiona e PwC. A entrevista, se realizada por um investigador experiente, é muitas vezes superior a outros sistemas de obtenção de dados, afirma Best (1972, p. 120).

As entrevistas foram gravadas por um aparelho digital in loco, e todos os integrantes foram entrevistados com um intervalo aproximado de 15 meses, exceto o sócio sênior e sponsor da aliança na $\mathrm{PwC}$, que veio a falecer meses antes da segunda entrevista.

O objetivo da segunda rodada de entrevistas com esses mesmos integrantes das empresas foi capturar as variações de percepção de cada um em relação à aliança, pois, conforme Bruno (1995), estabilidade e efetividade são suscetíveis a constantes mudanças de equilíbrio em razão da tensão entre cooperação e competição.

Conforme recomendação de Gil (1999), para a condução da coleta de dados alguns procedimentos foram adotados: (i) preparação do roteiro de entrevistas; (ii) elaboração do instrumento de coleta (APÊNDICE 1); (iii) contato inicial; (iv) pré-teste com o entrevistador e um entrevistado; (v) busca de respostas completas; (vi) registro das respostas (gravação digital no caso); e (vii) conclusão da coleta.

Após cada entrevista os dados foram tratados e armazenados até a realização de todas as 
entrevistas, ou seja, duas vezes com cada participante, e, somente depois, consolidadas para então serem utilizadas na pesquisa.

\subsection{Instrumento de pesquisa}

Com o propósito de sustentar a análise da pesquisa, com base nos conceitos e teorias abordados na revisão da literatura, foi desenvolvida uma ferramenta de avaliação, utilizada para a construção do instrumento de coleta de dados. A fim de facilitar sua compreensão e alcançar os objetivos em questão, a ferramenta foi pautada no referencial teórico da dissertação e, nesse contexto, foram utilizados os seguintes constructos (EISENHARDT, 1989):
A. Ambiente de Valor;
B. Objetivos e componentes do gerenciamento de riscos corporativos;
C. Contexto da aliança estratégica;
D. Aliança estratégica de alto compartilhamento.

\section{A. Ambiente de Valor}

Para compreender o contexto em que cada empresa está inserida, faz-se necessária a caracterização do respectivo ambiente de valor, que conforme Oliva (2015) consiste nos principais agentes que geram valor para a empresa e que podem ser mais efetivamente influenciados por ela, quais sejam: clientes, fornecedores, distribuidores, concorrentes, governo e sociedade.
A1. Clientes
A2. Concorrentes
A3. Fornecedores
A4. Distribuidores
A5. Governo
A6. Sociedade

\section{B. Objetivos e componentes do gerenciamento de riscos corporativos}

A norma COSO (2007) estabeleceu, para o Controle Interno das organizações, oito componentes do gerenciamento de riscos corporativos: ambiente interno; fixação de 
objetivos; identificação de eventos; avaliação de gerenciamento de riscos; resposta ao risco; atividade de controle; informação e comunicação; e monitoramento.

B1. Ambiente interno

B2. Fixação de objetivos

B3. Identificação de eventos

B4. Avaliação de riscos

B5. Resposta ao risco

B6. Atividades de controle

B7. Informações e comunicações

B8. Monitoramento

\section{Contexto da aliança estratégica}

O modelo proposto por Oliva (2015) avalia os riscos corporativos em três níveis: organização, ambiente de valor e ambiente de negócios, pois a organização está exposta às forças e eventos resultantes desses três ambientes e a análise deve transcender as fronteiras organizacionais. Os principais riscos decorrentes do ambiente de negócios são originados a partir dos eventos econômicos, políticos, sociais, tecnológicos e ambientais. O ambiente de valor é formado pelos seguintes agentes: cliente, concorrente, fornecedor, distribuidor, governo e sociedade, além da empresa em si, que também é um agente que influencia e é influenciado pelos demais. Os riscos são: financeiro, operacional, imagem, sustentabilidade ambiental, ética, inovação e estratégico (BALLOU, 2004; CHORA; SODJI, 2004; CHRISTOPHER; PECK, 2004; MANUJ; MENTZER, 2008; HILLSON, 1997; RIMS, 2006; OLIVA, 2015).

C1. Motivação

C2. Natureza dos produtos/serviços

C3. Ambiente organizacional

- Estratégico

- Financeiro

- Operacional

- Imagem

- Ético

- Inovação 
- Sustentabilidade ambiental

C4. Ambiente de negócios

- Econômico

- Político

- Tecnológico

- Social

- Meio ambiente

\section{Aliança estratégica de alto compartilhamento}

O modelo conceitual de gestão de alianças estratégicas de alta reciprocidade proposto por Bruno e Vasconcellos (1997) fundamenta-se em dois conceitos-chave: estabilidade e efetividade das alianças, que por sua vez são analisados em quatro dimensões institucional, organizacional, execução e criação de valor.

D1. Institucional

D2. Organizacional

D3. Execução

D4. Criação de valor

\subsection{Tratamento e análise dos dados}

Quanto à análise dos dados, os modelos mais usados, segundo Yin (1989 apud Bressan, 2000), são: (1) padrão combinado - compara padrões com base empírica com os padrões previstos; (2) elaboração de explicações - o objetivo é analisar o estudo de caso para elaborar explicações sobre o caso e se constitui de uma acurada relação com os fatos do caso, considerações sobre as explicações alternativas e conclusões baseadas nas explicações que pareçam mais congruentes com os fatos; e (3) análise de séries temporais. Neste caso, foram utilizados os dois primeiros modelos.

Além disso, a análise e interpretação dos dados deu-se majoritariamente de forma qualitativa, pela análise documental e análise de conteúdo. A escala de Likert também se fez presente na coleta e tratamento dos dados. Além disso, também foi utilizada uma fórmula para mensuração do grau de criticidade (G.C.), considerando a probabilidade de ocorrência (P.O.) e o impacto para a organização (I.O.), sendo: G.C. = P.O. x I.O. 
Para garantir a triangulação, foi elaborada a matriz de validação (Quadro 4), que correlaciona: (i) objetivos geral e específicos; (ii) base conceitual; (iii) grupo de perguntas do instrumento de coleta de dados; e (iv) a forma de análise utilizada.

Quadro 4 - Resumo da relação entre objetivos, perguntas, teorias e análises

\begin{tabular}{|c|c|c|c|c|}
\hline \multicolumn{2}{|r|}{ Objetivos } & $\begin{array}{c}\text { Base Conceitual } \\
\text { (Conceitos, } \\
\text { Classificacões, Relacões }\end{array}$ & $\begin{array}{l}\text { Grupo de } \\
\text { perguntas } \\
\text { predomi- }\end{array}$ & $\begin{array}{l}\text { Análise Decorrente das } \\
\text { Respostas Suportada }\end{array}$ \\
\hline \multirow{5}{*}{ שֶ } & \multirow{5}{*}{$\begin{array}{l}\text { Análise da gestão de riscos } \\
\text { corporativos no processo } \\
\text { de formação e ao longo da } \\
\text { aliança estratégica entre a } \\
\text { Gestiona e a PwC }\end{array}$} & Aliança estratégica & \multirow{5}{*}{ Todos } & \multirow{5}{*}{$\begin{array}{l}\text { Identificar, analisar e } \\
\text { avaliar os riscos } \\
\text { corporativos envolvidos } \\
\text { na aliança e propor uma } \\
\text { estrutura para análise de } \\
\text { riscos antes da entrada e } \\
\text { ao longo da aliança } \\
\text { estratégica com base nas } \\
\text { respectivas teorias e } \\
\text { modelos }\end{array}$} \\
\hline & & $\begin{array}{l}\text { Gestão de Riscos } \\
\text { Corporativos }\end{array}$ & & \\
\hline & & ISO 31.000 & & \\
\hline & & COSO & & \\
\hline & & $\begin{array}{l}\text { Modelos Oliva (2015) e } \\
\text { Bruno e Vasconcellos } \\
\text { (1999) }\end{array}$ & & \\
\hline \multirow{5}{*}{ 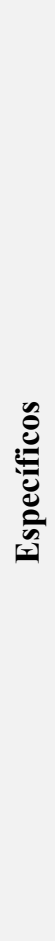 } & \multirow{3}{*}{$\begin{array}{l}\text { 1. Identificar os elementos } \\
\text { estruturais envolvidos na } \\
\text { Aliança Estratégica entre a } \\
\text { Gestiona e a PwC }\end{array}$} & Aliança estratégica & \multirow{3}{*}{$\begin{array}{c}\text { Grupos } \\
\text { B, C, D e E }\end{array}$} & \multirow{3}{*}{$\begin{array}{l}\text { Caracterizar as } \\
\text { características da aliança } \\
\text { relacionando os dados } \\
\text { apresentados com as } \\
\text { respectivas teorias }\end{array}$} \\
\hline & & $\begin{array}{l}\text { Gestão de riscos } \\
\text { corporativos }\end{array}$ & & \\
\hline & & ISO 31.000 e COSO & & \\
\hline & $\begin{array}{l}\text { 2. Identificar os riscos } \\
\text { corporativos para a } \\
\text { Gestiona no processo de } \\
\text { formação e ao longo da } \\
\text { aliança estratégica com a } \\
\text { PwC }\end{array}$ & $\begin{array}{l}\text { ISO 31.000; COSO } \\
\text { (2007); Modelos Oliva } \\
(2015) ; \text { e Bruno e } \\
\text { Vasconcellos (1999) }\end{array}$ & $\begin{array}{l}\text { Grupos } \\
\text { C, E e F }\end{array}$ & $\begin{array}{l}\text { Utilizar a categorização } \\
\text { das Teorias e Modelos } \\
\text { para identificar os Riscos } \\
\text { Corporativos envolvidos } \\
\text { na Aliança Estratégica }\end{array}$ \\
\hline & $\begin{array}{l}\text { 3. Analisar os riscos } \\
\text { corporativos para a } \\
\text { Gestiona no processo de } \\
\text { formação e ao longo da } \\
\text { aliança estratégica com a } \\
\text { PwC }\end{array}$ & $\begin{array}{l}\text { COSO (2007); Modelos } \\
\text { Oliva (2015); Bruno e } \\
\text { Vasconcellos (1999); } \\
\text { Maloni e Benton (1997); e } \\
\text { Das e Tent (1998) }\end{array}$ & $\begin{array}{l}\text { Grupo } \\
\text { D }\end{array}$ & $\begin{array}{l}\text { Utilizar as dimensões e } \\
\text { os conceitos das Teorias } \\
\text { e Modelos para analisar } \\
\text { os Riscos Corporativos e } \\
\text { os impactos para a } \\
\text { Gestiona }\end{array}$ \\
\hline
\end{tabular}




\begin{tabular}{|c|c|c|c|}
\hline $\begin{array}{l}\text { 4. Avaliar o nível de } \\
\text { maturidade da Gestiona } \\
\text { em gestão de riscos } \\
\text { corporativos. }\end{array}$ & $\begin{array}{l}\text { Modelo de Nível de } \\
\text { Maturidade na Gestão de } \\
\text { Riscos Corporativos } \\
\text { (Oliva, 2015) }\end{array}$ & $\underset{\mathrm{E}}{\text { Grupo }}$ & $\begin{array}{l}\text { Aplicar o modelo com } \\
\text { base nos riscos } \\
\text { identificados e } \\
\text { analisados, nos fatores } \\
\text { explicativos e nos níveis } \\
\text { de maturidade }\end{array}$ \\
\hline $\begin{array}{l}\text { 5. Avaliar o nível de } \\
\text { estabilidade e eficiência da } \\
\text { aliança estratégica entre } \\
\text { Gestiona e PwC }\end{array}$ & $\begin{array}{l}\text { Framework para análise } \\
\text { de riscos em alianças } \\
\text { estratégicas de Bruno e } \\
\text { Vasconcellos (1999). }\end{array}$ & $\begin{array}{l}\text { Grupos } \\
\text { D, E e F }\end{array}$ & $\begin{array}{l}\text { Aplicar o modelo } \\
\text { analisando a aliança com } \\
\text { base nas } 4 \text { dimensões } \\
\text { propostas e obter o nível } \\
\text { de estabilidade e } \\
\text { eficiência }\end{array}$ \\
\hline $\begin{array}{l}\text { 6. Propor uma estrutura de } \\
\text { riscos a serem analisados } \\
\text { nesse tipo de aliança } \\
\text { estratégica }\end{array}$ & $\begin{array}{l}\text { ISO 31.000; COSO } \\
\text { (2007); Modelo de GRC } \\
\text { Oliva, 2015) e Framework } \\
\text { Bruno e Vasconcellos } \\
\text { (1999). }\end{array}$ & $\begin{array}{c}\text { Grupos } \\
\text { C, D, E e F }\end{array}$ & $\begin{array}{l}\text { Criar um constructo } \\
\text { relacionando as } \\
\text { dimensões do ambiente } \\
\text { de negócios e os } \\
\text { principais riscos em } \\
\text { alianças estratégicas }\end{array}$ \\
\hline
\end{tabular}

Fonte: o autor.

Por fim, vale destacar que na descrição e análise dos dados, com o objetivo de não causar constrangimentos, optou-se por despersonalizar todos os comentários que não tivessem conexão com o propósito desta dissertação, e de forma a garantir o sigilo dos entrevistados. 


\section{APRESENTAÇÃO DOS DADOS}

Este capítulo apresenta as características de cada empresa envolvida na aliança estratégica em questão, considerando dados primários obtidos por meio de entrevistas semiestruturadas (COOPER; SHINDLER, 2013) e dados secundários obtidos por meio de informações internas e publicações oficiais, a começar pelo perfil dos entrevistados e pelo perfil organizacional, chegando ao ambiente de valor no qual cada uma está inserida, bem como aos seus respectivos objetivos e componentes do gerenciamento de riscos corporativos.

\subsection{Perfil dos entrevistados}

O instrumento de pesquisa foi aplicado a seis participantes do processo de formação de aliança estratégica entre Gestiona e Pwc Brasil, três dos quais integrantes da Gestiona: o sócio-fundador, o diretor comercial e um consultor sênior; e três integrantes da PwC Brasil - um sócio sênior, um diretor regional e um gerente sênior.

No que se refere à faixa etária, um entrevistado da Gestiona encontrava-se na faixa de 26 a 35 anos, outro de 46 a 55 anos e o terceiro de 56 a 65 anos. Já por parte da PwC Brasil, dois entrevistados estavam na faixa de 36 a 45 anos e um entrevistado na faixa de 56 a 65 anos. Quanto à formação acadêmica, dois integrantes da Gestiona possuíam curso superior completo, e o terceiro, curso de pós-graduação completo; quanto à PwC Brasil, todos possuíam curso de pós-graduação completo.

Por fim, quanto ao tempo de serviço na empresa e no cargo atual, no caso da Gestiona os tempos coincidem, pois não houve mudança de cargos: um integrante na faixa de 8 a 10 anos e dois integrantes na faixa de 2 a 4 anos. Quanto à PwC Brasil, no que tange ao tempo de serviço na empresa, temos um integrante na faixa de 16 anos ou mais e outros dois integrantes na faixa de 5 a 7 anos. Já no que se refere ao tempo de serviço no cargo atual, um integrante na faixa de 11 a 15 anos e dois integrantes na faixa de 2 a 4 anos. 


\subsection{Perfil das organizações}

A caracterização de cada empresa inicia-se com o ano de fundação e presença no Brasil, passa por um breve histórico que inclui setor de atuação e porte da empresa quanto ao número de empregados segundo a classificação SEBRAE (2015) e quanto à Receita Bruta Anual conforme critérios do BNDES (2015), além dos mercados atendidos e principais produtos e/ou serviços oferecidos.

\subsubsection{Gestiona}

A empresa foi fundada em 2004 na cidade de São Paulo e inicialmente foi constituída exclusivamente pelo sócio-fundador, que atuava como consultor independente e/ou sob a bandeira de outras consultorias (GESTIONA, 2015) no setor de serviços business-tobusiness (B2B), tendo como principal produto a prestação de serviços para utilização de incentivos fiscais à inovação tecnológica - conhecida como Capítulo III da Lei do Bem - para empresas de pequeno, médio e grande porte.

Atualmente, a Gestiona atua em todo o território nacional e enquadra-se como microempresa (até 19 empregados) segundo a classificação do SEBRAE (2015) para porte da empresa quanto ao número de funcionários, e empresa de pequeno porte (receita bruta anual maior que $\mathrm{R} \$ 2,4$ milhões e menor ou igual a $\mathrm{R} \$ 16$ milhões), conforme critérios do BNDES (2015).

\subsubsection{PwC Brasil}

A Price, que deu origem à PriwaterhouseCoopers, também chamada de $\mathrm{PwC}$, foi fundada em Londres em 1849, e é hoje uma das maiores prestadoras de serviços profissionais do mundo nas áreas de auditoria, consultoria e outros serviços acessórios para todo tipo de empresa e setor da economia. Presente em 157 países, possui mais de 223.000 funcionários e faturamento de US\$ 32,1 bilhões, em 2015. Presente no Brasil desde 1915, atualmente conta com cerca de 5.000 profissionais distribuídos em 16 escritórios ao longo do território nacional e faturamento superior a R\$ 1 bilhão em 2015 (PWC, 2016). Dessa forma, é classificada como grande empresa tanto em termos de empregados, conforme classificação do SEBRAE (2015), pois possui mais funcionários, 
como em termos de Receita Bruta Anual, segundo critérios do BNDES (2015), com cifra superior a R\$ 300 milhões.

Nota: PwC e PwC Brasil referem-se a marcas da PricewaterhouseCoopers International Limited que, ao longo desta dissertação, serão utilizadas de forma indiscriminada, mas sempre se referindo à $\mathrm{PwC}$ Brasil, objeto de estudo da aliança estratégica com a Gestiona.

\subsection{Ambiente de Valor}

Para compreender o contexto no qual cada empresa está inserida, faz-se necessária a caracterização do respectivo ambiente de valor, que, conforme Oliva (2015), consiste nos principais agentes que geram valor para a empresa e que podem ser mais efetivamente influenciados por ela, quais sejam: clientes, fornecedores, distribuidores, concorrentes, governo e sociedade.

\subsubsection{Gestiona}

Com base na consolidação das três entrevistas realizadas e na definição supracitada, o ambiente de valor da Gestiona foi organizado nos seis principais agentes envolvidos: clientes, fornecedores, distribuidores, concorrentes, governo e sociedade.

Clientes: principalmente médias (faturamento entre R\$ 16 milhões e R\$ 90 milhões), médias-grandes (faturamento entre $\mathrm{R} \$ 90$ milhões e $\mathrm{R} \$ 300$ milhões) e grandes empresas privadas (faturamento acima de $\mathrm{R} \$ 300$ milhões) de todos os segmentos da economia e de qualquer região do país.

Fornecedores: irrelevantes para a realização das atividades-fim, que são desenvolvidas e executadas exclusivamente pelos funcionários da Gestiona. No caso, resumem-se às atividades de apoio, como contabilidade, infraestrutura (energia elétrica, internet, servidores, etc.), manutenção de sites e e-mails, publicidade e atividades correlatas.

Distribuidores: na definição tradicional da cadeia produtiva, que compreende as operações de transporte e entrega (logística), não se aplicam à Gestiona, por envolverem serviços prestados diretamente aos clientes por meio de uma equipe de consultores. No 
entanto, no que tange ao conceito de canal de distribuição - interface entre empresa e cliente -, pode-se considerar os representantes comerciais, conhecidos no segmento de consultoria como finders, como sendo fundamentais para a captação de novos clientes, pois utilizam suas redes de contatos corporativos (network) para obterem a atenção das diretorias das empresas com potencial para a contratação dos serviços da Gestiona. Isso também é válido para os demais parceiros comerciais, tais como pequenas consultorias, escritórios de advocacia e também grandes empresas, como a PwC.

Concorrentes: Big Four (nomenclatura utilizada para as quatro maiores empresas contábeis especializadas em auditoria e consultoria do mundo: PricewaterhouseCoopers (PwC), antes da aliança estratégica, Deloitte Touche Tohmatsu (DTT), KPMG e Ernst \& Young (EY)), consultorias de médio porte oriundas de outros países, consultorias brasileiras de pequeno porte especializadas em incentivos fiscais à inovação tecnológica, além de alguns escritórios de direito tributário de pequeno e médio porte.

Governo: possui papel central nos principais serviços oferecidos pela Gestiona, que envolvem fundamentalmente incentivos fiscais e financiamento público subsidiado, pois, além do controle sobre as respectivas legislações, é o responsável pela análise e aprovação ou reprovação dos projetos apresentados.

Sociedade: a Gestiona impacta positivamente a sociedade na medida em que seus trabalhos tornam as empresas-clientes mais competitivas ao promover a PD\&I (Pesquisa, Desenvolvimento e Inovação) interna e a inovação aberta (open innovation), em parceria com centros de pesquisa e instituições de ciência e tecnologia, responsáveis pela concepção de novos produtos e processos que criam novos mercados e geram melhorias que aumentam a qualidade e a produtividade.

\subsubsection{PwC Brasil}

Assim como no caso da Gestiona, com base na consolidação das três entrevistas realizadas e na definição supracitada, o ambiente de valor da PwC Brasil foi organizado nos seis principais agentes envolvidos: clientes, fornecedores, distribuidores, concorrentes, governo e sociedade.

Clientes: principalmente médias-grandes (faturamento entre $\mathrm{R} \$ 90$ milhões e $\mathrm{R} \$ 300$ milhões) e grandes empresas privadas (faturamento acima de R 300 milhões) de todos 
os segmentos da economia e de qualquer região do país.

Fornecedores: irrelevantes para a realização das atividades-fim, que são desenvolvidas e executadas exclusivamente pelos funcionários da PwC Brasil e/ou por funcionários da PwC de outros países. Já no caso das atividades de apoio, há uma infinidade de fornecedores ligados à infraestrutura, tecnologia da informação, comunicação, gestão de recursos humanos, courier, aprovisionamentos de bens e serviços necessários relacionados às atividades-fim e correlatas.

Distribuidores: na definição tradicional da cadeia produtiva, compreendem as operações de transporte e entrega (logística) e não se aplicam à $\mathrm{PwC}$ Brasil, porque esta é uma prestadora de serviços, dentre os quais auditoria, consultoria tributária e societária, consultoria de negócios e international desks (transações comerciais entre Brasil e Ásia), diretamente aos clientes, por meio de equipes de especialistas. Diferentemente da Gestiona, no que tange ao conceito de canal de distribuição - interface entre empresa e cliente -, não existe a figura do finder, e a captação de novos clientes é atribuição dos próprios funcionários, geralmente a partir do cargo de gerente.

Concorrentes: as três demais integrantes do grupo Big Four (nomenclatura utilizada para as quatro maiores empresas contábeis especializadas em auditoria e consultoria do mundo: PricewaterhouseCoopers $(\mathrm{PwC})$, antes da aliança estratégica, Deloitte Touche Tohmatsu (DTT), KPMG e Ernst \& Young (EY)), outras grandes consultorias internacionais presentes no Brasil, consultorias nacionais de médio e grande porte, além de médios e grandes escritórios de direito tributário e empresarial.

Governo: possui papel secundário diante da natureza e do volume da maioria dos serviços oferecidos, tais como auditoria, assessoria em transações, consultoria de negócios, international desks. Já nas áreas de consultoria tributária e societária, o impacto do Governo é mais relevante, uma vez que envolve legislação tributária em todas as esferas (federal, estadual e municipal), que são definidas, regulamentadas e administradas por instituições governamentais.

Sociedade: a PwC Brasil inaugurou a área de Responsabilidade Corporativa no Brasil em 2000 para dar às ações sociais mais estrutura e direcionamento estratégico. Concentradas inicialmente na sede da firma, em São Paulo, essas iniciativas foram expandidas em 2005 a outros escritórios do país. Ao longo desse tempo, envolveu milhares de profissionais em projetos sociais ou voltados ao meio ambiente. A 
participação em programas de voluntariado ajuda os profissionais a fortalecer suas habilidades de liderança. Além disso, aumentou o nível de compromisso com as comunidades. Cria-se valor para a firma e a sociedade respeitando-se o meio ambiente e entendendo como as atividades realizadas afetam o mundo. Ações de redução do impacto ambiental se concentram em áreas como energia, controle e neutralização das emissões de gases do efeito estufa, consumo de papel e mobilidade (PWC, 2016).

\subsection{Objetivos e componentes do gerenciamento de riscos corporativos}

Como visto na Fundamentação Teórica, a norma COSO estabeleceu, para o Controle Interno das organizações, oito componentes do gerenciamento de riscos corporativos: ambiente interno; fixação de objetivos; identificação de eventos; avaliação de gerenciamento de riscos; resposta ao risco; atividade de controle; informação e comunicação; e monitoramento. Tais componentes formam um processo integrado e coordenado que se relaciona com os objetivos organizacionais, que, segundo o COSO, podem ser divididos em quatro categorias: estratégico, operacional, comunicação e conformidade, de tal sorte que a determinação do grau de eficácia do gerenciamento de riscos corporativos de uma organização corresponde ao julgamento decorrente da avaliação da presença e da eficácia do funcionamento dos oito elementos. Desse modo, os componentes também são critérios para o gerenciamento eficaz de riscos corporativos.

Por fim, o COSO afirma que o relacionamento direto entre os componentes e os objetivos organizacionais permeia tanto o nível organizacional quanto qualquer outro tipo de subunidade, tais como divisão, unidade de negócio e subsidiária (COSO, 2007, p. 7). No entanto, o presente estudo considera somente o nível organizacional, tendo em vista que a Gestiona não apresenta subunidade organizacional e a PwC Brasil, embora possua diversos escritórios pelo país que funcionam como extensões da matriz situada em São Paulo, estas não se configuram como subunidades organizacionais citadas pelo COSO. 


\subsubsection{Gestiona}

A partir da consolidação das três entrevistas realizadas e com base na definição supracitada de controle interno, o controle interno da Gestiona foi caracterizado de acordo com o objetivos organizacionais e componentes do gerenciamento de riscos corporativos propostos: ambiente interno; fixação de objetivos; identificação de eventos; avaliação de gerenciamento de riscos; resposta ao risco; atividade de controle; informação e comunicação; e monitoramento (COSO, 2007).

Ambiente interno. A estrutura organizacional da Gestiona possui poucos níveis hierárquicos e o fluxo de autoridade tende a ser centralizado e descendente a partir do sócio-fundador para questões mais relevantes, sendo praticamente horizontal entre os demais níveis hierárquicos e funcionais: (diretor comercial, consultores seniores, consultores plenos, consultores juniores e analistas, em paralelo, gerente financeiro, assistente administrativo e estagiários). Os consultores e analistas são agrupados em células por produto e setores empresariais. Efetivamente, a grande maioria das decisões é tomada em conjunto e consenso com os colaboradores envolvidos na questão. Há poucos controles e a burocracia interna é mínima. As políticas internas não estão sistematizadas, ou seja, não são explícitas, nem bem definidas e tampouco são periodicamente divulgadas. Na prática, as medidas são reativas e tomadas caso a caso, consultando-se funcionários mais antigos ou, em casos mais complexos, o sóciofundador.

Fixação de objetivos. Apresentados em quatro categorias. Estratégico: tornar-se uma consultoria boutique de referência nacional em gestão estratégica de recursos financeiros para inovação por meio de metodologias exclusivas e serviços de excelência personalizados e de alto valor agregado. Operacional: manter as despesas e custos fixos nos menores patamares possíveis, de modo a minimizar o principal risco na visão do sócio-fundador - o capital de giro. As vendas são feitas pelo próprio sócio-fundador, e, nesse sentido, investe-se tempo para formar parcerias comerciais com empresas que ofereçam serviços complementares ou diretamente relacionados, ou ainda com finders representantes comerciais que identificam e facilitam a entrada em clientes potenciais, dispostos a compartilhar os riscos (sem comissionamento prévio) e também os resultados (recebem um porcentual acima do padrão após o efetivo recebimento dos honorários). Comunicação: tornar-se a marca de referência em gestão estratégica de 
recursos financeiros para inovação para as empresas que atuam com PD\&I em território nacional por meio de atuação na internet, com o contínuo desenvolvimento de sites e portais de conhecimento, redes sociais e marketing digital, além da forte atuação em entidades de classe empresariais (associações, confederações, etc.), órgãos governamentais e instituições ligadas ao tema da PD\&I. Conformidade: desenvolver continuamente metodologias e processos internos com as melhores práticas para cada produto, de forma a garantir o cumprimento das legislações e regulamentos pertinentes aos incentivos fiscais e financiamentos subsidiados à inovação.

Identificação de eventos. Não existe um processo formal e periódico para identificação de oportunidades ou ameaças na Gestiona. Além disso, essa atribuição é praticamente exclusividade do sócio-fundador, que identifica as oportunidades por meio de sua rede de relacionamentos, exceção feita ao diretor comercial, que atua da mesma forma, ou seja, identifica novas oportunidades de negócio por meio de sua extensa rede de relacionamentos, participação em eventos e cursos. Já a identificação de novos riscos é feita majoritariamente de forma reativa, com base na experiência e conhecimento do sócio-fundador sobre o tema.

Avaliação de gerenciamento de riscos. Da mesma forma que a identificação de riscos, esta atribuição é praticamente restrita ao sócio-fundador e, eventualmente, ao diretor comercial. A avaliação é feita com base na experiência e conhecimento do sóciofundador, que, quando julga necessário, o que ocorre em raríssimos casos, consulta advogados ou especialistas no assunto antes de tomar a decisão.

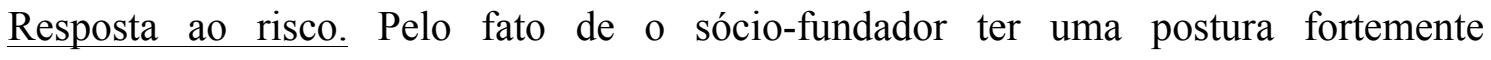
conservadora, a postura preponderante da Gestiona é evitar o risco a todo custo, o que pode ser evidenciado nos dois exemplos a seguir: 1. Comercial: a Gestiona não aceita cláusulas contratuais que comprometam montante superior aos honorários recebidos, prática comum de alguns concorrentes, e, nesses casos, sempre opta por declinar do contrato em questão; 2. Financeiro: a Gestiona não faz empréstimos bancários em hipótese alguma, nem para promover o aumento de vendas (alavancagem operacional), nem para o aumento de lucro líquido (alavancagem financeira), o que reduz o risco de insolvência, mas torna o potencial crescimento mais lento, em razão da baixa capacidade de investimento, sempre feito com recursos próprios.

Atividade de controle. As políticas e procedimentos para assegurar a execução das 
respostas aos riscos são sempre centralizados no sócio-fundador, que acaba tendo total domínio sobre a atividade de controle.

Informação e comunicação. Praticamente não existe comunicação e disseminação dos níveis e critérios de riscos internos aos colaboradores. Tais informações geralmente ficam restritas ao sócio-fundador e à gerente financeiro-administrativa, que acaba sendo a responsável pela execução das respostas aos riscos na grande maioria dos casos. Os demais colaboradores participam somente nos casos em que estão diretamente envolvidos.

Monitoramento. $\mathrm{O}$ acompanhamento ao longo da atividade é feito diretamente pelo sócio-fundador em todos os casos, até a conclusão dos mesmos.

\subsubsection{PwC Brasil}

Seguindo o procedimento adotado para a Gestiona, a partir da consolidação das três entrevistas realizadas e com base na definição supracitada de controle interno, o controle interno da PwC Brasil foi caracterizado de acordo com o objetivos organizacionais e componentes do gerenciamento de riscos corporativos propostos: ambiente interno; fixação de objetivos; identificação de eventos; avaliação de gerenciamento de riscos; resposta ao risco; atividade de controle; informação e comunicação; e monitoramento (COSO, 2007).

Ambiente interno. A PwC possui uma estrutura organizacional complexa, com dezenas de níveis hierárquicos (sócios, diretores, gerentes, analistas, etc.). Todos os níveis possuem subníveis (sênior, pleno, júnior, níveis I, II, III e IV, etc.). Além disso, atuação e responsabilidade podem ocorrer nos mercados local, regional, nacional e internacional. Os profissionais são alocados e geralmente estão restritos às suas respectivas áreas de atuação: auditoria, consultoria tributária e societária, consultoria de negócios, e podem ou não focar segmentos econômicos específicos, em áreas como sustentabilidade empresarial; gestão de riscos corporativos; reestruturações organizacionais, fusões, aquisições e recuperação de empresas; melhoria de processos e de desempenho, incluindo terceirização de funções contábeis e fiscais; entre outras. Há uma forte pressão exercida a partir da alta administração pelo atingimento de metas, geralmente bem agressivas, que permeiam todas as áreas da empresa, sejam atividadesfim ou atividades de apoio, e todos os níveis hierárquicos. Por fim, apresenta uma 
estrutura com elevado nível burocrático, caracterizada por regras, procedimentos e controles explícitos e periodicamente cobrados e validados.

Fixação de objetivos. Apresentados em quatro categorias. Estratégico: “fazer negócios com integridade. Preservar a nossa reputação e a do cliente. Respeitar as pessoas e o ambiente. Ser socialmente responsável. Trabalhar em conjunto e pensar sobre a maneira como trabalhamos. Considerar as dimensões éticas das nossas ações." (PWC, 2016). Operacional: "entregar o prometido e acrescentar valor para exceder as expectativas" (PWC, 2016), por meio da adoção das melhores práticas, treinamento contínuo e revisão dos trabalhos realizados pelos líderes do projeto e/ou superiores imediatos. Comunicação: divulgar e fortalecer a marca e os produtos $\mathrm{PwC}$ nacionalmente; para tanto, a PwC possui, entre outras áreas e canais, a Sala de Imprensa, responsável pela gestão das notícias veiculadas na imprensa, press releases (resumos de pesquisas e estudos) e artigos elaborados pelos especialistas da firma. Conformidade: garantir, além da qualidade e excelência dos trabalhos por meio da inovação, aprendizagem e agilidade (PWC, 2016), a criação e o aperfeiçoamento constante de processos padronizados e diretrizes para o total cumprimento das legislações e regulamentações pertinentes.

Identificação de eventos. A PwC possui áreas formais responsáveis pela identificação tanto em termos de oportunidades, como por exemplo o mapeamento e divulgação interna de novas legislações tributárias, que podem resultar em novos produtos a serem ofertados, quanto em termos de riscos, tais como garantir que os auditores cumpram as restrições de acesso ao mercado financeiro por exigência das regras e convenções nacionais e internacionais relacionadas aos trabalhos de auditoria. Além disso, a identificação de riscos é atribuição de todos os funcionários da empresa, que desde a contratação são expostos ao Código de Conduta e a treinamentos que orientam e fornecem diretrizes para que identifiquem potenciais riscos e ajam adequadamente. No que tange à identificação de oportunidades, é condição sine qua non para os colaboradores, especialmente a partir dos cargos gerenciais, que pretendam alcançar os níveis hierárquicos mais altos da organização.

Avaliação de gerenciamento de riscos. Os riscos identificados são apresentados ao superior imediato e assim sucessivamente até um diretor e/ou sócio encarregar-se de encaminhá-los à área de riscos, que em seguida abre procedimento para análise e classificação de acordo com a natureza do risco e critérios preestabelecidos. Com base 
nesse diagnóstico, as devidas providências são tomadas a fim de extinguir ou minimizar os possíveis impactos oriundos do risco em questão.

Resposta ao risco. A diretriz primordial da PwC é evitar ao máximo os riscos.

Atividade de controle. São diversas as políticas e procedimentos para evitar ao máximo os riscos, que se iniciam na assinatura do contrato de trabalho, momento em que cada colaborador passa a conhecer seus direitos e responsabilidades dentro da firma, o código de conduta, passa por diversos treinamentos que tratam do tema risco, além de ser periodicamente exposto e cobrado por procedimentos que asseguram a correta execução das respostas aos riscos. Para tanto, a $\mathrm{PwC}$ possui uma área interna dedicada à gestão de riscos corporativos.

Informação e comunicação. A área de riscos da $\mathrm{PwC}$ sistematicamente desenvolve materiais, atividades e cursos que são disponibilizados por diversos canais de comunicação (e-mail, intranet, apostilas, etc.) para todos os colaboradores da empresa.

Monitoramento. $\mathrm{O}$ acompanhamento é feito individualmente por meio de ferramentas de TI (Tecnologia da Informação) para as atividades on-line e mediante listas e testes para as atividades presenciais, ambas obrigatórias para todos os colaboradores da empresa, conforme cronograma anual predefinido.

\subsection{Contexto da Aliança Estratégica entre Gestiona e PwC}

O processo envolvendo o início das tratativas, a elaboração e os ajustes da aliança estratégica entre a Gestiona e a PwC até a assinatura do contrato durou aproximadamente 3 meses. $\mathrm{O}$ objetivo principal da aliança previa a atuação conjunta das empresas nos serviços relacionados aos incentivos fiscais à inovação com base nas seguintes premissas:

i. Natureza dos produtos envolvidos na Aliança: serviços de consultoria para utilização de incentivos físcais e financiamento público à inovação tecnológica, com destaque para Lei do Bem (incentivos à inovação tecnológica) e Lei da Informática (incentivos para o processo produtivo).

ii. Know-how comprovado da Gestiona na execução desse tipo de projeto;

iii. Presença no território nacional, networking e relacionamento com centenas de empresas, especialmente de grande porte, cliente-alvo principal para esse 
tipo de produto;

iv. Ambas poderiam continuar atuando de forma independente para esses mesmos serviços ou quaisquer outros, tanto para clientes antigos quanto para os novos, ou seja, não haveria exclusividade e/ou obrigatoriedade de atuarem juntas;

v. A decisão de atuarem juntas seria analisada para cada cliente potencial e aprovada por meio de consenso entre as partes caso a caso, o que inclui tanto a participação comercial de cada uma quanto à execução do projeto propriamente dito, que, por conseguinte, resultaria num porcentual proporcional de honorários em cada projeto;

vi. Nos casos aprovados, ficaria estabelecido que tanto o contrato quanto a interface relativa à responsabilidade perante o cliente seriam feitos exclusivamente pela PwC; para tanto, algumas pessoas-chave da Gestiona teriam status de funcionários formais da $\mathrm{PwC}$.

vii. Não haveria transferência de entre as partes, ou seja, as metodologias não poderiam ser utilizadas pela outra parte sem o consentimento da empresa proprietária, seja durante, seja após o término na parceria;

viii. Seria firmado um contrato "guarda-chuva" (contrato que possui objeto amplo), e para cada caso seria feita a abertura de uma espécie de Ordem de Serviço, detalhando as participações (comerciais e operacionais), direitos e responsabilidades de cada empresa, bem como a divisão dos honorários.

ix. Responsáveis pela negociação:

- PwC: sócio sênior da área de Tax (Impostos) e 2 gerentes seniores;

- Gestiona: sócio-fundador (autor do relato) e diretor comercial.

Com base nos principais riscos que compõem o ambiente de valor segundo Oliva (2015), será feita a contextualização dos fatores previamente considerados para a tomada de decisão de ambas as empresas em relação à formação da aliança estratégica.

\subsubsection{Gestiona}

Fatores considerados pela Gestiona para análise de viabilidade da aliança com a PwC:

- Estratégico: acessar o enorme mercado formado pelas empresas de grande porte 
atendidas pela $\mathrm{PwC}$, que se tornariam potenciais clientes para a Gestiona imediatamente após o início da operação. Possibilidade de desenvolver uma grande rede de contatos com diversos colaboradores da $\mathrm{PwC}$, bem como com seus clientes.

- Financeiro: aumentar as receitas oriundas dos contratos obtidos junto aos clientes da PwC.

- Operacional: absorver parte do know-how da $\mathrm{PwC}$ no que tange à prestação de serviços às grandes empresas, incluindo elaboração de propostas e contratos, além de procedimentos e metodologias de gestão, execução e apresentação dos trabalhos.

- Imagem: associar a marca da Gestiona à marca e a atributos, como solidez e excelência, mundialmente associados à PwC.

- Ético: incorporar as competências e os procedimentos da PwC para criar e implantar procedimentos que incentivem e demonstrem a ética, a integridade e a transparência para os funcionários da Gestiona.

- Inovação: desenvolver e/ou adaptar novos processos e controles internos para a Gestiona a partir de aprendizado e convivência com as melhores práticas utilizadas pela PwC.

- Sustentabilidade ambiental: fator não considerado pela Gestiona para a tomada de decisão em relação à aliança estratégica com a PwC.

- Know-how nos produtos: atuação há cerca de 10 anos no setor, centenas de clientes atendidos e desempenho superior à média dos concorrentes, por conta própria e em parceria com outras empresas prestadoras de serviços, em sua maioria bemsucedidas, especialmente com consultorias de pequeno porte e escritórios de advogados tributaristas.

\subsubsection{PwC Brasil}

Fatores considerados pela PwC para análise de viabilidade da aliança com a Gestiona:

- Estratégico: agregar ao portfólio da PwC novos produtos e ganhar parte do market share atual na área de incentivos fiscais à inovação tecnológica dos seus principais concorrentes, integrantes da Big Four, KPMG, Deloitte e Ernst \& Young, que ao longo dos últimos anos estruturam-se e ganharam participação nesse segmento. Além disso, ao oferecer esses produtos reduz a possibilidade de entrada de concorrentes em clientes da $\mathrm{PwC}$ que tenha tais demandas. 
- Financeiro: captar novos clientes e obter em clientes da carteira da PwC novas receitas oriundas dos serviços prestados em conjunto com a Gestiona.

- Operacional: absorver o know-how da Gestiona ao longo da execução dos trabalhos, uma vez que os mesmos serão gerenciados e revisados por funcionários da PwC.

- Imagem: agregar novos produtos

- Ético: alinhar questões de princípios, valores, transparência e ética.

- Inovação: fator não considerado para a tomada de decisão em relação à aliança estratégica com a Gestiona.

- Sustentabilidade ambiental: fator não considerado para a tomada de decisão em relação à aliança estratégica com a Gestiona.

- Know-how nos produtos: atuação esporádica; parte das experiências nesta área obteve resultados aquém do esperado e, em alguns casos, impactou negativamente no relacionamento com os clientes, prejudicando até mesmo outras frentes de negociação.

\subsection{Aliança estratégica de alto compartilhamento}

A caracterização da aliança estratégica tem por base o modelo conceitual de gestão de alianças estratégicas de alta reciprocidade proposto por Bruno e Vasconcellos (1997), objetiva analisar os motivos que levam os parceiros a uma aliança estratégica de alto compartilhamento, e fundamenta-se nos conceitos-chave: estabilidade e efetividade das alianças, que por sua vez são analisadas em quatro dimensões - institucional, organizacional, execução e criação de valor.

\section{Dimensão Institucional}

- Relação interpessoal. A relação interpessoal com os membros da PwC foi cordial e amigável a maior parte do tempo durante as negociações, especialmente com o sócio sênior, principal interlocutor da aliança estratégica, que desde o início das negociações demonstrou grande empolgação com as oportunidades advindas da parceria. 
- Conflitos e Histórico. Houve um princípio de desentendimento em razão do conflito de interesse com um diretor da $\mathrm{PwC}$ que já atuava com o principal produto - Lei do Bem: incentivos fiscais à inovação - havia cerca de dois anos em alguns clientes de grande porte e identificou na parceria com a Gestiona uma ameaça ao seu trabalho, tanto em termos de perda de atribuição quanto de uma possível identificação de falhas na execução dos trabalhos, haja vista a larga experiência da Gestiona no assunto. Após algumas reuniões e esclarecimentos adicionais, especialmente em relação à não obrigatoriedade de inclusão da Gestiona nos projetos relacionados à Lei do Bem em andamento na $\mathrm{PwC}$, a situação foi contornada e a relação entre esse diretor e os integrantes da Gestiona tornou-se amigável, tanto que 3 meses após o início oficial da aliança esse diretor convidou a Gestiona para atuar com ele em alguns de seus clientes.

- Excelência. Vale ressaltar que uma das grandes preocupações de ambas as partes desde o início foi e continua sendo a qualidade dos trabalhos a serem realizados. Nesse sentido, houve uma grande convergência, pois os padrões e modelos da PwC foram incorporados aos relatórios e demais entregáveis feitos pela Gestiona, cujos trabalhos realizados internamente, quando comparados aos trabalhos realizados pela $\mathrm{PwC}$, mostraram-se bem mais técnicos e detalhados, por envolverem expertise de engenheiros e/ou especialistas na área de inovação, não existentes na PwC.

- Interlocução. Os principais interlocutores de ambas as partes foram caracterizados desde o início, com foco nos níveis hierárquicos mais elevados de ambas as empresas, o que facilitou a comunicação em todas as etapas de negociação e, posteriormente, nas atividades comerciais e operacionais. Com o início e ao longo dos trabalhos, novos interlocutores foram incluídos de ambos os lados e o processo tornou-se mais descentralizado e informal, de modo a atender às necessidades dos clientes.

Dimensão Organizacional.

- Diferenças culturais. As diferenças culturais entre Gestiona e PwC são 
proporcionais ao porte e histórico das empresas; envolvem, fundamental mente, por parte da $\mathrm{PwC}$, hierarquia rígida, regras e processos bem definidos e lentos quando comparados aos da Gestiona. Na prática, a Gestiona e seus colaboradores foram obrigados a incorporar a cultura e os procedimentos da $\mathrm{PwC}$, o que causou certo desconforto inicialmente, mas algumas boas práticas foram adaptadas e incorporadas à Gestiona.

- Princípios e valores. Os princípios e valores foram convergentes desde o início e a honestidade e a ética pautaram e pautam até hoje o relacionamento entre as organizações.

- Transparência. Da mesma forma, sempre houve transparência de ambos os lados; prova disso é a continuidade da aliança que está prestes a completar 3 anos.

- Comunicação. A comunicação entre as empresas ocorre por diversos canais (presencial, e-mail e telefone) e diariamente, envolvendo gestores, consultores e analistas de ambos os lados na maioria das vezes; com menor frequência, semanalmente há contatos entre sócios e diretores para alinhamento dos trabalhos e próximos passos.

\section{Dimensão Execução.}

- Pauta de interação. Definida entre sócios e diretores de ambas as empresas com frequência média de três meses. Nessas reuniões, que sempre ocorrem nos escritórios da PwC, são definidos os clientes da PwC que serão abordados com base em critérios estratégicos predefinidos em conjunto e em oportunidades identificadas por qualquer uma das partes. Em seguida, localizam-se os focal points, gestores da PwC que possuem relacionamento com essas empresas, para que sejam feitos os contatos e marcação das reuniões comerciais, que sempre envolvem representantes de ambas as partes.

- Características contratuais. Quanto às questões contratuais envolvendo a Gestiona e 
a PwC, a Gestiona propôs que fosse celebrado um contrato "guarda-chuva" (contrato que possui objeto amplo), e, para cada caso, ou seja, em cada cliente, seria feita a abertura de uma espécie de Ordem de Serviço (documento padronizado, geralmente constituído de uma única página), que detalharia as especificidades do cliente, as participações (comerciais e operacionais), escopo, direitos e responsabilidades de cada parte (Gestiona e $\mathrm{PwC}$ ), bem como a divisão da remuneração respeitando-se critérios preestabelecidos com base no princípio da meritocracia.

Dimensão Criação de valor.

- Aplicação de conhecimento. Todos os serviços oferecidos pela aliança entre Gestiona e PwC podem ser divididos em duas macroatividades: "projetos" (mapeamento, análise, enquadramento e descrição, o que exige formação em engenharia ou em áreas correlatas, além de especialização em PD\&I) e "investimentos" (levantamento, análise, enquadramento e cálculo, geralmente feitos pelos próprios engenheiros ou por analistas, contabilistas e tributaristas). Sendo assim, duas situações são possíveis na execução dos trabalhos: 1. A equipe da Gestiona realiza ambas as macroatividades e a equipe da PwC faz a função de PMO (Project Management Office - monitoramento e gestão do cronograma); ou 2. A equipe da Gestiona realiza a macroatividade "projetos" e a equipe da $\mathrm{PwC}$ realiza, além da função PMO, a macroatividade "investimentos", pois se trata de uma atividade com forte correlação com diversos outros serviços prestados pela $\mathrm{PwC}$, mas que depois será revisada e validada pela Gestiona, responsável pela consolidação final do trabalho em todos os casos. Nota-se, especialmente no segundo caso, uma transferência de know-how da Gestiona para a PwC, com o intuito de orientar, justificar e demonstrar os conceitos e as análises de cada investimento em cada projeto.

- Impacto econômico. Em termos econômicos, houve e continua havendo ganho financeiro tanto para a Gestiona quanto para a PwC. Embora as remunerações sejam divididas e oscilem de $30 \%$ até $70 \%$, dependendo das atribuições da Gestiona (ou da 
PwC) em cada cliente, com base em critérios meritocráticos que consideram participação comercial e operacional, no caso da Gestiona a aliança compensa financeiramente pelo fato de o esforço comercial ser menor e o valor total dos honorários cobrados do cliente por hora, em média, ser mais elevado quando comparados aos índices obtidos diretamente pela Gestiona. Do lado da $\mathrm{PwC}$, o esforço comercial para ofertar e converter propostas em contratos é relativamente pequeno, dadas as características dos produtos oferecidos, que são remunerados no êxito, conforme ganho de caixa gerado; além disso, o fato de a PwC não necessitar de uma equipe de especialistas exclusiva para tais serviços permitiu que esses custos ficassem embutidos na remuneração exigida dos clientes.

Impacto Institucional. Em termos institucionais, também foram verificados ganhos para ambos os lados. No caso da Gestiona, associar a marca Gestiona à marca da PwC aumentou a credibilidade e facilitou o fechamento de contratos com grandes empresas. No caso da $\mathrm{PwC}$, houve pontos positivos e negativos. Na maioria dos casos, o relacionamento da PwC com os clientes foi fortalecido, diante dos excelentes resultados alcançados. Além disso, houve casos de empresas que até então não eram atendidas pela $\mathrm{PwC}$, e os produtos da Gestiona deram início ao relacionamento, que depois foi ampliando com a oferta e contratação de outros serviços oferecidos exclusivamente pela PwC. No entanto, em alguns poucos casos, como nos três exemplos a seguir, houve impacto negativo para a imagem da PwC: 1. O cliente não ficou satisfeito com o resultado do trabalho e, no caso, houve a cobrança prévia de honorários (fixos) por parte da $\mathrm{PwC}$ acima do ganho de caixa gerado para o cliente, o que causou o cancelamento do contrato, embora a PwC tenha mantido o relacionamento e a prestação de serviços em outras áreas; 2. Em outro cliente ativo da $\mathrm{PwC}$ para serviços que não envolviam a participação da Gestiona, havia um problema de relacionamento entre a focal point da empresa e o líder do projeto pela $\mathrm{PwC}$, que assumira também a gestão dos trabalhos iniciados pela Gestiona, o que acabou contaminando o relacionamento com a equipe da Gestiona e, apesar de o resultado técnico ter sido satisfatório, a pedido do cliente o contrato não foi renovado para o ano seguinte; 3. O cliente ficou satisfeito com o resultado e o trabalho já está no terceiro ciclo (ano); no entanto, alguns integrantes 
da empresa, dos níveis gerencial e operacional, já conheciam a Gestiona de outros locais e, dessa forma, compreenderam que o trabalho está sendo realizado pela Gestiona, embora oficialmente o contrato seja com a $\mathrm{PwC}$, que atua na empresa há anos e possui um excelente relacionamento com a diretoria, fortalecendo assim a a imagem da Gestiona ao invés da imagem da PwC.

- Impacto na aprendizagem. Em termos de aprendizagem, houve ganho para ambas as empresas. A Gestiona incorporou diversos aspectos culturais (políticas explícitas relacionadas aos riscos corporativos), procedimentos e controles internos, modelos de propostas, contratos, relatórios, entre outros, enquanto a $\mathrm{PwC}$ absorveu parte da metodologia da Gestiona para alguns produtos, em especial o carro-chefe, que é a Lei do Bem (incentivos fiscais à inovação); além disso, absorveu também modelos de propostas, contratos, relatórios e conteúdos técnicos.

- Feedback dos clientes. Cerca de $80 \%$ dos clientes mostraram-se muito satisfeitos, e a maior evidência disso é que os contratos foram mantidos ou renovados para os anos subsequentes, exceção feita aos clientes que por motivos diversos estavam inabilitados para utilizar os serviços oferecidos pela aliança Gestiona e PwC. Do restante, aproximadamente $12 \%$ demonstraram insatisfação com os serviços prestados e optaram pela não renovação dos contratos, e outros cerca de $8 \%$ não deixaram claros os motivos da descontinuidade dos trabalhos. 


\section{ANÁLISE DE DADOS}

Neste capítulo, desenvolvem-se a análise dos dados, além da aplicação de dois modelos teóricos, um referente ao nível de maturidade da Gestiona em gerenciamento de riscos corporativos e outro ao nível de estabilidade e eficácia da aliança estratégica entre Gestiona e PwC.

O capítulo está dividido em cinco seções, as três primeiras dedicadas à identificação, análise propriamente dita e avaliação dos riscos respectivamente. Além disso, a primeira etapa é puramente qualitativa; as outras duas possuem caráter quantitativo, com destaque para a determinação do grau de criticidade dos riscos e dimensões consolidadas.

As duas últimas seções referem-se às avaliações e determinações do nível de maturidade da Gestiona em gerenciamento de riscos corporativos e do nível de estabilidade e eficácia da aliança estratégica entre Gestiona e PwC.

\subsection{Identificação dos principais riscos corporativos para a Gestiona}

Como visto, a norma ISO 31000 (2009) afirma que o gerenciamento de riscos corporativos está intrinsecamente relacionado aos objetivos organizacionais. Por sua vez, o COSO (2007) ratifica essa afirmação e propõe a divisão dos objetivos organizacionais em quatro categorias: estratégico; operacional; comunicação; e conformidade. Dessa forma, partiremos dessa categorização e dos dados apresentados tanto em relação à Gestiona quanto à $\mathrm{PwC}$ e à aliança estratégica entre elas, para identificar os principais riscos corporativos para a Gestiona no que tange à aliança estratégica com a PwC.

Estratégico. A aliança com a PwC pode ser um entrave ao objetivo da Gestiona de tornar-se uma consultoria boutique de referência nacional, uma vez que o mercado pode interpretar essa parceria como uma simples relação entre cliente $(\mathrm{PwC})$ e fornecedor 
(Gestiona), o que demonstraria a incapacidade ou fragilidade da Gestiona na estrutura organizacional.

Operacional. A demanda de curto prazo oriunda dos clientes da PwC pode causar um aumento elevado e repentino das despesas e custos fixos, especialmente em relação aos recursos humanos, ou seja, contratação e treinamento de consultores. Isso impacta diretamente no fluxo de caixa, uma vez que o modelo de remuneração por taxa de sucesso implica prazos de recebimento que variam em média de 6 a 12 meses, tornando a empresa insolvente e ainda podendo gerar passivos trabalhistas (ações judiciais ligadas aos encargos sociais e trabalhistas). Além disso, a forte demanda potencial e a dedicação exigidas pela aliança com a PwC poderia enfraquecer os relacionamentos com os finders e ainda gerar conflito de interesses, já que ambos ( $\mathrm{PwC}$ e finder) poderiam atuar nas mesmas empresas-cliente.

Comunicação. $\mathrm{O}$ desejo da Gestiona em tornar-se a marca de referência na área de gestão estratégica de recursos financeiros poderia ser dificultado pela aliança com a PwC, pois os clientes em questão seriam atendidos única e exclusivamente sob a bandeira da $\mathrm{PwC}$ e, em caso de sucesso junto aos clientes, somente a marca da $\mathrm{PwC}$ seria valorizada. O mesmo se aplica aos workshops e eventos organizados pela $\mathrm{PwC}$, que, embora preparados e apresentados por integrantes da Gestiona, divulgariam somente a marca PwC.

Conformidade. O desenvolvimento interno e contínuo de metodologias e a disseminação do conhecimento entre os integrantes da Gestiona poderiam ser prejudicados em virtude da interpretação divergente da $\mathrm{PwC}$ sobre a legislação e regulamentação dos serviços, impactando na adequação dos produtos da Gestiona (metodologias, conteúdo técnico, apresentações, relatórios, planilhas automatizadas, etc.) aos modelos e exigências da PwC para serem utilizados por seus clientes.

Em continuidade à identificação dos principais riscos corporativos para a Gestiona envolvidos na aliança estratégica com a $\mathrm{PwC}$, utilizaremos o modelo conceitual para análise de riscos corporativos de Oliva (2015), no que tange ao ambiente de valor, formado pelos seguintes agentes: cliente, concorrente, fornecedor, distribuidor, governo e sociedade, além da empresa em si, que também é um agente que influencia e é influenciado pelos demais, cujos riscos são: financeiro, operacional, imagem, 
sustentabilidade ambiental, ética, inovação e estratégico (BALLOU, 2004; CHORA; SODJI, 2004; CHRISTOPHER; PECK, 2004; MANUJ; MENTZER, 2008; HILLSON, 1997; RIMS, 2006; OLIVA, 2015).

Pode-se notar que os riscos "estratégico" e "operacional" também fazem parte da categorização proposta pelo COSO e já foram analisados. Dessa forma, serão feitas análises dos demais riscos, a saber: financeiro, imagem, ética, inovação e sustentabilidade ambiental, propostos no modelo supracitado para identificar os principais riscos corporativos para a Gestiona envolvidos na aliança com a PwC.

Financeiro. O objetivo da Gestiona de aumentar as receitas por meio dos clientes oriundos da parceria com a PwC pode não ser alcançado por diversas razões: 1. A remuneração dos serviços contratados pode não atingir a margem operacional necessária para rentabilizar a Gestiona, pois o poder de barganha desses clientes da $\mathrm{PwC}$, geralmente grandes empresas, é muito forte, especialmente por existirem diversos concorrentes oferecendo os mesmos produtos; 2. Problema da bitributação, já que a PwC emite nota fiscal contra o cliente sobre o montante total dos honorários, e a Gestiona é obrigada emitir nota fiscal contra a $\mathrm{PwC}$ para receber sua parcela dos honorários; 3. O nível de exigência e procedimentos burocráticos existentes na $\mathrm{PwC}$ pode exigir um número extra considerável de homem-hora para a Gestiona, reduzindo seu retorno financeiro, inclusive a patamares abaixo do ponto de equilíbrio.

Imagem. Associar a imagem da Gestiona à imagem da $\mathrm{PwC}$ pode agregar valores como excelência e qualidade; contudo, tal associação pode colocar a Gestiona numa posição de mero fornecedor de mão de obra, causando um distanciamento da imagem de consultoria boutique almejada pela Gestiona.

Ética. Incorporar competências, procedimentos e posturas da $\mathrm{PwC}$ pode eventualmente descaracterizar as qualidades e valores presentes na cultura e no ambiente organizacional da Gestiona. Logo, é preciso analisar e mensurar os impactos positivos e negativos de tais práticas corporativas da PwC. 
Inovação. Da mesma forma que no caso anterior, absorver processos e controles internos que são considerados boas práticas no contexto da $\mathrm{PwC}$ pode não surtir os mesmos efeitos positivos na Gestiona.

Sustentabilidade ambiental. Não foram identificados riscos significativos em termos ambientais relacionados às atividades da Gestiona de forma independente, tampouco em relação à aliança estratégica com a PwC.

Ainda no intuito de identificar os outros riscos corporativos para a Gestiona no que tange à aliança estratégica com a PwC, observou-se que Das e Teng (1998), no estudo relacionado ao processo de formação de uma aliança estratégica, diferenciam os riscos em duas categorias: de relacionamento e de desempenho. O risco relacional refere-se à probabilidade de uma das partes não desenvolver um espírito de cooperação, ou seja, que acabe adotando um comportamento oportunista. Já o risco de desempenho, por sua vez, refere-se à probabilidade de que os objetivos estratégicos acertados entre os parceiros da aliança não sejam atingidos, mesmo havendo boa cooperação entre eles.

Risco relacional. No início das negociações entre Gestiona e PwC, houve uma resistência explícita por parte de um diretor da $\mathrm{PwC}$, que enxergou na aliança com a Gestiona uma ameaça à sua atuação em alguns clientes com o mesmo produto carrochefe da Gestiona - Lei do Bem: incentivos fiscais à inovação - e também à qualidade do trabalho realizado, já que este provavelmente seria revisado e questionado pelos consultores da Gestiona, e isso poderia ter se transformado num comportamento de resistência e até sabotagem à aliança com a Gestiona. Um risco oculto, ou seja, não previsto pela Gestiona, envolveu um fato lamentável: o falecimento do sócio sênior e patrocinador da aliança com a Gestiona, menos de um ano após o início da aliança, poderia despertar a cobiça de outros sócios e diretores, que de forma oportunista poderiam tentar incorporar os produtos da Gestiona, contratar alguns especialistas da Gestiona ou do mercado, cancelar a aliança e passar a atuar com os produtos em questão de forma independente. 
Risco de desempenho. Dois riscos identificados: 1. Desempenho aquém das expectativas da $\mathrm{PwC}$ e/ou dos clientes da PwC. Tal acontecimento, em última análise, poderia implicar o rompimento da aliança por parte da $\mathrm{PwC} ; 2$. Desempenho bem acima das expectativas, especialmente em termos financeiros. Isso poderia gerar duas posturas por parte da PwC: i) o montante da remuneração da Gestiona assumiria um patamar tão elevado que justificaria a criação de uma área e equipe internas, consultores contratados do mercado, para atuar por conta própria e, dessa forma, cancelar a aliança com a Gestiona; ii) propor a aquisição da Gestiona, ou seja, adquirir a carteira de clientes exclusivos da Gestiona, bem como incorporar sua equipe de consultores.

Vale mencionar também o trabalho realizado por Maloni e Benton (1997), que aponta alguns fatores a serem considerados numa aliança estratégica: diminuição da competitividade em caso de término da aliança, possível superestimação dos benefícios e possível influência do elo mais forte sobre o mais fraco, expectativa de redução dos custos de transação, redução de esforços administrativos e de transferências e melhor comunicação, que serão empregados a seguir para identificar riscos corporativos para a Gestiona envolvidos na aliança estratégica com a PwC.

Diminuição da competitividade em caso de término da aliança. A dedicação excessiva à aliança com a PwC em detrimento das outras frentes - em especial a atuação com os finders e demais parceiros comerciais, presença em fóruns e encontros sobre os temas dos produtos, bem como ações de marketing e divulgação da marca - pode reduzir a competitividade da Gestiona no médio e longo prazo.

Superestimação dos benefícios. Mercado potencial menor do que o estimado, especialmente em razão da forte presença de concorrentes e produtos cíclicos, ou seja, que precisam ser realizados periodicamente ad eternum e que tendem a fidelizar o cliente quando bem executados; e margem operacional menor do que a estimada por causa do forte poder de barganha do cliente, entre outros, podem gerar benefícios aquém das expectativas. 
Influência do elo mais forte sobre o mais fraco. A PwC pode impor condições desfavoráveis à Gestiona, determinar o ritmo de atuação comercial em virtude de outros interesses, ou ainda aceitar condições comerciais desfavoráveis para a aliança, mas benéficas para ela em outros aspectos, como, por exemplo, a possibilidade de oferecer pacotes de produtos exclusivos com margens mais interessantes e sem compensação para a Gestiona.

Aumento dos custos de transação, esforços administrativos e coordenação de processos. $\mathrm{Na}$ prática, os custos de transação podem aumentar em razão do maior número de procedimentos burocráticos e controles existentes na $\mathrm{PwC}$ e obrigatórios para a Gestiona durante a execução dos trabalhos. O mesmo vale para os esforços administrativos e a coordenação, uma vez que há maior lentidão para a análise e respostas às requisições, o que impacta negativamente nos cronogramas de trabalho e na quantidade média de homem-hora por atividade.

Piora na comunicação. A comunicação com o cliente tende a piorar e ser mais lenta, pois na maioria dos casos passa pela intermediação e avaliação dos integrantes da $\mathrm{PwC}$ antes de chegar ao cliente ou à Gestiona. Além disso, como deve ser feita pelos canais da $\mathrm{PwC}$, em caso de problemas técnicos, o solucionamento tende a ser mais burocrático e demorado.

O modelo de gestão de alianças estratégicas de alto compartilhamento (BRUNO; VANCONCELLOS, 1999) objetiva analisar os fatores relacionados à gestão de alianças estratégicas que envolvam alto grau de empenho e resultados por meio de dois conceitos-chave: estabilidade e efetividade das alianças, que por sua vez são analisadas em quarto dimensões: institucional, organizacional, execução e criação de valor. Vale ressaltar que o modelo é dinâmico, em razão da interação mutual das quatro dimensões e do fato de que estabilidade e efetividade são, por definição, suscetíveis a constantes mudanças de equilíbrio por causa da tensão entre cooperação e competição (BRUNO, 1995). 
Por conseguinte, lançaremos mão das quatro dimensões previstas no modelo de gestão de alianças estratégicas de alto compartilhamento de Bruno e Vasconcellos (1999): institucional, organizacional, execução e criação de valor, para finalizar a identificação dos principais riscos corporativos para a Gestiona envolvidos na aliança estratégica com a PwC.

Institucional. $\mathrm{O}$ respeito mútuo pode ser comprometido pelo conflito de interesses internos à $\mathrm{PwC}$, ou seja, outros sócios e/ou diretores que não concordassem com a aliança. A convergência de propósitos poderia ser abalada caso o desempenho ficasse abaixo das expectativas, a ponto de macular a imagem da $\mathrm{PwC}$ diante dos clientes atendidos pela aliança, ou abaixo da rentabilidade mínima, por exemplo; ou, ao contrário, caso um desempenho muito superior às expectativas justificasse a atuação da PwC por conta própria. A excelência como princípio, embora fosse premissa das duas empresas desde o início da aliança, pode gerar aumento considerável de homem-hora e reduzir ou inviabilizar a rentabilidade do produto; além disso, pela natureza dos produtos, que necessariamente dependem do aval muitas vezes subjetivo de técnicos de órgãos governamentais, não há garantia de obtenção do resultado desejado. Já a interlocução, se feita com funcionários da $\mathrm{PwC}$ que não estivessem cientes da aliança e/ou não tivessem conhecimento da natureza dos produtos da Gestiona, poderia causar atrasos ou falhas operacionais.

Organizacional. As diferenças culturais poderiam gerar problemas caso algum colaborador da Gestiona não estivesse preparado para se adequar ao grande número de regras e procedimentos burocráticos e restritivos existentes na $\mathrm{PwC}$ comparativamente aos da Gestiona. Diferenças em termos de princípios e valores, especialmente no que se refere à honestidade e transparência, entre as partes, mais especificamente entre os colaboradores diretamente envolvidos nos trabalhos, também poderiam gerar atritos e enfraquecer a aliança. A comunicação lenta ou pouco eficiente entre os integrantes da Gestiona e os da $\mathrm{PwC}$, especialmente nos times operacionais, pode gerar atrasos nos cronogramas, retrabalho, etc., reduzindo a qualidade do trabalho que provavelmente será percebida pelo cliente, além de tensão entre os integrantes de cada parte. 
Execução. Para ser efetiva, a pauta de interações precisa da aderência dos focal points, gestores (geralmente diretores e gerentes) da $\mathrm{PwC}$ que possuem relacionamento comercial com as empresas-alvo da aliança; no entanto, por diversos motivos, tais como outras prioridades ou pouca expectativa em relação ao retorno desses produtos, tal engajamento pode não ocorrer, comprometendo as metas da aliança. Escopo, obrigações e responsabilidades são definidos especificamente para cada cliente, via ordem de serviço; no entanto, ao longo dos trabalhos, em razão do elevado turnover (rotatividade interna ou externa) na $\mathrm{PwC}$ ou mesmo inexperiência do pessoal alocado, pode haver uma sobrecarga de trabalho para os integrantes da Gestiona e, eventualmente, tais custos não sejam compensados financeiramente. Isso pode causar rentabilidade negativa em um determinado cliente, gerando potenciais desgastes entre a Gestiona e a PwC. O modelo de ordem de serviço permite flexibilidade para adequação das condições operacionais e financeiras (honorários) em cada novo cliente da aliança, e geralmente é definido imediatamente antes do fechamento do negócio com cada cliente. No entanto, como exemplificado acima, pode haver alterações no escopo durante a execução dos trabalhos, com forte tendência de sobrecarregar a equipe da Gestiona. A alteração da ordem de serviço posteriormente pode gerar atrito entre as partes, e, caso não haja ajuste, isso pode gerar prejuízo para a Gestiona.

Criação de valor. $\mathrm{O}$ maior risco relacionado ao conhecimento envolvido nos produtos oferecidos pela aliança é a transferência (indesejada) do conhecimento da Gestiona para a PwC, que, apesar dos cuidados, ocorre ao longo da execução dos trabalhos à medida que os especialistas da Gestiona orientam, ensinam e demonstram metodologias, conceitos, etapas, procedimentos, etc. aos integrantes da $\mathrm{PwC}$, que participam da interface com o cliente e revisam o formato e outros itens pertinentes ao modus operandi da $\mathrm{PwC}$ antes das entregas oficiais ao cliente. Como visto, em alguns casos pode não haver ganho financeiro, como, por exemplo, quando há remuneração abaixo das expectativas em razão do poder de barganha do cliente ou de procedimentos internos equivocados que reduzam os resultados estimados, bitributação de honorários, excesso de homem-hora devido à busca pela excelência, procedimentos burocráticos exigidos pela $\mathrm{PwC}$ e/ou pelo cliente, aumento de escopo sem compensação financeira, etc. Em termos institucionais, pode haver impacto negativo pelo fato de a imagem da 
Gestiona ficar à sombra da $\mathrm{PwC}$ tanto nos clientes quanto nas palestras e eventos promovidos pela $\mathrm{PwC}$, mas apresentados por membros da Gestiona. Quanto à aprendizagem, incorporar em excesso procedimentos e controles da $\mathrm{PwC}$ pode aumentar desnecessariamente a burocracia interna, gerando custos operacionais e insatisfação nos colaboradores da Gestiona. Feedbacks positivos dos clientes fortalecem a aliança e valorizam a marca da PwC. Feedbacks negativos prejudicam a aliança e a marca da PwC. No longo prazo e no caso de a aliança ser cancelada, os feedbacks positivos e que provavelmente resultaram em fidelização dos clientes tornar-se-ão um problema para a Gestiona, que dificilmente terá a oportunidade para voltar a atendê-los. Já os feedbacks negativos, no longo prazo, serão prejudiciais tanto para a $\mathrm{PwC}$ quanto para a Gestiona, pois o cliente provavelmente lembrar-se-á dos participantes dos trabalhos malsucedidos.

\subsection{Análise dos riscos}

A análise dos riscos é uma parte essencial da gestão de riscos corporativos e deve permear os processos organizacionais no contexto do ambiente de valor no qual estão inseridos. Além disso, a análise de riscos em alianças estratégicas busca caracterizar os riscos que podem afetar o desempenho da aliança quanto à probabilidade de ocorrência e ao impacto na organização, ou seja, riscos internos e riscos externos à organização que envolvem as relações com o parceiro estratégico e os agentes no ambiente de negócios (COSO, 2004; ISO 31000 (2009), 2009; RIMS, 2006; EY, 2012; OLIVA, 2015).

Dessa forma, organizamos todos os riscos identificados considerando a origem da dimensão (natureza ou categoria, dependendo do autor ou da norma) do risco, a dimensão e o risco propriamente dito, o que resultou inicialmente em 34 riscos distribuídos em 15 dimensões, como pode ser verificado no Quadro 5.

Quadro 5 - Identificação dos riscos e respectivas dimensões de origem

\begin{tabular}{|c|l|c|l|}
\hline No. & Origem & Dimensão & \multicolumn{1}{c|}{ Risco } \\
\hline 1 & $\begin{array}{l}\text { COSO (2007); Oliva (2015) e } \\
\text { Maloni e Benton (1997) }\end{array}$ & Estratégico & $\begin{array}{l}\text { Visão distorcida do mercado em relação à } \\
\text { aliança }\end{array}$ \\
\hline
\end{tabular}




\begin{tabular}{|c|c|c|c|}
\hline 2 & $\begin{array}{l}\text { COSO (2007); Oliva (2015) e } \\
\text { Maloni e Benton (1997) }\end{array}$ & Operacional & $\begin{array}{l}\text { Necessidade de contratação de RH para } \\
\text { acompanhar a demanda }\end{array}$ \\
\hline 3 & $\begin{array}{l}\text { COSO (2007); Oliva (2015) e } \\
\text { Maloni e Benton (1997) }\end{array}$ & Operacional & Dedicação comercial excessiva à aliança \\
\hline 4 & COSO (2007) & Comunicação & $\begin{array}{l}\text { Excesso de procedimentos administrativos } \\
\text { burocráticos }\end{array}$ \\
\hline 5 & COSO (2007) & Conformidade & $\begin{array}{l}\text { Divergência na interpretação e } \\
\text { cumprimento das leis e regulamentos }\end{array}$ \\
\hline 6 & Oliva (2015) & Financeiro & $\begin{array}{l}\text { Forte poder de barganha dos grandes } \\
\text { clientes }\end{array}$ \\
\hline 7 & Oliva (2015) & Financeiro & $\begin{array}{l}\text { Não identificar uma solução legal para } \\
\text { evitar a bitributação }\end{array}$ \\
\hline 8 & Oliva (2015) & Financeiro & Excesso de exigências operacionais \\
\hline 9 & Oliva (2015) & Imagem & $\begin{array}{l}\text { Visão equivocada dos clientes sobre a } \\
\text { importância da Gestiona }\end{array}$ \\
\hline 10 & Oliva (2015) & Ética & $\begin{array}{l}\text { Falta de ética e de princípios por parte dos } \\
\text { integrantes do parceiro }\end{array}$ \\
\hline 11 & Oliva (2015) & Inovação & $\begin{array}{l}\text { Desenvolvimento de sistemas automáticos } \\
\text { com base na metodologia fornecida }\end{array}$ \\
\hline 12 & Oliva (2015) & $\begin{array}{l}\text { Sustentabilida- } \\
\text { de ambiental }\end{array}$ & $\begin{array}{l}\text { Demanda excessiva de impressão de } \\
\text { relatórios }\end{array}$ \\
\hline 13 & Das e Teng (1998) & Relacional & Oposição por parte de gestores \\
\hline 14 & Das e Teng (1998) & Relacional & Desligamento do sponsor da aliança \\
\hline 15 & Das e Teng (1998) & Desempenho & $\begin{array}{l}\text { Desempenho na prestação de serviços } \\
\text { abaixo das expectativas do cliente }\end{array}$ \\
\hline 16 & Das e Teng (1998) & Desempenho & $\begin{array}{l}\text { Desempenho financeiro da aliança muito } \\
\text { acima das expectativas }\end{array}$ \\
\hline 17 & $\begin{array}{l}\text { COSO (2007); Oliva (2015) e } \\
\text { Maloni e Benton (1997) }\end{array}$ & Estratégico & Término da aliança \\
\hline 18 & $\begin{array}{l}\text { COSO (2007); Oliva (2015) e } \\
\text { Maloni e Benton (1997) }\end{array}$ & Estratégico & $\begin{array}{l}\text { Mercado potencial e margens menores do } \\
\text { que a expectativa }\end{array}$ \\
\hline
\end{tabular}




\begin{tabular}{|c|c|c|c|}
\hline 19 & Maloni e Benton (1997) & Relacional & $\begin{array}{l}\text { Imposição do elo mais forte sobre o mais } \\
\text { fraco }\end{array}$ \\
\hline 20 & $\begin{array}{l}\text { COSO (2007); Oliva (2015) e } \\
\text { Maloni e Benton (1997) }\end{array}$ & Operacional & $\begin{array}{l}\text { Excesso de procedimentos administrativos } \\
\text { burocráticos, operacionais e de gestão }\end{array}$ \\
\hline 21 & $\begin{array}{l}\text { COSO (2007); Maloni e Benton } \\
\text { (1997) }\end{array}$ & Comunicação & $\begin{array}{l}\text { Imposição de canais de comunicação e da } \\
\text { forma de contato com os clientes }\end{array}$ \\
\hline 22 & Bruno e Vasconcellos (1999) & Institucional & Falta de respeito mútuo \\
\hline 23 & Bruno e Vasconcellos (1999) & Institucional & Divergência de propósitos \\
\hline 24 & Bruno e Vasconcellos (1999) & Institucional & Custos extras atrelados à excelência \\
\hline 25 & Bruno e Vasconcellos (1999) & Institucional & Interlocução inadequada \\
\hline 26 & $\begin{array}{l}\text { Oliva (2015); Bruno e } \\
\text { Vasconcellos (1999) }\end{array}$ & Organizacional & $\begin{array}{l}\text { Integrantes da Gestiona não se adequarem } \\
\text { às diferenças culturais }\end{array}$ \\
\hline 27 & $\begin{array}{l}\text { Oliva (2015); Bruno e } \\
\text { Vasconcellos (1999) }\end{array}$ & Organizacional & $\begin{array}{l}\text { Integrantes da Gestiona não se adequarem } \\
\text { aos princípios e valores } \mathrm{PwC}\end{array}$ \\
\hline 28 & $\begin{array}{l}\text { Oliva (2015); Bruno e } \\
\text { Vasconcellos (1999) }\end{array}$ & Organizacional & Falta de transparência \\
\hline 29 & Bruno e Vasconcellos (1999) & Execução & Prioridades comerciais divergentes \\
\hline 30 & Bruno e Vasconcellos (1999) & Execução & $\begin{array}{l}\text { Equipe da PwC despreparada para o } \\
\text { trabalho }\end{array}$ \\
\hline 31 & Bruno e Vasconcellos (1999) & Execução & $\begin{array}{l}\text { Aumento de escopo sem compensação } \\
\text { financeira }\end{array}$ \\
\hline 32 & Bruno e Vasconcellos (1999) & $\begin{array}{l}\text { Criação de } \\
\quad \text { valor }\end{array}$ & $\begin{array}{l}\text { Transferência indesejada de conhecimento } \\
\text { ao longo dos trabalhos }\end{array}$ \\
\hline 33 & Bruno e Vasconcellos (1999) & $\begin{array}{l}\text { Criação de } \\
\quad \text { valor }\end{array}$ & $\begin{array}{l}\text { Exigência de excelência por parte da PwC } \\
\text { ou dos clientes }\end{array}$ \\
\hline 34 & Bruno e Vasconcellos (1999) & $\begin{array}{l}\text { Criação de } \\
\quad \text { valor }\end{array}$ & Fidelização de cliente para a PwC \\
\hline
\end{tabular}

Fonte: o autor. 
Pela análise do Quadro 5, é possível notar a existência de riscos idênticos apontados em momentos e dimensões distintas ao longo do trabalho, por exemplo "custos extras atrelados à excelência", que aparece nas posições 24 e 33. Em outros casos, a proximidade da natureza dos riscos também é muito forte, como por exemplo "visão distorcida do mercado em relação à aliança", na posição 1, e "visão equivocada dos clientes sobre a importância da Gestiona”, na posição 9, o que também ocorre com “oposição por parte de gestores", posição 13, "divergência de propósitos”, posição 23, e “prioridades comerciais divergentes", posição 29. Dessa forma, faz-se necessário o compilamento desses riscos nas dimensões mais apropriadas, de forma a permitir uma melhor avaliação e o tratamento dos mesmos no contexto da aliança estratégica, conforme o Quadro 6. A numeração inicial foi mantida no intuito de facilitar a correlação entre os Quadros 5 e 6.

Quadro 6 - Consolidação dos riscos identificados

\begin{tabular}{|c|c|c|}
\hline No. & Riscos Correlatos & Riscos Consolidados \\
\hline 1 & $\begin{array}{l}\text { Visão distorcida do mercado em relação à } \\
\text { aliança }\end{array}$ & \multirow{2}{*}{$\begin{array}{l}\text { Visão distorcida do mercado em relação à } \\
\text { importância da Gestiona na aliança }\end{array}$} \\
\hline 9 & $\begin{array}{l}\text { Visão equivocada dos clientes sobre a } \\
\text { importância da Gestiona }\end{array}$ & \\
\hline 4 & $\begin{array}{l}\text { Excesso de procedimentos administrativos } \\
\text { burocráticos }\end{array}$ & \multirow{2}{*}{$\begin{array}{l}\text { Excesso de procedimentos administrativos } \\
\text { burocráticos }\end{array}$} \\
\hline 20 & $\begin{array}{l}\text { Excesso de procedimentos administrativos } \\
\text { burocráticos, operacionais e de gestão }\end{array}$ & \\
\hline 24 & Custos extras atrelados à excelência & \multirow{2}{*}{$\begin{array}{l}\text { Exigência de excelência por parte da PwC ou } \\
\text { dos clientes }\end{array}$} \\
\hline 33 & $\begin{array}{l}\text { Exigência de excelência por parte da } \mathrm{PwC} \text { ou } \\
\text { dos clientes }\end{array}$ & \\
\hline 10 & $\begin{array}{l}\text { Falta de ética e de princípios por parte dos } \\
\text { integrantes do parceiro }\end{array}$ & \multirow{2}{*}{$\begin{array}{l}\text { Falta de ética, princípios, respeito mútuo e/ou } \\
\text { transparência }\end{array}$} \\
\hline 22 & Falta de respeito mútuo & \\
\hline
\end{tabular}




\begin{tabular}{|c|c|c|}
\hline 28 & Falta de transparência & \\
\hline 13 & Oposição por parte de gestores & \multirow{3}{*}{$\begin{array}{l}\text { Oposição por conflitos de interesse, } \\
\text { divergências de propósitos ou prioridades } \\
\text { comerciais distintas }\end{array}$} \\
\hline 23 & Divergência de propósitos & \\
\hline 29 & Prioridades comerciais divergentes & \\
\hline 2 & $\begin{array}{l}\text { Necessidade de contratação de RH para } \\
\text { acompanhar a demanda }\end{array}$ & $\begin{array}{l}\text { Necessidade de contratação de RH para } \\
\text { acompanhar a demanda }\end{array}$ \\
\hline 3 & Dedicação comercial excessiva à aliança & Dedicação comercial excessiva à aliança \\
\hline 5 & $\begin{array}{l}\text { Dedicação técnica excessiva à aliança em razão } \\
\text { da demanda }\end{array}$ & $\begin{array}{l}\text { Dedicação técnica excessiva à aliança em } \\
\text { razão da demanda }\end{array}$ \\
\hline 6 & Forte poder de barganha dos grandes clientes & Forte poder de barganha dos grandes clientes \\
\hline 7 & $\begin{array}{l}\text { Não identificar uma solução legal para evitar a } \\
\text { bitributação }\end{array}$ & $\begin{array}{l}\text { Não identificar uma solução legal para evitar a } \\
\text { bitributação }\end{array}$ \\
\hline 8 & Excesso de exigências operacionais & Excesso de exigências operacionais \\
\hline 11 & $\begin{array}{l}\text { Desenvolvimento de sistemas automáticos com } \\
\text { base na metodologia fornecida }\end{array}$ & $\begin{array}{l}\text { Desenvolvimento de sistemas automáticos } \\
\text { com base na metodologia fornecida }\end{array}$ \\
\hline 12 & Demanda excessiva de impressão de relatórios & Demanda excessiva de impressão de relatórios \\
\hline 14 & Desligamento do sponsor da aliança & Desligamento do sponsor da aliança \\
\hline 15 & $\begin{array}{l}\text { Desempenho na prestação de serviços abaixo } \\
\text { das expectativas do cliente }\end{array}$ & $\begin{array}{l}\text { Desempenho na prestação de serviços abaixo } \\
\text { das expectativas do cliente }\end{array}$ \\
\hline 16 & $\begin{array}{l}\text { Desempenho financeiro da aliança muito acima } \\
\text { das expectativas }\end{array}$ & $\begin{array}{l}\text { Desempenho financeiro da aliança muito } \\
\text { acima das expectativas }\end{array}$ \\
\hline 17 & Término da aliança & Término da aliança \\
\hline 18 & $\begin{array}{l}\text { Mercado potencial e margens menores do que a } \\
\text { expectativa. }\end{array}$ & $\begin{array}{l}\text { Mercado potencial e margens menores do que } \\
\text { a expectativa. }\end{array}$ \\
\hline
\end{tabular}




\begin{tabular}{|c|c|c|}
\hline 19 & Imposição do elo mais forte sobre o mais fraco & $\begin{array}{l}\text { Imposição do elo mais forte sobre o mais } \\
\text { fraco }\end{array}$ \\
\hline 21 & $\begin{array}{l}\text { Imposição de canais de comunicação e da } \\
\text { forma de contato com os clientes }\end{array}$ & $\begin{array}{l}\text { Imposição de canais de comunicação e da } \\
\text { forma de contato com os clientes }\end{array}$ \\
\hline 25 & Interlocução inadequada & Interlocução inadequada \\
\hline 26 & $\begin{array}{l}\text { Integrantes da Gestiona não se adequarem às } \\
\text { diferenças culturais }\end{array}$ & $\begin{array}{l}\text { Integrantes da Gestiona não se adequarem às } \\
\text { diferenças culturais }\end{array}$ \\
\hline 27 & $\begin{array}{l}\text { Integrantes da Gestiona não se adequarem aos } \\
\text { princípios e valores da PwC }\end{array}$ & $\begin{array}{l}\text { Integrantes da Gestiona não se adequarem aos } \\
\text { princípios e valores da PwC }\end{array}$ \\
\hline 30 & Equipe da PwC despreparada para o trabalho & Equipe da PwC despreparada para o trabalho \\
\hline 31 & $\begin{array}{l}\text { Aumento de escopo sem compensação } \\
\text { financeira }\end{array}$ & $\begin{array}{l}\text { Aumento de escopo sem compensação } \\
\text { financeira }\end{array}$ \\
\hline 32 & $\begin{array}{l}\text { Transferência indesejada de conhecimento ao } \\
\text { longo dos trabalhos }\end{array}$ & $\begin{array}{l}\text { Transferência indesejada de conhecimento ao } \\
\text { longo dos trabalhos }\end{array}$ \\
\hline 34 & Fidelização de cliente para a PwC & Fidelização de cliente para a PwC \\
\hline
\end{tabular}

Fonte: o autor.

Outrossim, nota-se na terminologia utilizada pelos diversos autores e normas considerável proximidade entre algumas dimensões; nesse sentido, promovemos os seguintes agrupamentos também no intuito de facilitar a avaliação e o tratamento dos riscos na aliança estratégica em questão, conforme o Quadro 7.

Quadro 7 - Consolidação das dimensões correlatas

\begin{tabular}{|c|l|l|}
\hline No. & \multicolumn{1}{|c|}{ Dimensões correlatas } & \multicolumn{1}{|c|}{ Dimensão consolidada } \\
\hline 1 & Estratégico + Criação de Valor & Estratégico \\
\hline 2 & Operacional + Execução + Conformidade + Desempenho & Operacional \\
\hline 3 & Organizacional + Relacionamento + Comunicação + Ético & Organizacional \\
\hline 4 & Institucional + Imagem & Institucional \\
\hline
\end{tabular}




\begin{tabular}{|c|l|l|}
5 & Financeiro & Financeiro \\
\hline 6 & Inovação & Inovação \\
\hline 7 & Sustentabilidade ambiental & Sustentabilidade ambiental \\
\hline
\end{tabular}

Fonte: o autor.

O compilamento dos riscos e do agrupamento das dimensões resultou num total de 27 principais riscos, agrupados em 7 dimensões, conforme o Quadro 8 a seguir.

Quadro 8 - Dimensões consolidadas versus riscos consolidados

\begin{tabular}{|c|c|c|}
\hline No. & $\begin{array}{c}\text { Dimensão } \\
\text { consolidada }\end{array}$ & Risco Consolidado \\
\hline 1 & \multirow{5}{*}{ Estratégico } & Dedicação comercial excessiva à aliança \\
\hline 2 & & Término da aliança \\
\hline 3 & & Mercado potencial e margens menores do que a expectativa \\
\hline 4 & & Transferência indesejada de conhecimento ao longo dos trabalhos \\
\hline 5 & & Fidelização de cliente para a PwC \\
\hline 6 & \multirow{7}{*}{ Operacional } & Excesso de procedimentos administrativos burocráticos \\
\hline 7 & & Exigência de excelência por parte da $\mathrm{PwC}$ ou dos clientes \\
\hline 8 & & Necessidade de contratação de RH para acompanhar a demanda \\
\hline 9 & & Dedicação técnica excessiva à aliança em razão da demanda \\
\hline 10 & & Excesso de exigências operacionais \\
\hline 11 & & Desempenho na prestação de serviços abaixo das expectativas do cliente \\
\hline 12 & & Desempenho financeiro da aliança muito acima das expectativas \\
\hline
\end{tabular}




\begin{tabular}{|c|c|c|}
\hline 13 & & Equipe da $\mathrm{PwC}$ despreparada para o trabalho \\
\hline 14 & \multirow{9}{*}{ Organizacional } & Falta de ética, princípios, respeito mútuo e/ou transparência \\
\hline 15 & & $\begin{array}{l}\text { Oposição por conflitos de interesse, divergências de propósitos ou } \\
\text { prioridades comerciais distintas }\end{array}$ \\
\hline 16 & & Desligamento do sponsor da aliança \\
\hline 17 & & Imposição do elo mais forte sobre o mais fraco \\
\hline 18 & & $\begin{array}{l}\text { Imposição de canais de comunicação e da forma de contato com os } \\
\text { clientes }\end{array}$ \\
\hline 19 & & Interlocução inadequada \\
\hline 20 & & Integrantes da Gestiona não se adequarem às diferenças culturais \\
\hline 21 & & Integrantes da Gestiona não se adequarem aos princípios e valores da $\mathrm{PwC}$ \\
\hline 22 & & Aumento de escopo sem compensação financeira \\
\hline 23 & Institucional & $\begin{array}{l}\text { Visão distorcida do mercado em relação à importância da Gestiona na } \\
\text { aliança }\end{array}$ \\
\hline 24 & \multirow{2}{*}{ Financeiro } & Forte poder de barganha dos grandes clientes \\
\hline 25 & & Não identificar uma solução legal para evitar a bitributação \\
\hline 26 & Inovação & $\begin{array}{l}\text { Desenvolvimento de sistemas automáticos com base na metodologia } \\
\text { fornecida }\end{array}$ \\
\hline 27 & $\begin{array}{l}\text { Sustentabilidade } \\
\text { ambiental }\end{array}$ & Demanda excessiva de impressão de relatórios \\
\hline
\end{tabular}

Fonte: o autor.

\subsubsection{Grau de criticidade}

A análise de riscos destina-se a verificar o grau de criticidade (G.C.) dos riscos por meio de sua probabilidade de ocorrência (P.O.) e impacto na organização (I.O.). Aqui, usamse critérios prospectivos, pois os critérios projetivos não levam em conta o contexto 
atual em que a organização está inserida (COSO, 2007). Assim, considerando a fórmula G.C. = P.O. x I.O. e utilizando a seguinte escala de Likert para P.O.: 1, 2, 3, 4, 5, 6 e 7, onde 1 representa a menor probabilidade e 7 representa a maior probabilidade de ocorrência, e a seguinte escala Likert para o I.O.: 1 (impacto muito pequeno); 2 (impacto pequeno); 3 (impacto médio); 4 (impacto grande); 5 (impacto muito grande), determinou-se o grau de criticidade de cada um dos 27 riscos mapeados, observado na Tabela 2.

Tabela 2 - Grau de criticidade dos riscos consolidados

\begin{tabular}{|c|c|c|c|c|c|c|}
\hline No. & $\begin{array}{c}\text { Dimensão } \\
\text { consolidada }\end{array}$ & Risco Consolidado & P.O & Impacto na organização & I.O & G.C \\
\hline 1 & \multirow{5}{*}{ Estratégico } & $\begin{array}{l}\text { Dedicação comercial } \\
\text { excessiva à aliança }\end{array}$ & 3 & $\begin{array}{l}\text { Enfraquecimento com os } \\
\text { parceiros comerciais }\end{array}$ & 4 & 12 \\
\hline 2 & & Término da aliança & 6 & $\begin{array}{l}\text { Diminuição da competitividade } \\
\text { em razão da perda de outras } \\
\text { frentes e de imagem } \\
\text { institucional }\end{array}$ & 5 & 30 \\
\hline 3 & & $\begin{array}{l}\text { Mercado potencial e } \\
\text { margens menores do que a } \\
\text { expectativa }\end{array}$ & 5 & $\begin{array}{l}\text { Grande esforço comercial e } \\
\text { resultados financeiros aquém } \\
\text { das expectativas }\end{array}$ & 5 & 25 \\
\hline 4 & & $\begin{array}{l}\text { Transferência indesejada } \\
\text { de conhecimento ao longo } \\
\text { dos trabalhos }\end{array}$ & 6 & $\begin{array}{l}\text { Perda de parte do diferencial em } \\
\text { caso de cancelamento da aliança }\end{array}$ & 4 & 24 \\
\hline 5 & & $\begin{array}{l}\text { Fidelização de cliente para } \\
\text { a PwC }\end{array}$ & 5 & $\begin{array}{l}\text { Impossibilidade de atuar nestes } \\
\text { clientes após o término da } \\
\text { aliança }\end{array}$ & 4 & 20 \\
\hline 6 & \multirow{5}{*}{ Operacional } & $\begin{array}{l}\text { Excesso de procedimentos } \\
\text { administrativos } \\
\text { burocráticos }\end{array}$ & 2 & $\begin{array}{l}\text { Perda de comunicação e troca } \\
\text { de informações internas }\end{array}$ & 2 & 4 \\
\hline 7 & & $\begin{array}{l}\text { Exigência de excelência } \\
\text { por parte da PwC ou dos } \\
\text { clientes }\end{array}$ & 2 & $\begin{array}{l}\text { Aumento da quantidade de } \\
\text { homem-hora e redução das } \\
\text { margens operacionais }\end{array}$ & 3 & 6 \\
\hline 8 & & $\begin{array}{l}\text { Necessidade de } \\
\text { contratação de RH para } \\
\text { acompanhar a demanda }\end{array}$ & 6 & $\begin{array}{l}\text { Aumento de despesas/custos } \\
\text { fixos e problemas de fluxo de } \\
\text { caixa no curto prazo }\end{array}$ & 4 & 24 \\
\hline 9 & & $\begin{array}{l}\text { Dedicação técnica } \\
\text { excessiva à aliança em } \\
\text { razão da demanda }\end{array}$ & 4 & $\begin{array}{l}\text { Redução do desenvolvimento de } \\
\text { conteúdo próprio }\end{array}$ & 4 & 16 \\
\hline 10 & & $\begin{array}{l}\text { Excesso de exigências } \\
\text { operacionais }\end{array}$ & 5 & $\begin{array}{l}\text { Aumento de homem-hora e } \\
\text { consequentemente de despesas } \\
\text { operacionais }\end{array}$ & 4 & 20 \\
\hline
\end{tabular}




\begin{tabular}{|c|c|c|c|c|c|c|}
\hline 11 & & $\begin{array}{l}\text { Desempenho na prestação } \\
\text { de serviços abaixo das } \\
\text { expectativas do cliente }\end{array}$ & 3 & $\begin{array}{l}\text { Perda da estabilidade da aliança } \\
\text { Descontinuidade da aliança }\end{array}$ & 5 & 15 \\
\hline 12 & & $\begin{array}{l}\text { Desempenho financeiro da } \\
\text { aliança muito acima das } \\
\text { expectativas }\end{array}$ & 5 & $\begin{array}{l}\text { Descontinuidade da aliança em } \\
\text { favor de uma atuação } \\
\text { independente }\end{array}$ & 5 & 25 \\
\hline 13 & & $\begin{array}{l}\text { Equipe da PwC } \\
\text { despreparada para o } \\
\text { trabalho }\end{array}$ & 7 & $\begin{array}{l}\text { Aumento homem-hora } \\
\text { (treinamento, revisão e } \\
\text { retrabalho) e redução das } \\
\text { margens }\end{array}$ & 3 & 21 \\
\hline 14 & \multirow{9}{*}{$\begin{array}{l}\text { Organiza- } \\
\text { cional }\end{array}$} & $\begin{array}{l}\text { Falta de ética, princípios, } \\
\text { respeito mútuo e/ou } \\
\text { transparência }\end{array}$ & 2 & $\begin{array}{l}\text { Insatisfação por parte das } \\
\text { pessoas afeadas }\end{array}$ & 4 & 8 \\
\hline 15 & & $\begin{array}{l}\text { Oposição por conflitos de } \\
\text { interesse, divergências de } \\
\text { propósitos ou prioridades } \\
\text { comerciais distintas } \\
\end{array}$ & 7 & $\begin{array}{l}\text { Falta de cooperação na } \\
\text { execução dos trabalhos }\end{array}$ & 5 & 35 \\
\hline 16 & & $\begin{array}{l}\text { Desligamento do sponsor } \\
\text { da aliança }\end{array}$ & 7 & $\begin{array}{l}\text { Perda da estabilidade da aliança } \\
\text { Descontinuidade da aliança }\end{array}$ & 5 & 35 \\
\hline 17 & & $\begin{array}{l}\text { Imposição do elo mais } \\
\text { forte sobre o mais fraco }\end{array}$ & 6 & $\begin{array}{l}\text { Metas comercias e financeiras } \\
\text { não alcançadas }\end{array}$ & 5 & 30 \\
\hline 18 & & $\begin{array}{l}\text { Imposição de canais de } \\
\text { comunicação e da forma } \\
\text { de contato com os clientes }\end{array}$ & 6 & $\begin{array}{l}\text { Procedimentos mais lentos, } \\
\text { atrasos, falhas de comunicação e } \\
\text { retrabalho }\end{array}$ & 3 & 18 \\
\hline 19 & & Interlocução inadequada & 3 & $\begin{array}{l}\text { Lentidão nos processos e } \\
\text { incidência de retrabalho. }\end{array}$ & 3 & 9 \\
\hline 20 & & $\begin{array}{l}\text { Integrantes da Gestiona } \\
\text { não se adequarem às } \\
\text { diferenças culturais }\end{array}$ & 4 & $\begin{array}{l}\text { Desgaste na relação com a PwC } \\
\text { e consequente perda de } \\
\text { estabilidade da aliança }\end{array}$ & 4 & 16 \\
\hline 21 & & $\begin{array}{l}\text { Integrantes da Gestiona } \\
\text { não se adequarem aos } \\
\text { princípios e valores } \mathrm{PwC}\end{array}$ & 1 & $\begin{array}{l}\text { Desgaste na relação com a PwC } \\
\text { e consequente perda de } \\
\text { estabilidade da aliança }\end{array}$ & 5 & 5 \\
\hline 22 & & $\begin{array}{l}\text { Aumento de escopo sem } \\
\text { compensação financeira }\end{array}$ & 6 & $\begin{array}{l}\text { Aumento homem-hora e } \\
\text { redução das margens }\end{array}$ & 4 & 24 \\
\hline 23 & Institucional & \begin{tabular}{|l|} 
Visão distorcida do \\
mercado em relação à \\
importância da Gestiona \\
na aliança \\
\end{tabular} & 5 & $\begin{array}{l}\text { Perda de reputação e } \\
\text { credibilidade }\end{array}$ & 5 & 25 \\
\hline 24 & \multirow{2}{*}{ Financeiro } & $\begin{array}{l}\text { Forte poder de barganha } \\
\text { dos grandes clientes }\end{array}$ & 3 & Redução da receita bruta & 5 & 15 \\
\hline 25 & & $\begin{array}{l}\text { Não identificar uma } \\
\text { solução legal para evitar a } \\
\text { bitributação }\end{array}$ & 6 & Redução da receita líquida & 2 & 12 \\
\hline
\end{tabular}




\begin{tabular}{|c|c|l|c|l|c|c|}
26 & Inovação & $\begin{array}{l}\text { Desenvolvimento de } \\
\text { sistemas automáticos com } \\
\text { base na metodologia } \\
\text { fornecida }\end{array}$ & 5 & $\begin{array}{l}\text { Redução de participação no } \\
\text { escopo e na remuneração }\end{array}$ & 2 & 10 \\
\hline 27 & $\begin{array}{c}\text { Sustenta- } \\
\text { bilidade } \\
\text { ambiental }\end{array}$ & $\begin{array}{l}\text { Demanda excessiva de } \\
\text { impressão de relatórios }\end{array}$ & 3 & $\begin{array}{l}\text { Desperdício de papel e tinta, o } \\
\text { que onera a empresa e o meio } \\
\text { ambiente }\end{array}$ & 1 & 3 \\
\hline
\end{tabular}

Fonte: o autor.

A partir da Tabela 2, podem-se derivar diversas outras que, consequentemente, permitem diversas conclusões. Assim, a ordenação decrescente dos riscos com base nos graus de criticidade gera a Tabela 3 .

Tabela 3 - Ordenação decrescente dos riscos consolidados por grau de criticidade

\begin{tabular}{|c|c|c|c|c|c|c|}
\hline $\mathbf{N}$ & $\begin{array}{c}\text { Dimensão } \\
\text { consolidada }\end{array}$ & Risco Consolidado & P.O & Impacto na organização & I.O & G.C \\
\hline 1 & $\begin{array}{l}\text { Organiza- } \\
\text { cional }\end{array}$ & $\begin{array}{l}\text { Oposição por conflitos de } \\
\text { interesse, divergências de } \\
\text { propósitos ou prioridades } \\
\text { comerciais distintas }\end{array}$ & 7 & $\begin{array}{l}\text { Falta de cooperação na } \\
\text { execução dos trabalhos }\end{array}$ & 5 & 35 \\
\hline 2 & $\begin{array}{l}\text { Organiza- } \\
\text { cional }\end{array}$ & $\begin{array}{l}\text { Desligamento do sponsor da } \\
\text { aliança }\end{array}$ & 7 & $\begin{array}{l}\text { Perda da estabilidade da } \\
\text { aliança. Descontinuidade da } \\
\text { aliança }\end{array}$ & 5 & 35 \\
\hline 3 & $\begin{array}{l}\text { Organiza- } \\
\text { cional }\end{array}$ & $\begin{array}{l}\text { Imposição do elo mais forte } \\
\text { sobre o mais fraco }\end{array}$ & 6 & $\begin{array}{l}\text { Metas comerciais e financeiras } \\
\text { não alcançadas }\end{array}$ & 5 & 30 \\
\hline 4 & Estratégico & Término da aliança & 6 & $\begin{array}{l}\text { Diminuição da } \\
\text { competitividade em razão da } \\
\text { perda de outras frentes e de } \\
\text { imagem institucional }\end{array}$ & 5 & 30 \\
\hline 5 & Estratégico & $\begin{array}{l}\text { Mercado potencial e } \\
\text { margens menores do que a } \\
\text { expectativa }\end{array}$ & 5 & $\begin{array}{l}\text { Grande esforço comercial e } \\
\text { resultados financeiros aquém } \\
\text { das expectativas }\end{array}$ & 5 & 25 \\
\hline 6 & $\begin{array}{l}\text { Operacio- } \\
\text { nal }\end{array}$ & $\begin{array}{l}\text { Desempenho financeiro da } \\
\text { aliança muito acima das } \\
\text { expectativas. }\end{array}$ & 5 & $\begin{array}{l}\text { Descontinuidade da aliança } \\
\text { em favor de uma atuação } \\
\text { independente }\end{array}$ & 5 & 25 \\
\hline 7 & $\begin{array}{l}\text { Institucio- } \\
\text { nal }\end{array}$ & $\begin{array}{l}\text { Visão distorcida do mercado } \\
\text { em relação à importância da } \\
\text { Gestiona na aliança }\end{array}$ & 5 & $\begin{array}{l}\text { Perda de reputação e } \\
\text { credibilidade }\end{array}$ & 5 & 25 \\
\hline 8 & Estratégico & $\begin{array}{l}\text { Transferência indesejada de } \\
\text { conhecimento ao longo dos } \\
\text { trabalhos }\end{array}$ & 6 & $\begin{array}{l}\text { Perda de parte do diferencial } \\
\text { em caso de cancelamento da } \\
\text { aliança }\end{array}$ & 4 & 24 \\
\hline 9 & $\begin{array}{l}\text { Operacio- } \\
\text { nal }\end{array}$ & $\begin{array}{l}\text { Necessidade de contratação } \\
\text { de RH para acompanhar a } \\
\text { demanda }\end{array}$ & 6 & $\begin{array}{l}\text { Aumento de despesas/custos } \\
\text { fixos e problemas de fluxo de } \\
\text { caixa no curto prazo }\end{array}$ & 4 & 24 \\
\hline
\end{tabular}




\begin{tabular}{|c|c|c|c|c|c|c|}
\hline 10 & $\begin{array}{l}\text { Organiza- } \\
\text { cional }\end{array}$ & $\begin{array}{l}\text { Aumento de escopo sem } \\
\text { compensação financeira }\end{array}$ & 6 & $\begin{array}{l}\text { Aumento homem-hora e } \\
\text { redução das margens }\end{array}$ & 4 & 24 \\
\hline 11 & $\begin{array}{l}\text { Operacio- } \\
\text { nal }\end{array}$ & $\begin{array}{l}\text { Equipe da PwC } \\
\text { despreparada para o trabalho }\end{array}$ & 7 & $\begin{array}{l}\text { Aumento homem-hora } \\
\text { (treinamento, revisão e } \\
\text { retrabalho) e redução das } \\
\text { margens }\end{array}$ & 3 & 21 \\
\hline 12 & Estratégico & $\begin{array}{l}\text { Fidelização de cliente para a } \\
\text { PwC }\end{array}$ & 5 & $\begin{array}{l}\text { Impossibilidade de atuar } \\
\text { nestes clientes após o término } \\
\text { da aliança }\end{array}$ & 4 & 20 \\
\hline 13 & $\begin{array}{l}\text { Operacio- } \\
\text { nal }\end{array}$ & $\begin{array}{l}\text { Excesso de exigências } \\
\text { operacionais }\end{array}$ & 5 & $\begin{array}{l}\text { Aumento de homem-hora e } \\
\text { consequentemente de despesas } \\
\text { operacionais }\end{array}$ & 4 & 20 \\
\hline 14 & $\begin{array}{l}\text { Organiza- } \\
\text { cional }\end{array}$ & $\begin{array}{l}\text { Imposição de canais de } \\
\text { comunicação e da forma de } \\
\text { contato com os clientes }\end{array}$ & 6 & $\begin{array}{l}\text { Procedimentos mais lentos, } \\
\text { atrasos, falhas de comunicação } \\
\text { e retrabalho }\end{array}$ & 3 & 18 \\
\hline 15 & $\begin{array}{l}\text { Operacio- } \\
\text { nal }\end{array}$ & $\begin{array}{l}\text { Dedicação técnica excessiva } \\
\text { à aliança em razão da } \\
\text { demanda }\end{array}$ & 4 & $\begin{array}{l}\text { Redução do desenvolvimento } \\
\text { de conteúdo próprio }\end{array}$ & 4 & 16 \\
\hline 16 & $\begin{array}{l}\text { Organiza- } \\
\text { cional }\end{array}$ & $\begin{array}{l}\text { Integrantes da Gestiona não } \\
\text { se adequarem às diferenças } \\
\text { culturais }\end{array}$ & 4 & $\begin{array}{l}\text { Desgaste na relação com a } \\
\text { PwC e consequente perda de } \\
\text { estabilidade da aliança }\end{array}$ & 4 & 16 \\
\hline 17 & $\begin{array}{l}\text { Operacio- } \\
\text { nal }\end{array}$ & $\begin{array}{l}\text { Desempenho na prestação de } \\
\text { serviços abaixo das } \\
\text { expectativas do cliente }\end{array}$ & 3 & $\begin{array}{l}\text { Perda da estabilidade da } \\
\text { aliança. Descontinuidade da } \\
\text { aliança }\end{array}$ & 5 & 15 \\
\hline 18 & Financeiro & $\begin{array}{l}\text { Forte poder de barganha dos } \\
\text { grandes clientes }\end{array}$ & 3 & Redução da receita bruta & 5 & 15 \\
\hline 19 & Estratégico & $\begin{array}{l}\text { Dedicação comercial } \\
\text { excessiva à aliança }\end{array}$ & 3 & $\begin{array}{l}\text { Enfraquecimento com os } \\
\text { parceiros comerciais }\end{array}$ & 4 & 12 \\
\hline 20 & Financeiro & $\begin{array}{l}\text { Não identificar uma solução } \\
\text { legal para evitar a } \\
\text { bitributação }\end{array}$ & 6 & Redução da receita líquida & 2 & 12 \\
\hline 21 & Inovação & $\begin{array}{l}\text { Desenvolvimento de } \\
\text { sistemas automáticos com } \\
\text { base na metodologia } \\
\text { fornecida }\end{array}$ & 5 & $\begin{array}{l}\text { Redução de participação no } \\
\text { escopo e na remuneração }\end{array}$ & 2 & 10 \\
\hline 22 & $\begin{array}{l}\text { Organiza- } \\
\text { cional }\end{array}$ & Interlocução inadequada & 3 & $\begin{array}{l}\text { Lentidão nos processos e } \\
\text { incidência de retrabalho }\end{array}$ & 3 & 9 \\
\hline 23 & $\begin{array}{l}\text { Organiza- } \\
\text { cional }\end{array}$ & $\begin{array}{l}\text { Falta de ética, princípios, } \\
\text { respeito mútuo e/ou } \\
\text { transparência }\end{array}$ & 2 & $\begin{array}{l}\text { Insatisfação por parte das } \\
\text { pessoas afetadas }\end{array}$ & 4 & 8 \\
\hline
\end{tabular}




\begin{tabular}{|c|c|c|c|c|c|c|}
\hline 24 & $\begin{array}{l}\text { Operacio- } \\
\text { nal }\end{array}$ & $\begin{array}{l}\text { Exigência de excelência por } \\
\text { parte da PwC ou dos clientes }\end{array}$ & 2 & $\begin{array}{l}\text { Aumento da quantidade de } \\
\text { homem-hora e redução das } \\
\text { margens operacionais }\end{array}$ & 3 & 6 \\
\hline 25 & $\begin{array}{l}\text { Organiza- } \\
\text { cional }\end{array}$ & $\begin{array}{l}\text { Integrantes da Gestiona não } \\
\text { se adequarem aos princípios } \\
\text { e valores da PwC }\end{array}$ & 1 & $\begin{array}{l}\text { Desgaste na relação com a } \\
\text { PwC e consequente perda de } \\
\text { estabilidade da aliança. }\end{array}$ & 5 & 5 \\
\hline 26 & $\begin{array}{l}\text { Operacio- } \\
\text { nal }\end{array}$ & $\begin{array}{l}\text { Excesso de procedimentos } \\
\text { administrativos burocráticos }\end{array}$ & 2 & $\begin{array}{l}\text { Perda da comunicação e troca } \\
\text { de informações internas }\end{array}$ & 2 & 4 \\
\hline 27 & $\begin{array}{l}\text { Sustenta- } \\
\text { bilidade } \\
\text { ambiental }\end{array}$ & $\begin{array}{l}\text { Demanda excessiva de } \\
\text { impressão de relatórios }\end{array}$ & 3 & $\begin{array}{l}\text { Desperdício de papel e tinta, o } \\
\text { que onera a empresa e o meio } \\
\text { ambiente }\end{array}$ & 1 & 3 \\
\hline
\end{tabular}

Fonte: autor.

\subsection{Avaliação do nível de maturidade da Gestiona em GCM}

Assim sendo, com base na avaliação realizada no tópico anterior, apresentamos por meio da Tabela 4 os principais riscos organizacionais relacionados ao ambiente de valor, bem como os respectivos impactos na Gestiona e os graus de criticidade.

Tabela 4 - Principais riscos consolidados por dimensão consolidada

\begin{tabular}{|c|c|c|c|c|c|c|}
\hline No & $\begin{array}{c}\text { Dimensão } \\
\text { consoli- } \\
\text { dada }\end{array}$ & Risco Consolidado & P.O & Impacto na organização & I.O & G.C \\
\hline 1 & \multirow{2}{*}{$\begin{array}{l}\text { Organiza- } \\
\text { cional }\end{array}$} & $\begin{array}{l}\text { Oposição por conflitos de } \\
\text { interesse, divergências de } \\
\text { propósitos ou prioridades } \\
\text { comerciais distintas }\end{array}$ & 7 & $\begin{array}{l}\text { Falta de cooperação na } \\
\text { execução dos trabalhos }\end{array}$ & 5 & 35 \\
\hline 2 & & $\begin{array}{l}\text { Desligamento do sponsor } \\
\text { da aliança }\end{array}$ & 7 & $\begin{array}{l}\text { Perda da estabilidade da aliança. } \\
\text { Descontinuidade da aliança. }\end{array}$ & 5 & 35 \\
\hline 3 & \multirow{2}{*}{$\begin{array}{l}\text { Estraté- } \\
\text { gico }\end{array}$} & Término da aliança & 6 & $\begin{array}{l}\text { Diminuição da competitividade } \\
\text { em razão da perda de outras } \\
\text { frentes e de imagem } \\
\text { institucional }\end{array}$ & 5 & 30 \\
\hline 4 & & $\begin{array}{l}\text { Mercado potencial e } \\
\text { margens menores do que a } \\
\text { expectativa }\end{array}$ & 5 & $\begin{array}{l}\text { Grande esforço comercial e } \\
\text { resultados financeiros aquém } \\
\text { das expectativas }\end{array}$ & 5 & 25 \\
\hline 5 & \multirow{2}{*}{$\begin{array}{l}\text { Operacio- } \\
\text { nal }\end{array}$} & $\begin{array}{l}\text { Desempenho financeiro da } \\
\text { aliança muito acima das } \\
\text { expectativas }\end{array}$ & 5 & $\begin{array}{l}\text { Descontinuidade da aliança em } \\
\text { favor de uma atuação } \\
\text { independente }\end{array}$ & 5 & 25 \\
\hline 6 & & $\begin{array}{l}\text { Necessidade de } \\
\text { contratação de RH para } \\
\text { acompanhar a demanda }\end{array}$ & 6 & $\begin{array}{l}\text { Aumento de despesas/custos } \\
\text { fixos e problemas de fluxo de } \\
\text { caixa no curto prazo }\end{array}$ & 4 & 24 \\
\hline
\end{tabular}




\begin{tabular}{|c|c|c|c|c|c|c|}
\hline 7 & Imagem & $\begin{array}{l}\text { Visão distorcida do } \\
\text { mercado em relação à } \\
\text { importância da Gestiona } \\
\text { na aliança }\end{array}$ & 5 & $\begin{array}{l}\text { Perda de reputação e } \\
\text { credibilidade }\end{array}$ & 5 & 25 \\
\hline 8 & \multirow{2}{*}{ Financeiro } & $\begin{array}{l}\text { Forte poder de barganha } \\
\text { dos grandes clientes }\end{array}$ & 3 & Redução da receita bruta & 5 & 15 \\
\hline 9 & & $\begin{array}{l}\text { Não identificar uma } \\
\text { solução legal para evitar a } \\
\text { bitributação }\end{array}$ & 6 & Redução da receita líquida & 2 & 12 \\
\hline 10 & Inovação & $\begin{array}{l}\text { Desenvolvimento de } \\
\text { sistemas automáticos com } \\
\text { base na metodologia } \\
\text { fornecida }\end{array}$ & 5 & $\begin{array}{l}\text { Redução de participação no } \\
\text { escopo e na remuneração }\end{array}$ & 2 & 10 \\
\hline 11 & Ética & $\begin{array}{l}\text { Falta de ética, princípios, } \\
\text { respeito mútuo e/ou } \\
\text { transparência }\end{array}$ & 2 & $\begin{array}{l}\text { Insatisfação por parte das } \\
\text { pessoas afetadas. Desgaste no } \\
\text { relacionamento e na aliança }\end{array}$ & 4 & 8 \\
\hline 12 & $\begin{array}{l}\text { Sustenta- } \\
\text { bilidade } \\
\text { ambiental }\end{array}$ & $\begin{array}{l}\text { Demanda excessiva de } \\
\text { impressão de relatórios }\end{array}$ & 3 & $\begin{array}{l}\text { Desperdício de papel e tinta, o } \\
\text { que onera a empresa e o meio } \\
\text { ambiente }\end{array}$ & 1 & 3 \\
\hline
\end{tabular}

Fonte: o autor.

Isto posto, passamos ao terceiro e último nível proposto pelo modelo de Oliva (2015), que trata dos riscos relacionados ao ambiente de negócios, originados a partir dos seguintes eventos: econômicos, políticos, sociais, tecnológicos e ambientais, compilados na Tabela 5.

Tabela 5 - Riscos corporativos relacionados aos eventos do ambiente de negócios

\begin{tabular}{|c|c|c|c|c|c|c|}
\hline No & Evento & \multicolumn{1}{|c|}{ Risco } & P.o & Impacto na organização & I.O & G.C \\
\hline 1 & Político & $\begin{array}{l}\text { Alterações na legislação que } \\
\text { impliquem redução, restrição, } \\
\text { suspensão ou cancelamento } \\
\text { dos incentivos fiscais à } \\
\text { inovação }\end{array}$ & 6 & $\begin{array}{l}\text { Queda abrupta no faturamento, } \\
\text { que pode até mesmo causar } \\
\text { falência no médio prazo }\end{array}$ & 5 & $\mathbf{3 0}$ \\
\hline 2 & $\begin{array}{l}\text { Econô- } \\
\text { mico }\end{array}$ & $\begin{array}{l}\text { Crises sistêmicas (como a } \\
\text { atual) reduzem os } \\
\text { investimentos em PD\&I e } \\
\text { geram prejuízo fiscal }\end{array}$ & 7 & $\begin{array}{l}\text { Queda considerável de } \\
\text { faturamento, perda temporária } \\
\text { de clientes fidelizados (em } \\
\text { razão do prejuízo fiscal), } \\
\text { retração do mercado e } \\
\text { diminuição dos honorários }\end{array}$ & $\mathbf{2 8}$ \\
\hline
\end{tabular}




\begin{tabular}{|c|c|c|c|c|c|c|}
\hline 3 & $\begin{array}{l}\text { Tecnoló- } \\
\text { gico }\end{array}$ & $\begin{array}{l}\text { Órgãos e instituições } \\
\text { desenvolverem uma } \\
\text { plataforma que simplifique a } \\
\text { utilização dos incentivos } \\
\text { fiscais }\end{array}$ & 2 & $\begin{array}{l}\text { Drástica redução do portfólio e } \\
\text { do escopo oferecidos nos } \\
\text { produtos atuais, o que reduz o } \\
\text { valor agregado e } \\
\text { consequentemente a } \\
\text { remuneração e o faturamento }\end{array}$ & 5 & 10 \\
\hline 4 & Social & $\begin{array}{l}\text { Pressão da sociedade } \\
\text { (sindicatos, associações, } \\
\text { grupos políticos, etc.) para } \\
\text { extinção dos incentivos fiscais } \\
\text { à inovação. }\end{array}$ & 1 & $\begin{array}{l}\text { Queda abrupta no faturamento, } \\
\text { que pode até mesmo causar } \\
\text { falência no médio prazo. }\end{array}$ & 5 & 5 \\
\hline 5 & $\begin{array}{c}\text { Meio } \\
\text { ambiente }\end{array}$ & $\begin{array}{l}\text { Risco ergonômico causado por } \\
\text { LER (lesão por esforço } \\
\text { repetitivo) ou jornadas de } \\
\text { trabalho prolongadas que } \\
\text { causem problemas físicos na } \\
\text { equipe }\end{array}$ & 1 & $\begin{array}{l}\text { Autuação por parte de fiscais do } \\
\text { Ministério do Trabalho que } \\
\text { implique multa, indenizações, } \\
\text { etc. }\end{array}$ & 3 & 3 \\
\hline
\end{tabular}

Fonte: o autor.

Com os principais riscos corporativos mapeados nos três níveis propostos pelo modelo em questão, bem como os respectivos impactos na organização, passamos à análise dos 4 fatores explicativos para as práticas da gestão de riscos corporativos, quais sejam: (i) organizacional: representa o quanto a empresa se esforça para produzir uma gestão de riscos estruturada; (ii) tecnicidade: retrata a frequência com que a empresa faz uso de técnicas qualitativas ou quantitativas para apoiar o processo de gestão de riscos na corporação; (iii) transparência: revela quantas vezes a empresa aborda o assunto abertamente com seus colaboradores, buscando envolvê-los na gestão participativa dos riscos corporativos; e (iv) envolvimento: mostra o quanto a empresa é capaz de envolver outros agentes de seu ambiente de valor para tornar sua gestão de risco mais eficiente e eficaz (OLIVA, 2015).

A partir da caracterização da Gestiona, feita com base nos objetivos organizacionais e nos componentes de gerenciamento de riscos propostos pelo COSO (2007), a saber: ambiente interno; fixação de objetivos; identificação de eventos; avaliação de gerenciamento de riscos; resposta ao risco; atividade de controle; informação e comunicação; e monitoramento, bem como das forças e eventos que constituem o ambiente de negócios no contexto da aliança estratégica com a PwC, passamos à análise 
dos fatores explicativos da gestão de riscos corporativos.

Organizacional. Não existe um processo formal e periódico para identificação de riscos ou ameaças na Gestiona. Além disso, essa atribuição é praticamente exclusiva do sóciofundador, e a identificação de novos riscos é feita majoritariamente de forma reativa, com base na sua experiência e no conhecimento teórico sobre o tema. As políticas e procedimentos para assegurar a execução das respostas aos riscos são geralmente monitorados pelo gerente financeiro-administrativo e validadas pelo sócio-fundador, que acaba tendo total domínio da atividade de controle. Os principais controles implantados envolvem proteção e sigilo das informações tanto pertencentes à Gestiona quanto aos seus clientes e parceiros estratégicos, e envolvem todos os integrantes da empresa.

Tecnicidade. A Gestiona utiliza técnicas qualitativas e quantitativas para suportar seu processo de gestão de riscos, especialmente no que tange aos aspectos financeiros, tais como controles de fluxo de caixa, orçamento revisado, métricas e indicadores financeiros. Além disso, conta com procedimentos de proteção da propriedade intelectual e das informações próprias e dos clientes, por meio de contratos de responsabilidade, sistemas e procedimentos de backup e criptografia das informações, entre outros.

Transparência. Praticamente não existe comunicação e disseminação dos níveis e critérios de riscos internos aos colaboradores. Tais informações geralmente ficam restritas ao sócio-fundador e à gerente financeiro-administrativa, que acaba sendo a responsável pela execução das respostas aos riscos na grande maioria dos casos. Os demais colaboradores participam somente nos casos em que estão diretamente envolvidos.

Envolvimento. Suporte externo ocorre somente em poucos casos e de forma reativa, ou seja, quando um determinado evento gera um risco, e consiste majoritariamente na consulta a advogados ou especialistas no assunto em questão. 
Por fim, o modelo de maturidade na gestão de riscos corporativos em questão é composto de 5 categorias que resumem as características que devem estar presentes para que a organização seja considerada no respectivo nível de maturidade em gerenciamento de riscos. São eles:

Nível 1 - Gestão de Riscos Corporativos Insuficiente. Empresas que têm pouca consciência dos riscos corporativos. Não existe uma estrutura física ou conceitual dedicada aos riscos corporativos. A adoção de práticas de gestão de risco ocorre de forma não estruturada.

Nível 2 - Gestão de Riscos Corporativos Contingencial. Empresas que estão conscientes dos riscos a que estão sujeitas. Técnicas, ferramentas e métodos de gerenciamento de riscos são rudemente utilizadas. A gestão de risco é centralizada e é caracterizada pelo baixo envolvimento dos funcionários em geral.

Nível 3 - Gestão de Riscos Corporativos Estruturada. Empresas com um maior grau de organização dos processos relacionados à gestão de riscos corporativos. Há um uso mais intenso das técnicas, ferramentas e métodos de gerenciamento de riscos.

Nível 4 - Gestão de Riscos Corporativos Participativa. Empresas com alto nível de consciência e organização no que diz respeito aos processos relacionados à gestão de riscos corporativos. A gestão de riscos é mais descentralizada. A comunicação é uma parte integrante e importante no risco de gestão. O gerenciamento de riscos corporativos é guiado pela participação da maioria dos funcionários.

Nível 5 - Gestão de Riscos Corporativos Sistêmica. Empresas neste nível têm gestão de riscos corporativos consciente, organizada e transparente. Utilizam apoio externo de firmas de consultoria, parceiros e institutos de pesquisa, para melhorar a gestão de risco. Além disso, a empresa inclui cada vez mais a avaliação dos riscos do seu ambiente de valor na gestão de riscos, considerando que estes não respeitam as fronteiras organizacionais e são soberanos em relação aos limites da empresa. 
Apoiado nas peculiaridades organizacionais e no contexto do ambiente de valor da Gestiona, além de na aplicação dos fatores explicativos, podemos verificar que a Gestiona, embora não possua uma estrutura física, possui estrutura conceitual dedicada à gestão de riscos corporativos centrada na diretoria (sócio-fundador e gerente financeiro-administrativo); além disso, adota técnicas, ferramentas e métodos em sua gestão de riscos, pelo menos no que tange à proteção e sigilo das informações próprias e dos clientes. Ademais, a gestão de risco é centralizada e é caracterizada pelo baixo envolvimento dos funcionários em geral, o que coloca a Gestiona no Nível 2 - Gestão de Riscos Corporativos Contingencial, segundo os critérios do Modelo de Maturidade em Gerenciamento de Riscos Corporativos (OLIVA, 2015).

\subsection{Avaliação do nível de estabilidade e eficácia da aliança entre Gestiona e PwC}

O modelo conceitual de gestão de alianças estratégicas de alta reciprocidade proposto por Bruno e Vasconcellos (1997) tem como objetivo analisar os motivos que levam os parceiros de uma aliança, com alto grau de envolvimento no empenho e nos resultados, a obterem benefícios desproporcionais entre si ou impedem que os objetivos de um parceiro ou de ambos sejam alcançados.

O modelo fundamenta-se em dois conceitos-chave: estabilidade e efetividade das alianças, que por sua vez são analisadas em quatro dimensões: institucional, organizacional, execução e criação de valor. Vale ressaltar que o modelo é dinâmico, em razão da interação mutual das quatro dimensões e do fato de que estabilidade e efetividade são, por definição, suscetíveis a constantes mudanças de equilíbrio em razão da tensão entre cooperação e competição (BRUNO, 1995).

À vista disso, segue a aplicação do modelo de gestão de alianças estratégicas de alto compartilhamento à aliança estratégica entre Gestiona e $\mathrm{PwC}$, considerando-se os 2 primeiros anos de existência, a partir das quatro dimensões definidas: institucional, organizacional, execução e criação de valor, de modo a caracterizar o grau de estabilidade e eficácia da aliança. 


\section{Dimensão institucional}

- O respeito institucional mútuo e convergência dos objetivos. Muito forte no início das negociações, especialmente entre os sócios das duas empresas. No início da aliança, houve forte resistência por parte de um gerente sênior, que depois tornou-se diretor. No entanto, as divergências foram resolvidas e o respeito mútuo foi restabelecido até o falecimento do sponsor (sócio sênior) da aliança por parte da $\mathrm{PwC}$, pois alguns sócios tornaram-se indiferentes à parceria e outros foram claramente contrários à aliança, entendendo que a $\mathrm{PwC}$ poderia atuar de forma autônoma e maximizar os benefícios potenciais dos produtos em questão.

- Histórico de relacionamentos. Como previsto, formou-se uma rede de relacionamentos entre os funcionários de ambas as empresas, e os poucos desentendimentos apresentam níveis aceitáveis, considerando-se os relacionamentos internos de uma empresa. No entanto, essa rede limitou-se aos níveis hierárquicos operacionais, ou seja, até os gerentes responsáveis pela interface com os clientes. A Gestiona não conseguiu desenvolver uma rede robusta envolvendo diversos sócios e diretores da $\mathrm{PwC}$, o que dificultou o fortalecimento da cooperação entre as empresas.

- Excelência como princípio. Houve permanente busca pela excelência em todas as atividades técnicas e gerenciais de ambas as partes e a equipe da Gestiona adequouse aos padrões praticados pela $\mathrm{PwC}$.

- Identificação de interlocutores. Foi bem-sucedida nos perfis técnico e gerencial dos grupos envolvidos; no entanto, o mesmo não pode ser dito em relação aos interlocutores do alto escalão da $\mathrm{PwC}$, ou seja, sócios e diretores, o que ficou evidente, logo após o falecimento do sócio sênior e sponsor da aliança, com a postura de alguns sócios e diretores da PwC de romperem a aliança com a Gestiona.

\section{Dimensão organizacional}

- Tolerância às diferenças culturais. Houve um esforço muito maior por parte da Gestiona no sentido de assimilar e aprender a conviver com a cultura organizacional da PwC, especialmente em relação ao relativo excesso de procedimentos burocráticos, regras e padrões operacionais, além da relativa demora no tempo de resposta da maioria das atividades administrativas. Em razão fundamentalmente 
dessa capacidade de adaptação e tolerância por parte dos funcionários da Gestiona, não houve problemas relevantes nesse sentido.

- Capacidade de se envolver em diálogo. Presente desde o início da aliança, o diálogo entre as partes sempre foi cordial e respeitoso, especialmente nas atividades operacionais, com ambas se esforçando para absorver o modus operandi dos trabalhos e o conhecimento da outra, no intuito de obter um resultado de excelência junto a cada cliente.

- Comunicação. Como já demonstrado, a comunicação entre os integrantes foi e é importante nas atividades operacionais de ambos os lados. Já na comunicação com os clientes, em alguns poucos casos houve pequenas falhas e atrasos, mas em níveis aceitáveis, considerando-se a inexperiência de alguns envolvidos nessas atividades.

- Honestidade e ética. Em nenhum momento foi identificada alguma postura ou comportamento que denotasse desonestidade ou falta de ética ao longo de toda a aliança. Mesmo os casos de oposição à aliança Gestiona, demonstrada por um gerente sênior no início da aliança e por alguns sócios e diretores da $\mathrm{PwC}$ após o falecimento do sponsor, pode-se notar que configuram conflitos de interesse e objetivos divergentes, nada mais.

- Transparência. Somente após o falecimento do sponsor puderam-se notar algumas movimentações internas de sócios e diretores da $\mathrm{PwC}$ no intuito de paralisar os esforços comerciais em conjunto com a Gestiona, o que foi comunicado posteriormente, optando-se pela manutenção da aliança nos clientes ativos, bem como renovação desses contratos por tempo indeterminado, ou seja, respeitando-se a vontade dos clientes e o contrato "guarda-chuva" firmado entre Gestiona e PwC.

\section{Dimensão execução}

- Definição de pauta da interação. O plano de ação desenvolvido no início da aliança e atualizado a cada dois meses em média teve o engajamento dos envolvidos e foi implantado adequadamente até o falecimento do sponsor. Em seguida, alguns focal points, gestores (geralmente diretores e gerentes) da $\mathrm{PwC}$ responsáveis pelo contato com as empresas-alvo da aliança, tornaram-se menos comprometidos e o planejamento deixou de ser seguido.

- Definição do escopo e compromisso de executar projetos. Definidos para cada 
cliente, foram mantidos e respeitados por ambas as partes mesmo após o falecimento do sponsor. Alguns eventos pontuais, tais como turnover ou inexperiência dos integrantes da equipe da $\mathrm{PwC}$, ou ainda exigências extras de alguns clientes, geraram aumento de escopo e homem-hora para a Gestiona, mas o impacto disso foi pouco relevante no contexto da aliança.

- Adequação de competências compatíveis. Houve sinergia e complementariedade de competências na maioria das equipes formadas entre membros das duas empresas, o que gerou aprendizagem para ambas e, até mesmo, transferência indesejada, mas prevista, do conhecimento da Gestiona a alguns integrantes da PwC.

- Flexibilidade nos contratos. Uma das inovações em alianças estratégicas, o modelo de "contrato guarda-chuva" combinado com "ordem de serviço", permite flexibilidade para adequação das condições operacionais e financeiras (honorários) em cada novo cliente da aliança, que geralmente são definidas imediatamente antes do fechamento do negócio com cada cliente. Eventuais alterações de escopo por demanda dos clientes ou ainda inexperiência por parte de integrantes da $\mathrm{PwC}$, que gera sobrecarga para a equipe da Gestiona, tiveram pouco impacto diante do contexto da aliança.

\section{Dimensão de criação de valor}

- Domínio e aplicação do conhecimento. Ao longo da execução dos projetos houve aprendizagem para ambos os lados, com destaque para a absorção do conhecimento em relação aos produtos da Gestiona pela equipe da $\mathrm{PwC}$, e também do conhecimento da PwC em gestão de projetos por parte da equipe da Gestiona.

- Ganho econômico. Em termos econômicos, houve e continua havendo ganho tanto para a Gestiona quanto para a PwC. No caso da Gestiona, a vantagem refere-se ao fato de o esforço comercial ser menor e o valor total dos honorários cobrados do cliente por hora, em média, ser mais elevado se comparado aos cobrados dos clientes obtidos diretamente pela Gestiona. Do lado da PwC, o esforço comercial para ofertar e converter propostas em contratos é relativamente pequeno, dadas as características dos produtos oferecidos, que são remunerados no êxito, conforme o ganho de caixa gerado. No entanto, considerando-se o custo de oportunidade, a partir de um certo volume de receita tornar-se-ia mais vantajoso abdicar da aliança 
com a Gestiona, constituir uma equipe especializada própria, apesar do aumento dos custos fixos, e atuar de forma independente.

- Ganho organizacional e/ou institucional. No caso da Gestiona, associar a marca Gestiona à marca da $\mathrm{PwC}$ aumentou a credibilidade e facilitou a fechamento de contratos com grandes empresas. No caso da PwC, houve pontos positivos e negativos. $\mathrm{Na}$ maioria dos casos, o relacionamento da $\mathrm{PwC}$ com os clientes foi fortalecido, considerando-se os excelentes resultados alcançados; no entanto, em alguns casos o resultado não foi satisfatório e houve desgaste entre o cliente e a PwC. 


\section{RESULTADOS DA PESQUISA}

No intuito de atender aos objetivos desta dissertação, o presente capítulo foi organizado de modo a satisfazer a cada um dos cinco objetivos específicos propostos por meio da consolidação das análises feita no capítulo anterior.

\subsection{Riscos corporativos para a Gestiona envolvidos na Aliança}

O mapeamento dos riscos corporativos inicia-se pela análise dos objetivos organizacionais da Gestiona no contexto da aliança estratégica com a $\mathrm{PwC}$, pois, conforme a ISO 31.000, esses objetivos estão diretamente relacionados aos riscos corporativos. Por sua vez, o COSO ratifica essa afirmação e propõe a divisão dos objetivos organizacionais em quatro categorias: estratégico, operacional, comunicação e conformidade (COSO, 2007, p. 7). Tal análise resultou no primeiro conjunto de riscos corporativos para a Gestiona envolvidos na Aliança Estratégica com a PwC, conforme o Quadro 9.

Quadro 9 - Riscos identificados a partir das dimensões do COSO (2007)

\begin{tabular}{|c|c|c|l|}
\hline No. & Origem & Dimensão & \multicolumn{1}{c|}{ Risco } \\
\hline 1 & COSO (2007) & Estratégico & $\begin{array}{l}\text { Visão distorcida do mercado em } \\
\text { relação à aliança }\end{array}$ \\
\hline 2 & COSO (2007) & Operacional & $\begin{array}{l}\text { Necessidade de contratação de RH } \\
\text { para acompanhar a demanda }\end{array}$ \\
\hline 3 & COSO (2007) & Operacional & $\begin{array}{l}\text { Dedicação comercial excessiva à } \\
\text { aliança }\end{array}$ \\
\hline 4 & COSO (2007) & Comunicação & $\begin{array}{l}\text { Excesso de procedimentos } \\
\text { administrativos burocráticos }\end{array}$ \\
\hline 5 & COSO (2007) & Conformidade & $\begin{array}{l}\text { Divergência na interpretação e } \\
\text { cumprimento das leis e regulamentos }\end{array}$ \\
\hline
\end{tabular}

Fonte: o autor.

Em seguida, passamos para o modelo conceitual para análise de riscos corporativos 
(OLIVA, 2015), considerando cinco dos sete riscos existentes no ambiente de valor: financeiro, imagem, ética, inovação e sustentabilidade ambiental, pois os outros dois riscos, estratégico e operacional, também compõem a classificação proposta pelo COSO, analisada anteriormente. Assim, temos o segundo grupo de riscos corporativos para a Gestiona envolvidos na Aliança Estratégica com a PwC, conforme o Quadro 10.

Quadro 10 - Riscos identificados a partir das dimensões do ambiente de valor de Oliva (2015)

\begin{tabular}{|c|c|c|l|}
\hline No. & Origem & Dimensão & \multicolumn{1}{c|}{ Risco } \\
\hline 1 & Oliva (2015) & Financeiro & $\begin{array}{l}\text { Forte poder de barganha dos } \\
\text { grandes clientes }\end{array}$ \\
\hline 2 & Oliva (2015) & Financeiro & $\begin{array}{l}\text { Não identificar uma solução legal } \\
\text { para evitar a bitributação }\end{array}$ \\
\hline 3 & Oliva (2015) & Financeiro & Excesso de exigências operacionais \\
\hline 4 & Oliva (2015) & Imagem & $\begin{array}{l}\text { Visão equivocada dos clientes sobre } \\
\text { a importância da Gestiona }\end{array}$ \\
\hline 5 & Oliva (2015) & Ética & $\begin{array}{l}\text { Falta de ética e de princípios por } \\
\text { parte dos integrantes do parceiro }\end{array}$ \\
\hline 7 & Oliva (2015) & $\begin{array}{c}\text { Sustentabilidade } \\
\text { ambiental }\end{array}$ & $\begin{array}{l}\text { Demanda excessiva de impressão de } \\
\text { relatórios }\end{array}$ \\
\hline & Inovação & $\begin{array}{l}\text { Desenvolvimento de sistemas } \\
\text { automáticos com base na } \\
\text { metodologia fornecida }\end{array}$ \\
\hline
\end{tabular}

Fonte: o autor.

Na sequência, Das e Teng (1998), no estudo relacionado ao processo de formação de uma aliança estratégica, diferenciam os riscos em duas categorias: risco relacional, que se refere à probabilidade de uma das partes não desenvolver um espírito de cooperação, e o risco de desempenho, probabilidade de que os objetivos estratégicos acertados entre os parceiros da aliança não sejam atingidos, mesmo havendo boa cooperação entre eles. Daí chegamos ao terceiro conjunto de riscos corporativos para a Gestiona envolvidos na Aliança Estratégica com a PwC, conforme o Quadro 11. 
Quadro 11 - Riscos identificados a partir das dimensões de Das e Teng (1998)

\begin{tabular}{|c|c|c|l|}
\hline No. & Origem & Dimensão & \multicolumn{1}{|c|}{ Risco } \\
\hline 1 & $\begin{array}{c}\text { Das e Teng } \\
(1998)\end{array}$ & Relacional & Oposição por parte de gestores \\
\hline 2 & $\begin{array}{c}\text { Das e Teng } \\
(1998)\end{array}$ & Relacional & Desligamento do sponsor da aliança \\
\hline 4 & $\begin{array}{c}\text { Das e Teng } \\
(1998) \\
(1998)\end{array}$ & Desempenho & $\begin{array}{l}\text { Desempenho na prestação de } \\
\text { serviços abaixo das expectativas do } \\
\text { cliente }\end{array}$ \\
\hline
\end{tabular}

Fonte: o autor.

Sucessivamente, Maloni e Benton (1997) propõem os seguintes fatores a serem considerados numa aliança estratégica: diminuição da competitividade em caso de término da aliança, possível superestimação dos benefícios e possível influência do elo mais forte sobre o mais fraco, expectativa de redução dos custos de transação, redução de esforços administrativos e de transferências e melhor comunicação, que resultaram no quarto conjunto de riscos corporativos para a Gestiona envolvidos na Aliança Estratégica com a PwC, conforme o Quadro 13.

Quadro 13 - Riscos identificados a partir das dimensões de Maloni e Benton (1997)

\begin{tabular}{|c|c|c|l|}
\hline No. & Origem & Dimensão & \multicolumn{1}{|c|}{ Risco } \\
\hline 1 & $\begin{array}{c}\text { Maloni e } \\
\text { Benton (1997) }\end{array}$ & Estratégico & Término da aliança \\
\hline 3 & $\begin{array}{c}\text { Maloni e } \\
\text { Benton (1997) }\end{array}$ & Estratégico & $\begin{array}{l}\text { Mercado potencial e margens } \\
\text { menores do que a expectativa }\end{array}$ \\
\hline 4 & $\begin{array}{c}\text { Maloni e } \\
\text { Benton (1997) }\end{array}$ & Operacional & $\begin{array}{l}\text { Excesso de procedimentos } \\
\text { administrativos burocráticos, } \\
\text { operacionais e de gestão }\end{array}$ \\
\hline 5 & $\begin{array}{c}\text { Maloni e } \\
\text { Benton (1997) }\end{array}$ & Comunicaçação foro sobre o \\
\hline
\end{tabular}

Fonte: autor. 
Por fim, o modelo de gestão de alianças estratégicas de alto compartilhamento, de Bruno e Vanconcellos (1999), objetiva analisar os fatores relacionados à gestão de alianças estratégicas que envolvam alto grau de empenho e resultados por meio de dois conceitos-chave: estabilidade e efetividade das alianças, que por sua vez são analisadas em quatro dimensões: institucional, organizacional, execução e criação de valor, resultando no quinto e último conjunto de riscos corporativos para a Gestiona envolvidos na Aliança Estratégica com a PwC, conforme o Quadro 14.

Quadro 14 - Riscos identificados a partir das dimensões de Bruno e Vasconcellos (1999)

\begin{tabular}{|c|c|c|c|}
\hline No. & Origem & Dimensão & Risco \\
\hline 1 & $\begin{array}{c}\text { Bruno e } \\
\text { Vasconcellos } \\
(1999)\end{array}$ & Institucional & Falta de respeito mútuo \\
\hline 2 & $\begin{array}{c}\text { Bruno e } \\
\text { Vasconcellos } \\
\quad(1999)\end{array}$ & Institucional & Divergência de propósitos \\
\hline 3 & $\begin{array}{c}\text { Bruno e } \\
\text { Vasconcellos } \\
(1999)\end{array}$ & Institucional & $\begin{array}{l}\text { Custos extras atrelados à } \\
\text { excelência }\end{array}$ \\
\hline 4 & $\begin{array}{c}\text { Bruno e } \\
\text { Vasconcellos } \\
(1999)\end{array}$ & Institucional & Interlocução inadequada \\
\hline 5 & $\begin{array}{l}\text { Bruno e } \\
\text { Vasconcellos } \\
(1999)\end{array}$ & Organizacional & $\begin{array}{l}\text { Integrantes da Gestiona não se } \\
\text { adequarem às diferenças culturais }\end{array}$ \\
\hline 6 & $\begin{array}{l}\text { Bruno e } \\
\text { Vasconcellos } \\
(1999)\end{array}$ & Organizacional & $\begin{array}{l}\text { Integrantes da Gestiona não se } \\
\text { adequarem aos princípios e } \\
\text { valores da PwC }\end{array}$ \\
\hline 7 & $\begin{array}{c}\text { Bruno e } \\
\text { Vasconcellos } \\
\quad(1999)\end{array}$ & Organizacional & Falta de transparência \\
\hline 8 & $\begin{array}{c}\text { Bruno e } \\
\text { Vasconcellos } \\
(1999)\end{array}$ & Execução & $\begin{array}{l}\text { Prioridades comerciais } \\
\text { divergentes }\end{array}$ \\
\hline 9 & $\begin{array}{c}\text { Bruno e } \\
\text { Vasconcellos } \\
(1999)\end{array}$ & Execução & $\begin{array}{l}\text { Equipe da PwC despreparada para } \\
\text { o trabalho }\end{array}$ \\
\hline 10 & $\begin{array}{c}\text { Bruno e } \\
\text { Vasconcellos } \\
(1999)\end{array}$ & Execução & $\begin{array}{l}\text { Aumento de escopo sem } \\
\text { compensação financeira }\end{array}$ \\
\hline 11 & $\begin{array}{c}\text { Bruno e } \\
\text { Vasconcellos } \\
(1999)\end{array}$ & Criação de valor & $\begin{array}{l}\text { Transferência indesejada de } \\
\text { conhecimento ao longo dos } \\
\text { trabalhos }\end{array}$ \\
\hline
\end{tabular}




\begin{tabular}{|c|c|c|l|}
12 & $\begin{array}{c}\text { Bruno e } \\
\text { Vasconcellos } \\
(1999)\end{array}$ & Criação de valor & $\begin{array}{l}\text { Exigência de excelência por parte } \\
\text { da PwC ou dos clientes }\end{array}$ \\
\hline 13 & $\begin{array}{c}\text { Bruno e } \\
\text { Vasconcellos } \\
(1999)\end{array}$ & Criação de valor & Fidelização de cliente para a PwC \\
\hline
\end{tabular}

Fonte: o autor.

Após o mapeamento dos cinco conjuntos de riscos corporativos para a Gestiona envolvidos na Aliança Estratégica com a PwC, os riscos semelhantes foram compilados e relacionados com a dimensões consolidadas, isto é, agrupadas conforme a natureza de seus conceitos, e o resultado pode ser visto no Quadro 14 a seguir, composto dos 27 riscos agrupados em 7 dimensões.

Quadro 14 - Riscos e dimensões consolidadas

\begin{tabular}{|c|c|c|}
\hline No. & Dimensão consolidada & Risco Consolidado \\
\hline 1 & \multirow{5}{*}{ Estratégico } & Dedicação comercial excessiva à aliança \\
\hline 2 & & Término da aliança \\
\hline 3 & & Mercado potencial e margens menores do que a expectativa \\
\hline 4 & & Transferência indesejada de conhecimento ao longo dos trabalhos \\
\hline 5 & & Fidelização de cliente para a PwC \\
\hline 6 & \multirow{4}{*}{ Operacional } & Excesso de procedimentos administrativos burocráticos \\
\hline 7 & & Exigência de excelência por parte da $\mathrm{PwC}$ ou dos clientes \\
\hline 8 & & Necessidade de contratação de RH para acompanhar a demanda \\
\hline 9 & & Dedicação técnica excessiva à aliança em razão da demanda \\
\hline
\end{tabular}




\begin{tabular}{|c|c|c|}
\hline 10 & & Excesso de exigências operacionais \\
\hline 11 & & $\begin{array}{l}\text { Desempenho na prestação de serviços abaixo das expectativas do } \\
\text { cliente }\end{array}$ \\
\hline 12 & & Desempenho financeiro da aliança muito acima das expectativas \\
\hline 13 & & Equipe da PwC despreparada para o trabalho \\
\hline 14 & \multirow{9}{*}{ Organizacional } & Falta de ética, princípios, respeito mútuo e/ou transparência \\
\hline 15 & & $\begin{array}{l}\text { Oposição por conflitos de interesse, divergências de propósitos } \\
\text { ou prioridades comerciais distintas }\end{array}$ \\
\hline 16 & & Desligamento do sponsor da aliança \\
\hline 17 & & Imposição do elo mais forte sobre o mais fraco \\
\hline 18 & & $\begin{array}{l}\text { Imposição de canais de comunicação e da forma de contato com } \\
\text { os clientes }\end{array}$ \\
\hline 19 & & Interlocução inadequada \\
\hline 20 & & Integrantes da Gestiona não se adequarem às diferenças culturais \\
\hline 21 & & $\begin{array}{l}\text { Integrantes da Gestiona não se adequarem aos princípios e } \\
\text { valores da } \mathrm{PwC}\end{array}$ \\
\hline 22 & & Aumento de escopo sem compensação financeira \\
\hline 23 & Institucional & $\begin{array}{l}\text { Visão distorcida do mercado em relação à importância da } \\
\text { Gestiona na aliança }\end{array}$ \\
\hline 24 & \multirow{2}{*}{ Financeiro } & Forte poder de barganha dos grandes clientes \\
\hline 25 & & Não identificar uma solução legal para evitar a bitributação \\
\hline 26 & Inovação & $\begin{array}{l}\text { Desenvolvimento de sistemas automáticos com base na } \\
\text { metodologia fornecida }\end{array}$ \\
\hline 27 & Sustentabilidade ambiental & Demanda excessiva de impressão de relatórios \\
\hline
\end{tabular}

Fonte: o autor. 
Do Quadro 14 podemos depreender que a dimensão “organizacional” apresenta o maior número (nove) de riscos corporativos para a Gestiona no que tange à Aliança Estratégica com a PwC, seguida da dimensão "operacional”, com 8 riscos e, logo após, a dimensão "estratégico", com 5 riscos. Por outro lado, as dimensões "institucional", "inovação" e "sustentabilidade ambiental" apresentam somente um risco cada.

\subsection{Resultado da análise dos riscos para a Gestiona envolvidos na Aliança}

A análise de riscos destina-se a verificar o grau de criticidade dos riscos por meio de sua probabilidade de ocorrência e impacto na organização. Assim, a partir do Quadro 13, da definição dos impactos para a organização de cada risco, da determinação dos respectivos "pesos" e da aplicação da fórmula G.C. = P.O. x I.O., chegamos ao grau de criticidade dos 27 riscos identificados, conforme a Tabela 6, já colocada em ordem decrescente de grau de criticidade.

Tabela - Principais riscos e dimensões, impactos na organização e grau de criticidade

\begin{tabular}{|c|c|c|c|c|c|c|}
\hline No & $\begin{array}{c}\text { Dimensão } \\
\text { consolidada }\end{array}$ & Risco Consolidado & P.O & Impacto na organização & I.O & G.C \\
\hline 1 & $\begin{array}{l}\text { Organiza- } \\
\text { cional }\end{array}$ & $\begin{array}{l}\text { Oposição por conflitos de } \\
\text { interesse, divergências de } \\
\text { propósitos ou prioridades } \\
\text { comerciais distintas }\end{array}$ & 7 & $\begin{array}{l}\text { Falta de cooperação na } \\
\text { execução dos trabalhos }\end{array}$ & 5 & 35 \\
\hline 2 & $\begin{array}{l}\text { Organiza- } \\
\text { cional }\end{array}$ & $\begin{array}{l}\text { Desligamento do sponsor } \\
\text { da aliança }\end{array}$ & 7 & $\begin{array}{l}\text { Perda da estabilidade da } \\
\text { aliança. Descontinuidade da } \\
\text { aliança }\end{array}$ & 5 & 35 \\
\hline 3 & $\begin{array}{l}\text { Organiza- } \\
\text { cional }\end{array}$ & $\begin{array}{l}\text { Imposição do elo mais } \\
\text { forte sobre o mais fraco }\end{array}$ & 6 & $\begin{array}{l}\text { Metas comercias e financeiras } \\
\text { não alcançadas }\end{array}$ & 5 & 30 \\
\hline 4 & Estratégico & Término da aliança & 6 & $\begin{array}{l}\text { Diminuição da } \\
\text { competitividade em razão da } \\
\text { perda de outras frentes e } \\
\text { imagem institucional }\end{array}$ & 5 & 30 \\
\hline 5 & Estratégico & $\begin{array}{l}\text { Mercado potencial e } \\
\text { margens menores do que a } \\
\text { expectativa }\end{array}$ & 5 & $\begin{array}{l}\text { Grande esforço comercial e } \\
\text { resultados financeiros aquém } \\
\text { das expectativas }\end{array}$ & 5 & 25 \\
\hline 6 & Operacional & $\begin{array}{l}\text { Desempenho financeiro da } \\
\text { aliança muito acima das } \\
\text { expectativas }\end{array}$ & 5 & $\begin{array}{l}\text { Descontinuidade da aliança } \\
\text { em favor de uma atuação } \\
\text { independente }\end{array}$ & 5 & 25 \\
\hline
\end{tabular}




\begin{tabular}{|c|c|c|c|c|c|c|}
\hline 7 & Institucional & $\begin{array}{l}\text { Visão distorcida do } \\
\text { mercado em relação à } \\
\text { importância da Gestiona na } \\
\text { aliança }\end{array}$ & 5 & $\begin{array}{l}\text { Perda de reputação e } \\
\text { credibilidade }\end{array}$ & 5 & 25 \\
\hline 8 & Estratégico & $\begin{array}{l}\text { Transferência indesejada } \\
\text { de conhecimento ao longo } \\
\text { dos trabalhos }\end{array}$ & 6 & $\begin{array}{l}\text { Perda de parte do diferencial } \\
\text { em caso de cancelamento da } \\
\text { aliança }\end{array}$ & 4 & 24 \\
\hline 9 & Operacional & $\begin{array}{l}\text { Necessidade de } \\
\text { contratação de RH para } \\
\text { acompanhar a demanda }\end{array}$ & 6 & $\begin{array}{l}\text { Aumento de despesas/custos } \\
\text { fixos e problemas de fluxo de } \\
\text { caixa no curto prazo }\end{array}$ & 4 & 24 \\
\hline 10 & $\begin{array}{l}\text { Organiza- } \\
\text { cional }\end{array}$ & $\begin{array}{l}\text { Aumento de escopo sem } \\
\text { compensação financeira }\end{array}$ & 6 & $\begin{array}{l}\text { Aumento homem-hora e } \\
\text { redução das margens }\end{array}$ & 4 & 24 \\
\hline 11 & Operacional & $\begin{array}{l}\text { Equipe da PwC } \\
\text { despreparada para o } \\
\text { trabalho }\end{array}$ & 7 & $\begin{array}{l}\text { Aumento homem-hora } \\
\text { (treinamento, revisão e } \\
\text { retrabalho) e redução das } \\
\text { margens }\end{array}$ & 3 & 21 \\
\hline 12 & Estratégico & $\begin{array}{l}\text { Fidelização de cliente para } \\
\text { a PwC }\end{array}$ & 5 & $\begin{array}{l}\text { Impossibilidade de atuar } \\
\text { nestes clientes após o término } \\
\text { da aliança }\end{array}$ & 4 & 20 \\
\hline 13 & Operacional & $\begin{array}{l}\text { Excesso de exigências } \\
\text { operacionais }\end{array}$ & 5 & $\begin{array}{l}\text { Aumento de homem-hora e } \\
\text { consequentemente de despesas } \\
\text { operacionais }\end{array}$ & 4 & 20 \\
\hline 14 & $\begin{array}{l}\text { Organiza- } \\
\text { cional }\end{array}$ & $\begin{array}{l}\text { Imposição de canais de } \\
\text { comunicação e da forma } \\
\text { de contato com os clientes }\end{array}$ & 6 & $\begin{array}{l}\text { Procedimentos mais lentos, } \\
\text { atrasos, falhas de comunicação } \\
\text { e retrabalho }\end{array}$ & 3 & 18 \\
\hline 15 & Operacional & $\begin{array}{l}\text { Dedicação técnica } \\
\text { excessiva à aliança em } \\
\text { razão da demanda }\end{array}$ & 4 & $\begin{array}{l}\text { Redução do desenvolvimento } \\
\text { de conteúdo próprio }\end{array}$ & 4 & 16 \\
\hline 16 & $\begin{array}{l}\text { Organiza- } \\
\text { cional }\end{array}$ & $\begin{array}{l}\text { Integrantes da Gestiona } \\
\text { não se adequarem às } \\
\text { diferenças culturais }\end{array}$ & 4 & $\begin{array}{l}\text { Desgaste na relação com a } \\
\text { PwC e consequente perda de } \\
\text { estabilidade da aliança }\end{array}$ & 4 & 16 \\
\hline 17 & Operacional & $\begin{array}{l}\text { Desempenho na prestação } \\
\text { de serviços abaixo das } \\
\text { expectativas do cliente }\end{array}$ & 3 & $\begin{array}{l}\text { Perda da estabilidade da } \\
\text { aliança. Descontinuidade da } \\
\text { aliança }\end{array}$ & 5 & 15 \\
\hline 18 & Financeiro & $\begin{array}{l}\text { Forte poder de barganha } \\
\text { dos grandes clientes }\end{array}$ & 3 & Redução da receita bruta & 5 & 15 \\
\hline 19 & Estratégico & $\begin{array}{l}\text { Dedicação comercial } \\
\text { excessiva à aliança }\end{array}$ & 3 & $\begin{array}{l}\text { Enfraquecimento com os } \\
\text { parceiros comerciais }\end{array}$ & 4 & 12 \\
\hline 20 & Financeiro & $\begin{array}{l}\text { Não identificar uma } \\
\text { solução legal para evitar a } \\
\text { bitributação }\end{array}$ & 6 & Redução da receita líquida & 2 & 12 \\
\hline
\end{tabular}




\begin{tabular}{|c|c|c|c|c|c|c|}
\hline 21 & Inovação & $\begin{array}{l}\text { Desenvolvimento de } \\
\text { sistemas automáticos com } \\
\text { base na metodologia } \\
\text { fornecida }\end{array}$ & 5 & $\begin{array}{l}\text { Redução de participação no } \\
\text { escopo e na remuneração }\end{array}$ & 2 & 10 \\
\hline 22 & $\begin{array}{l}\text { Organiza- } \\
\text { cional }\end{array}$ & Interlocução inadequada & 3 & $\begin{array}{l}\text { Lentidão nos processos e } \\
\text { incidência de retrabalho }\end{array}$ & 3 & 9 \\
\hline 23 & $\begin{array}{l}\text { Organiza- } \\
\text { cional }\end{array}$ & $\begin{array}{l}\text { Falta de ética, princípios, } \\
\text { respeito mútuo e/ou } \\
\text { transparência }\end{array}$ & 2 & $\begin{array}{l}\text { Insatisfação por parte das } \\
\text { pessoas afeadas }\end{array}$ & 4 & 8 \\
\hline 24 & Operacional & $\begin{array}{l}\text { Exigência de excelência } \\
\text { por parte da PwC ou dos } \\
\text { clientes }\end{array}$ & 2 & $\begin{array}{l}\text { Aumento da quantidade de } \\
\text { homem-hora e redução das } \\
\text { margens operacionais }\end{array}$ & 3 & 6 \\
\hline 25 & $\begin{array}{l}\text { Organiza- } \\
\text { cional }\end{array}$ & $\begin{array}{l}\text { Integrantes da Gestiona } \\
\text { não se adequarem aos } \\
\text { princípios e valores da } \\
\text { PwC }\end{array}$ & 1 & $\begin{array}{l}\text { Desgaste na relação com a } \\
\text { PwC e consequente perda de } \\
\text { estabilidade da aliança }\end{array}$ & 5 & 5 \\
\hline 26 & Operacional & $\begin{array}{l}\text { Excesso de procedimentos } \\
\text { administrativos } \\
\text { burocráticos }\end{array}$ & 2 & $\begin{array}{l}\text { Perda da comunicação e troca } \\
\text { de informações internas }\end{array}$ & 2 & 4 \\
\hline 27 & $\begin{array}{l}\text { Sustenta- } \\
\text { bilidade } \\
\text { ambiental }\end{array}$ & $\begin{array}{l}\text { Demanda excessiva de } \\
\text { impressão de relatórios }\end{array}$ & 3 & $\begin{array}{l}\text { Desperdício de papel e tinta, } \\
\text { onerando a empresa e o meio } \\
\text { ambiente }\end{array}$ & 1 & 3 \\
\hline
\end{tabular}

Fonte: autor.

A partir da Tabela 6 acima podemos concluir, por exemplo, que os 3 principais riscos, a saber: oposição por conflitos de interesse, divergências de propósitos ou prioridades comerciais distintas; desligamento do sponsor da aliança; e imposição do elo mais forte sobre o mais fraco referem-se à dimensão consolidada "organizacional", mais especificamente ao relacionamento entre Gestiona e PwC.

Também podemos derivar diversas outras relações entre dimensões e riscos que, consequentemente, permitem outras conclusões, como se vê na Tabela 7, que apresenta até os 2 principais riscos de cada dimensão.

Tabela 7 - Principais riscos por dimensão consolidada

\begin{tabular}{|c|c|l|c|l|c|c|}
\hline No & $\begin{array}{c}\text { Dimensão } \\
\text { consoli- } \\
\text { dada }\end{array}$ & Risco Consolidado & P.O & Impacto na organização & I.O & G.C \\
\hline 1 & $\begin{array}{c}\text { Organiza- } \\
\text { cional }\end{array}$ & $\begin{array}{l}\text { Oposição por conflitos de } \\
\text { interesse, divergências de } \\
\text { propósitos ou prioridades } \\
\text { comerciais distintas }\end{array}$ & 7 & $\begin{array}{l}\text { Falta de cooperação na } \\
\text { execução dos trabalhos }\end{array}$ & $\mathbf{3 5}$ \\
\hline
\end{tabular}




\begin{tabular}{|c|c|c|c|c|c|c|}
\hline 2 & & $\begin{array}{l}\text { Desligamento do sponsor da } \\
\text { aliança }\end{array}$ & 7 & $\begin{array}{l}\text { Perda da estabilidade da } \\
\text { aliança. Descontinuidade da } \\
\text { aliança. }\end{array}$ & 5 & 35 \\
\hline 3 & \multirow{2}{*}{$\begin{array}{l}\text { Estraté- } \\
\text { gico }\end{array}$} & Término da aliança & 6 & $\begin{array}{l}\text { Diminuição da } \\
\text { competitividade devido à } \\
\text { perda de outras frentes e } \\
\text { imagem institucional }\end{array}$ & 5 & 30 \\
\hline 4 & & $\begin{array}{l}\text { Mercado potencial e margens } \\
\text { menores do que a expectativa }\end{array}$ & 5 & $\begin{array}{l}\text { Grande esforço comercial e } \\
\text { resultados financeiros aquém } \\
\text { das expectativas. }\end{array}$ & 5 & 25 \\
\hline 5 & \multirow{2}{*}{$\begin{array}{l}\text { Operacio- } \\
\text { nal }\end{array}$} & $\begin{array}{l}\text { Desempenho financeiro da } \\
\text { aliança muito acima das } \\
\text { expectativas }\end{array}$ & 5 & $\begin{array}{l}\text { Descontinuidade da aliança } \\
\text { em favor de uma atuação } \\
\text { independente }\end{array}$ & 5 & 25 \\
\hline 6 & & $\begin{array}{l}\text { Necessidade de contratação de } \\
\text { RH para acompanhar a } \\
\text { demanda }\end{array}$ & 6 & $\begin{array}{l}\text { Aumento de despesas/custos } \\
\text { fixos e problemas de fluxo de } \\
\text { caixa no curto prazo }\end{array}$ & 4 & 24 \\
\hline 7 & Imagem & $\begin{array}{l}\text { Visão distorcida do mercado } \\
\text { em relação à importância da } \\
\text { Gestiona na aliança }\end{array}$ & 5 & $\begin{array}{l}\text { Perda de reputação e } \\
\text { credibilidade }\end{array}$ & 5 & 25 \\
\hline 8 & \multirow{2}{*}{ Financeiro } & $\begin{array}{l}\text { Forte poder de barganha dos } \\
\text { grandes clientes }\end{array}$ & 3 & Redução da receita bruta & 5 & 15 \\
\hline 9 & & $\begin{array}{l}\text { Não identificar uma solução } \\
\text { legal para evitar a bitributação }\end{array}$ & 6 & Redução da receita líquida & 2 & 12 \\
\hline 10 & Inovação & $\begin{array}{l}\text { Desenvolvimento de sistemas } \\
\text { automáticos com base na } \\
\text { metodologia fornecida }\end{array}$ & 5 & $\begin{array}{l}\text { Redução de participação no } \\
\text { escopo e na remuneração }\end{array}$ & 2 & 10 \\
\hline 11 & Ética & $\begin{array}{l}\text { Falta de ética, princípios, } \\
\text { respeito mútuo e/ou } \\
\text { transparência }\end{array}$ & 2 & $\begin{array}{l}\text { Insatisfação por parte das } \\
\text { pessoas afetadas. Desgaste no } \\
\text { relacionamento e na aliança }\end{array}$ & 4 & 8 \\
\hline 12 & $\begin{array}{l}\text { Sustenta- } \\
\text { bilidade } \\
\text { ambiental }\end{array}$ & $\begin{array}{l}\text { Demanda excessiva de } \\
\text { impressão de relatórios }\end{array}$ & 3 & $\begin{array}{l}\text { Desperdício de papel e tinta, o } \\
\text { que onera a empresa e o meio } \\
\text { ambiente }\end{array}$ & 1 & 3 \\
\hline
\end{tabular}

Fonte: o autor.

Da Tabela 7 concluímos que os riscos atrelados às dimensões "inovação", "ética" e "sustentabilidade ambiental" possuem baixo grau de criticidade no que se refere aos riscos corporativos para a Gestiona envolvidos na aliança estratégica com a PwC. Já a Tabela 8 mostra que as dimensões consolidadas "organizacional", "operacional" e "estratégico" representam quase $87 \%$ do grau de criticidade ao qual a Gestiona está exposta em relação aos riscos corporativos relacionados à aliança com a PwC. 
Tabela 8 - Ordenação decrescente dos riscos consolidados por grau de criticidade

\begin{tabular}{|c|l|c|c|}
\hline No. & \multicolumn{1}{|c|}{ Dimensão consolidada } & $\begin{array}{c}\text { Grau de } \\
\text { criticidade }\end{array}$ & $\begin{array}{c}\text { Grau de } \\
\text { criticidade }\end{array}$ \\
\hline 1 & Organizacional & $\mathbf{1 8 0}$ & $\mathbf{3 7 , 0 \%}$ \\
\hline 2 & Operacional & $\mathbf{1 3 1}$ & $\mathbf{2 6 , 9 \%}$ \\
\hline 3 & Estratégico & $\mathbf{1 1 1}$ & $\mathbf{2 2 , 8 \%}$ \\
\hline 4 & Financeiro & $\mathbf{2 7}$ & $\mathbf{5 , 5 \%}$ \\
\hline 5 & Institucional & $\mathbf{2 5}$ & $\mathbf{5 , 1 \%}$ \\
\hline 6 & Inovação & $\mathbf{1 0}$ & $\mathbf{2 , 1 \%}$ \\
\hline 7 & Sustentabilidade ambiental & $\mathbf{3}$ & $\mathbf{0 , 6 \%}$ \\
\hline & Total & $\mathbf{4 8 7}$ & $\mathbf{1 0 0 \%}$ \\
\hline
\end{tabular}

Fonte: o autor.

Até aqui, considerando o modelo proposto por Oliva (2015), focamos a avaliação dos riscos corporativos nos níveis organizacional e ambiente de valor. No entanto, o modelo afirma que os riscos empresariais devem ser analisados de forma sistemática, considerando também o ambiente de negócios, composto dos seguintes eventos: econômico, político, social, tecnológico e ambiental. Como resultado, a Tabela 9 nos mostra que os riscos relacionados aos eventos "político" e "econômico" são os mais relevantes para a Gestiona no contexto da aliança com a PwC, representando $76 \%$ do grau de criticidade relativo aos riscos identificados no ambiente de negócios.

Tabela 9 - Riscos e grau de criticidade associados aos eventos do ambiente de negócios

\begin{tabular}{|c|c|l|c|c|c|c|}
\hline No & Evento & Risco & P.O. & Impacto na organização & I.O. & G.C. \\
\hline 1 & Político & $\begin{array}{l}\text { Alterações na legislação } \\
\text { que impliquem redução, } \\
\text { restrição, suspensão ou } \\
\text { cancelamento dos } \\
\text { incentivos fiscais à } \\
\text { inovação }\end{array}$ & 6 & $\begin{array}{l}\text { Queda abrupta no } \\
\text { faturamento, que pode até } \\
\text { mesmo causar falência no } \\
\text { médio prazo }\end{array}$ & 5 & $\mathbf{3 0}$ \\
\hline
\end{tabular}




\begin{tabular}{|c|c|c|c|c|c|c|}
\hline 2 & Econômico & $\begin{array}{l}\text { Crises sistêmicas (como a } \\
\text { atual) reduzem os } \\
\text { investimentos em PD\&I e } \\
\text { geram prejuízo fiscal }\end{array}$ & 7 & $\begin{array}{l}\text { Queda considerável de } \\
\text { faturamento, perda } \\
\text { temporária de clientes } \\
\text { fidelizados (em razão do } \\
\text { prejuízo fiscal), retração do } \\
\text { mercado e diminuição dos } \\
\text { honorários. }\end{array}$ & 4 & 28 \\
\hline 3 & Tecnológico & $\begin{array}{l}\text { Órgãos e instituições } \\
\text { desenvolverem uma } \\
\text { plataforma que simplifique } \\
\text { a utilização dos incentivos } \\
\text { fiscais }\end{array}$ & 2 & $\begin{array}{l}\text { Drástica redução do } \\
\text { portfólio e do escopo } \\
\text { oferecidos nos produtos } \\
\text { atuais, o que reduz o valor } \\
\text { agregado e, } \\
\text { consequentemente, a } \\
\text { remuneração e o } \\
\text { faturamento }\end{array}$ & 5 & 10 \\
\hline 4 & Social & $\begin{array}{l}\text { Pressão da sociedade } \\
\text { (sindicatos, associações, } \\
\text { grupos políticos, etc.) para } \\
\text { extinção dos incentivos } \\
\text { fiscais à inovação }\end{array}$ & 1 & $\begin{array}{l}\text { Queda abrupta no } \\
\text { faturamento, o que pode até } \\
\text { mesmo causar falência no } \\
\text { médio prazo }\end{array}$ & 5 & 5 \\
\hline 5 & $\begin{array}{c}\text { Meio } \\
\text { ambiente }\end{array}$ & $\begin{array}{l}\text { Risco ergonômico causado } \\
\text { por LER ou jornadas de } \\
\text { trabalho prolongadas que } \\
\text { causem problemas físicos } \\
\text { na equipe }\end{array}$ & 1 & $\begin{array}{l}\text { Autuação por parte de } \\
\text { fiscais do Ministério do } \\
\text { Trabalho que impliquem } \\
\text { multa, indenizações, etc. }\end{array}$ & 3 & 3 \\
\hline
\end{tabular}

Fonte: o autor.

\subsection{Nível de maturidade da Gestiona em gestão de riscos corporativos}

Como visto, o modelo de avaliação do nível de maturidade da Gestiona em gestão de riscos corporativos proposto por Oliva (2015) avalia os riscos corporativos em três níveis: organização, ambiente de valor e ambiente de negócios, pois a organização está exposta às forças e aos eventos resultantes desses três ambientes e a análise deve transcender suas fronteiras organizacionais. Isso posto e feito, o modelo sugere os 4 fatores explicativos para as práticas de gestão de riscos corporativos, quais sejam: (i) organizacional: esforço de produzir uma gestão de riscos estruturada; (ii) tecnicidade: frequência de uso de técnicas qualitativas ou quantitativas para apoiar o processo de gestão de riscos na corporação; (iii) transparência: regularidade com que a empresa aborda e envolve seus colaboradores na gestão participativa dos riscos corporativos; e (iv) envolvimento: capacidade da empresa de envolver outros agentes do seu ambiente de valor para tornar sua gestão de risco mais eficiente e eficaz. A análise dos fatores 
explicativos no contexto da gestão de riscos corporativos na Gestiona resultou no Quadro 15, a seguir.

Quadro 15 - Aplicação dos fatores explicativos à gestão de riscos da Gestiona

\begin{tabular}{|c|c|}
\hline $\begin{array}{c}\text { Fator } \\
\text { Explicativo }\end{array}$ & Gestiona \\
\hline \multirow{4}{*}{$\begin{array}{l}\text { Fator } 1 \\
\text { Organizacional }\end{array}$} & $\begin{array}{l}\text { Não existe processo estruturado e periódico para identificação de novos } \\
\text { riscos }\end{array}$ \\
\hline & Atribuição centrada na diretoria e alta gerência \\
\hline & Identificação de novos riscos feita de forma reativa \\
\hline & $\begin{array}{l}\text { Processos e controles existentes centrados nos aspectos financeiro, proteção } \\
\text { da informação e relacionamento governamental }\end{array}$ \\
\hline \multirow{2}{*}{$\begin{array}{l}\text { Fator } 2 \\
\text { Tecnicidade }\end{array}$} & Não existe aplicação de técnicas para identificação de novos riscos \\
\hline & $\begin{array}{l}\text { Há técnicas para gestão dos riscos já identificados, especialmente } \\
\text { financeiro e proteção da informação }\end{array}$ \\
\hline \multirow{2}{*}{$\begin{array}{c}\text { Fator } 3 \\
\text { Transparência }\end{array}$} & $\begin{array}{l}\text { Gestão participativa e comunicação efetiva no que tange aos riscos de } \\
\text { proteção da informação }\end{array}$ \\
\hline & Demais aspectos centrados na diretoria e alta gerência \\
\hline \multirow{2}{*}{$\begin{array}{c}\text { Fator } 4 \\
\text { Envolvimento }\end{array}$} & Suporte externo somente em casos pontuais, conforme demanda \\
\hline & $\begin{array}{l}\text { Análise do ambiente de valor feita periodicamente pela diretoria via } \\
\text { instituições governamentais e não governamentais }\end{array}$ \\
\hline
\end{tabular}

Fonte: o autor.

Por último, a aplicação propriamente dita do modelo de maturidade na gestão de riscos corporativos (GCM) com base nos 5 níveis de maturidade, nos 4 fatores explicativos, bem como nas peculiaridades organizacionais e no contexto do ambiente de valor da Gestiona, suscitou o Quadro 16. 
Quadro 16 - Análise do nível de maturidade da Gestiona em GCM

\begin{tabular}{|c|l|}
\hline Maturidade & \multicolumn{1}{c|}{ Gestiona - Características } \\
\hline \multirow{2}{*}{ Nível 2} & A diretoria tem consciência dos riscos corporativos \\
\cline { 2 - 3 } $\begin{array}{c}\text { GRC } \\
\text { Contingencial }\end{array}$ & $\begin{array}{l}\text { Possui estrutura conceitual dedicada à GRC centrada na diretoria } \\
\text { das informações internas e dos clientes }\end{array}$ \\
\cline { 2 - 3 } & $\begin{array}{l}\text { GRC centralizada na diretoria e com baixo envolvimento dos } \\
\text { funcionários }\end{array}$ \\
\hline
\end{tabular}

Fonte: o autor.

\subsection{Nível de estabilidade e eficiência da aliança estratégica entre Gestiona e PwC}

A aplicação do modelo de gestão de alianças estratégicas de alto compartilhamento para a aliança estratégica entre Gestiona e PwC, considerando-se seus 2 primeiros anos, resultou no Quadro 17, que apresenta as características da aliança a partir das 4 dimensões definidas no modelo - institucional, organizacional, execução e criação de valor -, e culmina com o nível de estabilidade e eficácia da aliança.

Quadro 17 - Nível de estabilidade e eficiência da aliança entre Gestiona e PwC

\begin{tabular}{|c|c|}
\hline Dimensão & Aliança Gestiona e PwC - Características \\
\hline \multirow{4}{*}{ Institucional } & $\begin{array}{l}\text { Respeito institucional e convergência de objetivos por parte da } \mathrm{PwC} \text { perderam } \\
\text { força após o falecimento do sócio sênior e sponsor da aliança. }\end{array}$ \\
\hline & $\begin{array}{l}\text { Histórico de relacionamentos positivo, especialmente nos níveis operacionais } \\
\text { Mostraram-se frágeis os relacionamentos ao nível de diretoria }\end{array}$ \\
\hline & Busca pela excelência desde o início da aliança e ao longo dos trabalhos \\
\hline & $\begin{array}{l}\text { A Identificação de interlocutores do alto escalão da PwC ao longo da aliança } \\
\text { foi malsucedida }\end{array}$ \\
\hline \multirow{2}{*}{ Organizacional } & $\begin{array}{l}\text { Diferenças culturais superadas especialmente pelo esforço da Gestiona em } \\
\text { assimilar e aprender a conviver com a cultura da organização PwC }\end{array}$ \\
\hline & $\begin{array}{l}\text { Capacidade de se envolverem em diálogo desde o início, especialmente em } \\
\text { atividades operacionais e administrativas }\end{array}$ \\
\hline
\end{tabular}




\begin{tabular}{|c|c|}
\hline & $\begin{array}{l}\text { Comunicação e compartilhamento foram efetivos desde do início, com poucas } \\
\text { falhas e de baixo impacto para a aliança }\end{array}$ \\
\hline & $\begin{array}{l}\text { Honestidade e ética sempre estiveram presentes de ambos os lados, mesmo nos } \\
\text { momentos de conflito }\end{array}$ \\
\hline & $\begin{array}{l}\text { Transparência predominou até o falecimento do sócio da PwC e sponsor da } \\
\text { aliança. Menos efetiva por parte da alta gestão da PwC após o ocorrido }\end{array}$ \\
\hline \multirow{5}{*}{ Execução } & Plano de ação desenvolvido e implantado parcialmente \\
\hline & Menor comprometimento por parte da PwC após falecimento do sponsor \\
\hline & $\begin{array}{l}\text { Definição do escopo e execução dos projetos em cada cliente foram respeitados } \\
\text { por ambos ao longo de toda a aliança }\end{array}$ \\
\hline & $\begin{array}{l}\text { Houve sinergia e complementariedade de competências, especialmente nos } \\
\text { projetos em que o escopo foi dividido em duas frentes (projetos e } \\
\text { investimentos) }\end{array}$ \\
\hline & $\begin{array}{l}\text { Modelo de "contrato guarda-chuva" combinado com "ordem de serviço" } \\
\text { permite total flexibilidade em cada cliente }\end{array}$ \\
\hline \multirow{3}{*}{ Criação de Valor } & $\begin{array}{l}\text { Aplicação de conhecimento de ambos os lados, assim como aprendizagem e } \\
\text { transferência de conhecimento ao longo dos trabalhos }\end{array}$ \\
\hline & $\begin{array}{l}\text { Ganho econômico para ambos, menor esforço comercial para a Gestiona e } \\
\text { menor esforço operacional para a PwC. No entanto, o ganho poderia ser maior } \\
\text { para a PwC caso optasse por se estruturar e atuar de forma independente }\end{array}$ \\
\hline & $\begin{array}{l}\text { Ganho institucional para ambos, maior credibilidade da marca para a Gestiona } \\
\text { no mercado de médias empresas, e para a PwC junto aos clientes satisfeitos }\end{array}$ \\
\hline $\begin{array}{l}\text { Nível de } \\
\text { Estabilidade } \\
\text { e } \\
\text { Eficácia }\end{array}$ & $\begin{array}{l}\text { O ponto de inflexão do nível de estabilidade e eficácia da aliança está no } \\
\text { falecimento do sócio sênior da PwC e sponsor interno da aliança com a } \\
\text { Gestiona. A não identificação de outros interlocutores da alta gestão da PwC } \\
\text { mostrou-se como a principal falha da Gestiona e causou a desestruturação da } \\
\text { aliança, mantida atualmente com base nos contratos vigentes }\end{array}$ \\
\hline
\end{tabular}

Fonte: o autor.

\subsection{Estrutura para análise dos riscos corporativos para a pequena empresa em Alianças Estratégicas com Grandes Empresas}

Partimos da aplicação de diversas teorias e modelos para identificar os riscos corporativos envolvidos na formação e durante a aliança estratégica entre a Gestiona e a PwC. Esses riscos, por sua vez, foram relacionados a diversas dimensões e/ou conceitos definidos de acordo com cada teoria. Dessa forma, o passo seguinte foi consolidar os riscos e as dimensões e, então, correlacioná-los de modo a permitir uma análise mais 
robusta. Posteriormente, identificamos e mensuramos, via grau de criticidade, seus possíveis impactos para a organização, no caso, a Gestiona. Na sequência, determinamos o nível de maturidade em gestão de riscos corporativos da Gestiona aplicando os fatores explicativos. E, por fim, analisamos o nível de estabilidade e eficácia da aliança entre Gestiona e PwC.

A partir de todos esses resultados, consolidamos os principais riscos e dimensões identificados, e propomos no Quadro 18 uma estrutura de riscos corporativos a serem analisados para a entrada e/ou continuidade em alianças estratégicas. Ressaltamos que no intuito de facilitar a conexão com as teorias e modelos, adotamos os três níveis: organizacional, ambiente de valor e ambiente de negócios, e as respectivas dimensões propostas por Oliva (2015).

Quadro 18 - Estrutura de riscos corporativos a serem analisados para a entrada e/ou continuidade em alianças estratégicas

\begin{tabular}{|c|c|c|}
\hline & Dimensão & Riscos a serem analisados antes e ao longo de uma aliança estratégica \\
\hline \multirow{4}{*}{ 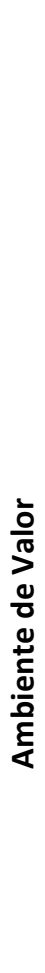 } & $\begin{array}{l}\text { Organiza- } \\
\text { cional }\end{array}$ & $\begin{array}{l}\text { 1. Relacionamento restrito a poucos integrantes da alta gestão do parceiro; } 2 \text {. } \\
\text { Conflitos de interesses e/ou prioridades distintas em todos os níveis } \\
\text { hierárquicos e áreas (diretoria, operacional e comercial); } 3 \text {. Imposições do elo } \\
\text { mais forte; } 4 \text {. Comunicação entre as partes geridas pelo parceiro; } 5 \text {. Diferenças } \\
\text { culturais insuperáveis ou prejudiciais à empresa; } 6 \text {. Falta de ética e/ou } \\
\text { transparência na relação entre as partes e com os clientes. }\end{array}$ \\
\hline & Operacional & $\begin{array}{l}\text { 1. Desempenho abaixo das expectativas; } 2 \text {. Desempenho acima das expectativas } \\
\text { (conflito de interesses); } 3 \text {. Necessidade de contratação e formação de mão de } \\
\text { obra; } 4 \text {. Alocação de profissionais (do parceiro) sem experiência nas equipes da } \\
\text { aliança; 5. Excesso de regras e procedimentos burocráticos exigidos pelo } \\
\text { parceiro; } 6 \text {. Comunicação com os clientes controlada pelo parceiro. }\end{array}$ \\
\hline & Estratégico & $\begin{array}{l}\text { 1. Dedicação excessiva da diretoria à aliança em detrimento de outras frentes de } \\
\text { atuação; } 2 \text {. Responsabilidades e direitos em caso de término da aliança; } 3 \text {. } \\
\text { Mercado potencial menor do que a expectativa; } 4 \text {. Transferência indesejada de } \\
\text { conhecimento ao longo dos trabalhos em conjunto; } 5 \text {. Fidelização dos clientes } \\
\text { com a grande empresa; } 6 \text {. Objetivos e prioridades estratégicas conflitantes; } 7 \text {. } \\
\text { Flexibilidade de contrato para cada cliente (escopo, responsabilidade e direitos). }\end{array}$ \\
\hline & Financeiro & $\begin{array}{l}\text { 1. Legislação tributária no contexto da aliança estratégica; } 2 \text {. Investimentos } \\
\text { necessários para atender à demanda relacionada à aliança; } 3 \text {. Poder de barganha } \\
\text { dos (grandes) clientes no que tange à remuneração pelos serviços. }\end{array}$ \\
\hline
\end{tabular}




\begin{tabular}{|c|c|c|}
\hline & Institucional & $\begin{array}{l}\text { 1. Visão (negativa) do mercado em relação ao novo posicionamento da empresa } \\
\text { em razão da aliança estratégica com a grande empresa; } 2 \text {. Visão (negativa) do } \\
\text { mercado em relação ao parceiro }\end{array}$ \\
\hline & Inovação & $\begin{array}{l}\text { Inovações que possam modificar o valor agregado dos serviços oferecidos pela } \\
\text { aliança }\end{array}$ \\
\hline & $\begin{array}{l}\text { Sustentabilida- } \\
\text { de ambiental }\end{array}$ & $\begin{array}{l}\text { Certificações e procedimentos exigidos pelo parceiro e/ou clientes para } \\
\text { prestação de serviços }\end{array}$ \\
\hline \multirow{5}{*}{ 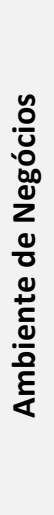 } & Político & Legislação relacionada aos serviços envolvidos na aliança \\
\hline & Econômico & Crises sistêmicas ou crises setoriais ligadas aos objetivos da aliança \\
\hline & Tecnológico & Novas tecnologias que possam afetar o portfólio de produtos da aliança \\
\hline & Social & Conflito de interesse entre setores da sociedade e os interesses da aliança \\
\hline & Meio ambiente & Novas regulamentações ambientais que impactem nos serviços da aliança \\
\hline
\end{tabular}

Fonte: o autor. 


\section{CONSIDERAÇÕES FINAIS}

Neste capítulo destacamos as conclusões, bem como as contribuições acadêmica e prática, as limitações da dissertação, além das possibilidades de pesquisas futuras.

\subsection{Conclusões}

A dissertação teve como principal objetivo propor uma estrutura para análise da gestão dos riscos corporativos no processo de formação e ao longo da aliança estratégica entre a Gestiona e a PwC. Para tanto, foram estabelecidos 5 objetivos específicos: (i) identificar e (ii) analisar os riscos corporativos para a Gestiona no processo de formação e ao longo da aliança estratégica com a PwC; (iii) avaliar o nível de maturidade da Gestiona em gestão de riscos corporativos; (iv) avaliar o nível de estabilidade e eficácia da aliança estratégica entre Gestiona e $\mathrm{PwC}$; e (v) propor um conjunto de fatores de risco a serem considerados no processo de formação e ao longo de aliança estratégica com outras empresas. Para atingi-los, as questões abaixo foram respondidas:

i. (Identificação) Quais são os riscos corporativos para a Gestiona no processo de formação e ao longo da aliança estratégica com a PwC?

Por meio da triangulação, ou seja, da combinação de métodos e fontes de coleta de dados, bem como da aplicação de teorias e modelos distintos, entre eles o COSO (2007), modelo conceitual para análise de riscos corporativos de Oliva (2015), teorias de Das e Teng (1998) e Maloni e Benton (1997), além do modelo de gestão de alianças estratégicas de alto compartilhamento, de Bruno e Vanconcellos (1999), foram identificados diversos riscos associados à diversas dimensões e/ou forças de origem, no contexto do processo de formação da aliança e pelo período de operação de 2 anos.

Em seguida, riscos e dimensões foram consolidados, gerando como resultado principal o Quadro 14: riscos e dimensões consolidadas.

ii. (Análise) Quais são os principais riscos corporativos e seus impactos para a Gestiona no processo de formação e ao longo da aliança estratégica com a PwC? 
Por meio da correlação entre os riscos consolidados identificados e os potenciais impactos para a organização (Gestiona), e da aplicação do conceito de grau de criticidade, chegamos à lista dos riscos mais relevantes a serem considerados no processo de formação e continuidade de uma aliança estratégica, tanto em termos absolutos quanto por dimensão consolidada, além de à sua relevância com base no grau de criticidade de cada dimensão consolidada, conforme Tabelas 6,7 e 8 respectivamente, respondendo, assim, à questão e satisfazendo ao respectivo objetivo específico.

iii. Qual é o nível de maturidade da Gestiona em gestão de riscos corporativos?

A aplicação do modelo de avaliação do nível de maturidade em gestão de riscos corporativos proposto por Oliva (2015) na Gestiona, considerando forças e eventos presentes nos três níveis - organização, ambiente de valor e ambiente de negócios -, além dos 4 fatores explicativos para as práticas de gestão de riscos corporativos, quais sejam: (i) organizacional; (ii) tecnicidade; (iii) transparência; e (iv) envolvimento; e, por fim, analisando os 5 níveis de maturidade, resultou no Nível 2 - GRC Contingencial para a Gestiona, como demonstra o Quadro 16.

iv. Qual o nível de estabilidade e eficácia da aliança estratégica entre Gestiona e PwC? A aplicação do modelo de gestão de alianças estratégicas de alto compartilhamento de Bruno (1999) na aliança estratégica entre Gestiona e PwC, considerando-se seus 2 primeiros anos, resultou no Quadro 17, que apresenta as características da aliança a partir das 4 dimensões definidas no modelo - institucional, organizacional, execução e criação de valor -, e culmina com o nível de estabilidade e eficácia da aliança, que, em última análise, demonstra a fragilidade da aliança, cujo ponto de inflexão do nível de estabilidade e eficácia da aliança foi o falecimento do sócio sênior da PwC e sponsor interno da aliança com a Gestiona. Além disso, a não identificação de outros interlocutores da alta gestão da PwC mostrou-se a principal falha da Gestiona e causou a desestruturação da aliança, mantida atualmente com base nos contratos vigentes.

v. Quais riscos corporativos devem ser considerados no processo de formação e ao 
longo de aliança estratégica com outras empresas?

A partir de todos esses resultados, consolidamos os principais riscos e dimensões identificados, e propomos uma estrutura de riscos corporativos (não exaustiva) a serem analisados para a entrada e continuidade em alianças estratégicas, com base nas dimensões presentes nos três níveis de atuação: organizacional, ambiente de valor e ambiente de negócios, propostas por Oliva (2015).

Dessa forma, entendemos que tanto o objetivo geral quanto os objetivos específicos desta dissertação foram atendidos de forma producente tanto no que diz respeito à teoria quanto à prática.

\subsection{Contribuições para teoria}

Espera-se que a dissertação tenha apresentado originalidade e agregado conhecimento relevante à teoria, uma vez que há uma tendência de aumento de alianças estratégicas em todos os setores da economia e relativamente poucos estudos neste campo do conhecimento, especialmente no Brasil.

Nesse sentido, a estrutura de riscos corporativos a serem analisados para a entrada e continuidade em alianças estratégicas tem forte correlação com as diversas teorias e modelos conceituais envolvendo gestão de riscos corporativos e alianças estratégicas, o que facilita a realização de novos estudos na área. Também vale ressaltar a aplicação de 2 modelos teóricos relacionados à gestão de riscos corporativos - o nível de maturidade de Oliva (2015) e o nível de estabilidade e eficácia em alianças estratégicas de Bruno (1999).

\subsection{Contribuições práticas}

Em termos práticos, espera-se que a dissertação, especialmente o Quadro 18, possa ser utilizada como apoio para orientar empreendedores e decisores em geral na tomada de decisão em relação a uma potencial aliança estratégica, sobretudo em casos semelhantes, ou seja, empresas prestadoras de serviços B2B, uma vez que aspectos 
fundamentais para a indústria, por exemplo, tiveram pouca ou nenhuma relevância neste estudo, tais como os agentes Distribuidores e Fornecedores e as dimensões sustentabilidade ambiental e inovação. Em suma, embora não exaustiva, a estrutura para análise de riscos apresentada nesta dissertação, pode ajudar o empreendedor ou decisor a considerar outras ameaças e potencias problemas, tanto antes quanto durante a aliança.

Este estudo mostrou a importância do relacionamento interpessoal para o sucesso (ou fracasso) da aliança estratégica, como pode ser visto nos diversos riscos identificados e analisados ao longo da aliança nas principais dimensões.

1. Organizacional: Relacionamento restrito a poucos integrantes da alta gestão do parceiro; Conflitos de interesses e/ou prioridades distintas em todos os níveis hierárquicos e áreas (diretoria, operacional e comercial); Imposições do elo mais forte; Comunicação entre as partes geridas pelo parceiro; Diferenças culturais.

2. Operacional: desempenho (acima ou abaixo) das expectativas; contratação, formação e alocação de mão de obra; burocracia excessiva; e comunicação com o cliente;

3. Estratégico: dedicação excessiva da diretoria; responsabilidades e direitos; transferência indesejada de know how; objetivos e prioridades conflitantes.

Todos os riscos acima podem ser minimizados (ou maximizados) dependendo da qualidade do relacionamento humano entre as partes.

Outros riscos, por exemplo, de origem financeira, tecnológica, social e ambiental, mostram-se menos relevantes para o sucesso (ou fracasso) da aliança.

\subsection{Limitações da dissertação}

Segundo Laville e Dionne (1999, p. 35), em ciências humanas o pesquisador pode influenciar seu objeto de pesquisa, ainda mais tendo uma participação ativa no caso em questão. O objeto de estudo, por sua vez, é capaz de ter comportamentos diversos que podem ser voluntários ou não, conscientes ou não. Isso tem como consequência um estudo do conhecimento que, embora construído sob métodos e prudência, pode variar em seus resultados, dando-lhes características de não serem nem exclusivos nem absolutos. 
Isso posto, rigorosamente as conclusões aqui apresentadas são preliminares e relativas apenas ao caso estudado. Isso certamente não as coloca em posição de serem consideradas extensíveis e aplicáveis a qualquer empresa; no entanto, entendemos que o resultado final - a estrutura de riscos corporativos a serem analisados para a entrada e continuidade em alianças estratégicas - pode contribuir para a tomada de decisão, especialmente no caso de empreendedores e decisores do setor de serviços B2B que estejam considerando a possibilidade de atuar ou que já estejam em uma aliança estratégica com outra empresa.

\subsection{Pesquisas futuras}

Como oportunidade para ampliação deste campo do conhecimento, sugerimos que sejam feitos estudos de casos múltiplos envolvendo empresas com as mesmas características propostas e também pesquisas quantitativas, com o objetivo de definir o grau de relevância dos riscos sugeridos nesta dissertação. 


\section{REFERÊNCIAS}

A Maturity Model for Enterprise Risk Management. International Journal of Production Economics, v. 173, p. 66-79, 2015.

ADOBOR, H. Inter-Firm Collaboration: Configurations and Dynamics. Competitiveness Review; 16, 2, p.122, 2006.

ANSOFF, H. I. Corporate Strategy. New York: Mc Graw Hill, p. 105-116, 1965. A nova estratégia empresarial. São Paulo: Atlas, 1990.

ASSOCIAÇÃO BRASILEIRA DE NORMAS TÉCNICAS. ABNT. NBR ISO 31000: Gestão de Riscos - Princípios e diretrizes. Rio de Janeiro: ABNT, 2009.

BALLOU, R. H. Gerenciamento da Cadeia de Suprimentos: planejamento, organização e logística empresarial. Porto Alegre: Bookmam. 2001.

BRUNO M.A.C. Gestão de Cooperação Técnica entre empresas e estratégia empresarial: estudos de caso no Setor Químico. Tese de Doutorado. Faculdade de Economia, Administração e Contabilidade da Universidade de São Paulo. 1995.

BRUNO M.A.C., VASCONCELLOS E. Effectiveness in the management of strategic technological aliances: conceptual framework and apllication to the chemical industry. Tecnology Management, v. 3., n. 4, p 313-327, 1997.

CHOPRA, S., \& SODHI, M.S. Managing Risk to Avoid Supply-Chain Breakdown. MIT Sloan Management Review. 2004.

CHRISTOPHER, M., \& Peck, H. Building the resilient supply chain. International Journal of Logistics Management, p. 1-14, 2004.

CONTRACTOR, F. J.; LORANGE, P. Why should firms cooperate? The strategy and economics basis for cooperation ventures. In: Cooperative Strategies in International Business: Joint Ventures and Technology Partnerships between Firms, Lexington, MA: Lexington Books, 1988.

COSO. Committee of Sponsoring Organisation of Treadway Commission. Enterprise Risk management. Integrated framework. Executive Summary. September, 2004. Disponível em: <http://www.coso.org/documents/coso_erm_executivesummary.pdf $>$. Acesso em 05/04/2016. 
COSO. Committee of Sponsoring Organisation of Treadway Commission. Gerenciamento de riscos corporativos - estrutura integrada: sumário executivo. 2007. Disponível

em: $<$ http://www.coso.org/publications/erm/coso_erm_executivesummary.pdf $>$. Acesso em 05/04/2016.

COSO. Committee of Sponsoring Organisation of Treadway Commission. Controle interno - estrutura integrada: sumário executivo (Tradução livre do original em inglês), dezembro de 2014. Acesso em 05/04/2016. Disponível em: < http://www.pwc.com.br/pt_BR/br/auditoria-interna/assets/coso-13.pdf>.

CROUHY, Michel; GALAY, Dan; MARK, Robert. Gerenciamento de risco: abordagem conceitual e prática. Uma visão integrada dos riscos de crédito, operacional e de mercado. Rio de Janeiro: Qualitymark, 2004.

DACIN, T.; HITT, M.; LEVITAS, E.: Selecting Partners for Successful International Alliances: Examination of U.S. and Korean Firms. Journal of World Business, vol. 32, n.1, p. 3-16, 1997.

DEVLIN, G.; BLEACKLEY, M. Strategic Alliances - Guidelines for Success. Long Range Planning, vol. 21, n. 5, p.18-23, 1988.

DIEHL, Astor. A.; TATIM, Denise. C. Pesquisa em ciências sociais aplicadas: métodos e técnicas. São Paulo: Prentice Hall, 2004.

DODGSON, M. Technological Collaboration in Industry - Strategy, Policy and Internationalization in Innovation. Routledge, NY, 1993.

EISENHARDT, K.M. Building theories from case study research. Academy of Management Review; Oct; 14, 4; ABI/INFORM Global, p. 532, 1989.

ELORANTA, J. Internal Corporate Venturing: context and definition. Helsinky University of Technology. Seminar in Strategy and International Business, 2000.

EMULTI, D. Y KATHWALA, Y. An Overview of Strategic Alliances. Management Decision, vol. 39, n.3, p.205-217, 2001.

FERRAZ, Marcelo. Utilização de derivativos exóticos no gerenciamento de risco em empresas. In: DUARTE JR., Antonio. M.; VARGA, Gyorgy. (org.). Gestão de riscos no Brasil. Rio de Janeiro: Financial Consultoria, p. 783-809, 2003.

GAJ, L. Tornando a estratégia competitiva possível. São Paulo: McGraw-Hill, 1990. 
GIL, A. C. Como Elaborar Projetos de Pesquisa. São Paulo: Atlas, p.45-47, 118, 1988.

HARBISON, J. R.; PEKAR Jr., P. Smart Alliances: A Practical Guide to Repeatable Success. Jossey Bass: USA, 1998.

HARRIGAN K. R. Joint Ventures and Competitive Strategy. Strategic Management Journal, Vol. 9, 1988.

KEIL, T. External Corporate Venturing: Cognition, Speed and Capability Development. Doctoral Thesis. Helsinky University of Technology. Espoo-Finland, 2000. Disponível em http://www.tuta.hut.fi/isib . Acesso em 18.10.2016.

KLOTZE, M.C. Alianças Estratégicas: Conceito e Teoria. Revista de Administração Contemporânea - RAC. vol.6, n.1, jan-abr, p.85-104, 2002.

KOSIOL, Erich. Zur problematik der planung in der unternehmung. In: Zeitschrift für Betriebswirtschaft (ZfB), 37, Jg. p. 77-96, 1967.

KOZA, M.P.; LEWIN, A.Y. The Co-evolution of Strategic Alliances. Organizational Science, vol. 9, n. 3, p. 255-264, 1998.

. Managing Partnerships and Strategic Alliances: Raising the Odds of Success. European Management Journal, vol. 16, n. 2, p. 146-151, 2000.

- Strategic alliances and partner asymmetries. In: CONTRACTOR, F. J.; LORANGE, P. Cooperative strategies in international business. Lexington: Lexington Books, p. 205-226, 1988.

KRÓLAS, Pawel; KRÓLAS, L. Risk in Management Systems according to ISO standart. Published quarterly as the organ of the Foundry Commission of the Polish Academy of Sciences. Archives of Foundry Engineering. Volume 10, Special Issue 3, pp. 149-152, 2010.

HAIR Jr, Joseph F.; BLACK, William C.; BABIN, Barry J.; ANDERSON, Rolph E.; TATHAM, Ronald L.; Análise multivariada de dados. Porto Alegre: Bookman, 2005.

HARBISON, J. R.; PEKAR Jr., P. Smart Alliances: A Practical Guide to Repeatable Success. Jossey Bass: USA, 1998.

HILLSON, D. A. Towards a Risk Maturity Model. The International Journal of Project \& Business Risk Management, p. 35-45, 1997. 
HITT, M.A., DACIN, M.T., LEVITAS, E., ARREGLE, J-L.; BORZA, A. Partner Selection in Emerging and Developed Market Contexts: Resource-Based and Organizational Learning Perspectives. Academy of Management Journal, vol. 43, n. 3, p. 449-467, 2000.

HITT, M.A., HARRISON, J.S. y IRELAND, R.D. Mergers and Acquisitions: A Guide to Creating Value for Stakeholders. New York: Oxford University Press, 2001.

JONASH, R. S.; SOMMERLATTE, T. O valor da inovação - como as empresas mais avançadas atingem alto desempenho e lucratividade. Arthur D. Little, Inc. Rio de Janeiro: Campus, p. 1-11; 26-41, 2001.

LAVILLE, Christian; DIONNE, Jean. A construção do saber: manual de metodologia da pesquisa em ciências humanas. Belo Horizonte: Editora UFMG, 1999.

LEVITAS, E.; HITT, M. A.; DACIN, M. T. Competitive Intelligence and Tacit Knowledge Development in Strategic Alliances. Competitive Intelligence Review. vol.8, n. 2, p. 20-27, 1997.

LORANGE, P.; ROOS, J.; BRONN, P. Building Successful Strategic Alliances. Longe Range Planning, vol. 25, n. 6, pp. 10-17, 1992.

LORANGE, P., ROOS, J. Alianças Estratégicas: formação, implementação e evolução. São Paulo: Atlas, 1996.

LUND, Mass S.; SOLHAUG, Bjørnar; STOLEN, Ketil. Evolution in relation to risk and trust management, Oslo, IEEE Computer, vol. 43, n. 5, pp. 49-55, May, 2010.

MALONI, M. J.; BENTON, W. C. Supply chain partnerships: Opportunities for operations researh. European Journal of Operational Research, v.101, n.3, Sep 16, p.419-429. 1997.

MANUJ, I.; MENTZER, J. T. Global supply chain risk management. Journal of Business Logistics, 29: p. 133-156, 2008.

MARCONI, Marina A.; LAKATOS, Eva M. Fundamentos de metodologia científica. 6. ed. São Paulo: Atlas, 2010.

MEDCOF, J.W. Why Too Many Alliances End in Divorce. Long Range Planning, vol. 30, n. 5, p. 718-732, 1997. 
OLIVA, F. L.; SOBRAL, M. C.; DAMASCENO, F.; TEIXEIRA, H. J.; GRISI, C. C. H.; FISCHMANN, A. A.; SANTOS, S. A. Risks and Strategies in a Brazilian Innovation - Flexfuel Technology. Journal of Manufacturing Technology Management, Birmingham, Inglaterra, 2013.

OLIVA, F. L. (2015). Maturity Model for Enterprise Risk Management: A Research for Brazilian Companies. International Journal of Production Economics,, 173(3), 66-79.

PEKAR, P. JR.; ALLIO, R. Making Alliances Work: Guidelines for Success. Long Range Planning, vol. 27, n.4, p. 54-65, 1994.

RICHARDSON, Roberto J. Pesquisa social: métodos e técnicas. São Paulo: Atlas, 1999.

ROBERTS, E. B.; BERRY, C. A. Entering New Businesses - Selecting Strategies for Success. MIT Sloan Management Review, Cambridge, MA, spring 1985. p. 3-17.

SORENSEN, H.B., REVE, T. Forming Strategic Alliances for Asset Development. Scandinavian Journal of Management, vol. 14, n. 3, p. 151-165, 1998.

STAFFORD, E. R. Using Co-operative Strategies to Make Alliances Work. Long Range Planning, vol. 27, n.3, p. 64-74, 1994.

VARADARAJAN, P.R.; CUNNINGHAM, M. H. Strategic Alliances: A synthesis of Conceptual Foundations, Journal of the Academy of Marketing Science, vol. 23, n. 4, p. 282-296, 1995.

VERSCHOORE FILHO, Jorge R. S. Redes de cooperação interorganizacionais: a identificação de atributos e benefícios para um modelo de gestão. 2006. Tese (Doutorado) - Programa de Pós-Graduação em Administração da Escola de Administração da Universidade Federal do Rio Grande do Sul, Porto Alegre, Rio Grande do Sul, Brasil, 2006.

WILLIANSON O.E. Transaction Cost Economics: Governance of Contractual Relations, Journal of Law and Economics, 22, n.1, p. 233-261, 1979.

YIN, R. K. Estudo de Caso - Planejamento e Método. 2. ed. São Paulo: Bookman, 2010. 


\section{Sites pesquisados}

http://gestiona.com.br/a-gestiona/. Consultado em 23/07/2016.

http://www.bndes.gov.br/SiteBNDES/bndes/bndes_pt/Institucional/Apoio_Financeiro/p orte.html. Consultado em 29/06/2016.

http://www.pwc.com.br/pt/quem-somos/index.jhtml. Consultado em 29/06/2016.

http://www.sebrae-sc.com.br/leis/default.asp?vcdtexto=4154. Consultado em 29/06/2016. 


\section{APÊNDICES}

\section{APÊNDICE 1 - QUESTIONÁRIO}

\begin{tabular}{|lc|}
\hline & $\begin{array}{c}\text { Questionário integrante da Pesquisa Acadêmica FEA-USP intitulada: } \\
\text { Riscos Corporativos em Alianças Estratégicas: } \\
\text { o caso envolvendo a Gestiona - pequena empresa e a PwC }\end{array}$ \\
\hline Nome: & Data: \\
E-mail: & Telefone: \\
\hline
\end{tabular}

\begin{tabular}{|c|c|c|c|}
\hline A. & \multicolumn{3}{|l|}{ Perfil do Entrevistado } \\
\hline & \multicolumn{3}{|l|}{ Idade } \\
\hline & ( ) 25 ou menos & ( ) 26 a 35 & ( ) 36 a 45 \\
\hline & ( ) 46 a 55 & ( ) 56 a 65 & ( ) 66 ou mais \\
\hline & \multicolumn{3}{|l|}{ Escolaridade } \\
\hline & ( ) Ensino Médio Incompleto & \multicolumn{2}{|c|}{ ( ) Superior Completo } \\
\hline & ( ) Ensino Médio Completo & \multicolumn{2}{|c|}{ ( ) Pós-graduado Incompleto } \\
\hline & ( ) Superior Incompleto & \multicolumn{2}{|c|}{ ( ) Pós-graduado Completo (MBA, Mestrado, Doutorado) } \\
\hline & \multicolumn{3}{|l|}{ Tempo de serviço na empresa } \\
\hline & ( ) Até 2 anos & \multicolumn{2}{|l|}{ ( ) 8 a 10 anos } \\
\hline & ( ) 2 a 4 anos & \multicolumn{2}{|l|}{ ( ) 11 a 15 anos } \\
\hline & ( ) 5 a 7 anos & \multicolumn{2}{|l|}{ ( ) 16 anos ou mais } \\
\hline & \multicolumn{3}{|l|}{ Cargo atual } \\
\hline & ( ) Proprietário/Sócio & ( ) Diretor & ( ) Associado \\
\hline & ( ) Gerente Sênior & ( ) Gerente Pleno & ( ) Gerente Jr. \\
\hline & \multicolumn{3}{|c|}{ ( ) Outro: } \\
\hline & \multicolumn{3}{|l|}{ Tempo no cargo atual } \\
\hline & ( ) Até 2 anos & \multicolumn{2}{|l|}{ ( ) 8 a 10 anos } \\
\hline & ( ) 2 a 4 anos & \multicolumn{2}{|l|}{ ( ) 11 a 15 anos } \\
\hline & ( ) 5 a 7 anos & \multicolumn{2}{|l|}{ ( ) 16 anos ou mais } \\
\hline
\end{tabular}

B.

\begin{tabular}{|c|c|}
\hline \multicolumn{2}{|l|}{ Perfil da organização } \\
\hline \multicolumn{2}{|l|}{ Ano de fundação: } \\
\hline \multicolumn{2}{|l|}{ Presença no Brasil: } \\
\hline \multicolumn{2}{|l|}{ Segmento } \\
\hline ( ) Indústria & ( ) Comércio \\
\hline \multicolumn{2}{|c|}{ Porte quanto ao número de empregados (SEBRAE) } \\
\hline Indústria & Comércio ou Serviços \\
\hline ( ) Micro: até 19 & ( ) Micro: até 19 \\
\hline ( ) Pequeno: 20 a 99 & ( ) Pequeno: 20 a 99 \\
\hline ( ) Médio: 100 a 499 & ( ) Médio: 100 a 499 \\
\hline
\end{tabular}


( ) Grande: 500 ou mais

( ) Grande: 500 ou mais

Porte quanto à Receita Bruta Anual (BNDES)

( ) Micro: menor ou igual a $\mathrm{R} \$ 2,4$ milhões

( ) Pequeno: maior que $\mathrm{R} \$ 2,4$ milhões e menor ou igual a $\mathrm{R} \$ 16$ milhões

( ) Médio: maior que $\mathrm{R} \$ 16$ milhões e menor ou igual a $\mathrm{R} \$ 90$ milhões

( ) Médio-grande: maior que $\mathrm{R} \$ 90$ milhões e menor ou igual a $\mathrm{R} \$ 300$ milhões

( ) Grande: maior que $\mathrm{R} \$ 300$ milhões

Mercados atuantes

( ) local

( ) regional

( ) nacional

( ) internacional

C. Ambiente de Valor

\begin{tabular}{|c|c|}
\hline Clientes & Qual é o perfil e porte dos clientes? \\
\hline Concorrentes & Qual é o perfil e porte dos concorrentes? \\
\hline Fornecedores & Qual o papel dos fornecedores nos negócios da organização? \\
\hline Distribuidores & Qual o papel dos distribuidores nos negócios da organização? \\
\hline Governo & Qual o papel do Governo nos negócios da organização? \\
\hline Sociedade & Qual o impacto da atuação da organização na sociedade? \\
\hline
\end{tabular}

D. Objetivos e componentes do gerenciamento de riscos corporativos

\begin{tabular}{|c|c|}
\hline Ambiente interno & $\begin{array}{l}\text { Como são a estrutura e a estratégia organizacionais? A atuação da alta administração? } \\
\text { As políticas e controles internos? }\end{array}$ \\
\hline Fixação de objetivos & $\begin{array}{l}\text { Quais os principais objetivos da organização em termos: estratégico, operacional, } \\
\text { comunicação e conformidade? }\end{array}$ \\
\hline $\begin{array}{l}\text { Identificação de } \\
\text { eventos }\end{array}$ & Como a organização identifica eventos em potencial (oportunidades e ameaças)? \\
\hline$\frac{\text { Avaliação de riscos }}{\text { (ISO) }}$ & Como a organização avalia os riscos potenciais? \\
\hline Resposta ao risco & $\begin{array}{l}\text { Qual a postura preponderante da organização diante do risco? } \\
\begin{array}{lll}\text { ( ) evitar } & \text { ( ) reduzir } & \text { ( ) compartilhar }\end{array}\end{array}$ \\
\hline Atividades de controle & $\begin{array}{l}\text { Quais as políticas e os procedimentos para assegurar a execução das respostas aos } \\
\text { riscos? }\end{array}$ \\
\hline$\frac{\text { Informações e }}{\text { comunicações }}$ & $\begin{array}{l}\text { Como é feita a comunicação sobre o nível de riscos e o respectivo tratamento com } \\
\text { base nos critérios de risco estabelecidos? }\end{array}$ \\
\hline Monitoramento & Como é feito o acompanhamento e monitoramento ao longo das atividades? \\
\hline
\end{tabular}

E. Contexto da Aliança Estratégica entre pequena (Gestiona) e grande organização (PwC)

\begin{tabular}{|l|l|}
\hline Motivação & Quais os motivos para a formação da Aliança Estratégica? \\
\hline$\frac{\text { Natureza dos }}{\text { produtos/serviços }}$ & Quais os produtos/serviços envolvidos na Aliança Estratégica? \\
\hline
\end{tabular}




\begin{tabular}{|l|l|}
\cline { 2 - 2 } Ambiente & Qual foi a expectativa inicial da aliança no que tange aos seguintes fatores: \\
\cline { 2 - 3 } & \# Estratégico \\
\hline \# Financeiro \\
\cline { 2 - 3 } & \# Operacional \\
\cline { 2 - 3 } & \# Imagem \\
\hline \# Ético \\
\hline & \# Inovação \\
\hline & \# Sustentabilidade ambiental \\
\hline & Qual foi a expectativa inicial da aliança no que tange aos seguintes fatores: \\
\hline & \# Econômico \\
\hline & \# Político \\
\hline & \# Tecnológico \\
\cline { 2 - 2 } & \# Social \\
\hline & \# Meio ambiente \\
\hline
\end{tabular}

\section{F. Aliança Estratégica de alto compartilhamento}

\begin{tabular}{|c|c|}
\hline \multirow{5}{*}{ Institucional } & Como é a relação interpessoal entre os membros de cada organização? \\
\hline & Há conflitos entre os propósitos de cada organização? \\
\hline & Qual o histórico das relações entre as organizações? \\
\hline & A excelência está entre os princípios da organização? Comente. \\
\hline & Como é a interlocução entre as organizações? \\
\hline \multirow{5}{*}{ Organizacional } & Há tolerância para as diferenças culturais? Comente. \\
\hline & Os princípios e valores são convergentes ou conflitantes? Comente. \\
\hline & Nota-se honestidade e ética na relação? Comente. \\
\hline & Há transparência na relação entre as organizações? \\
\hline & Como é a comunicação entre as organizações? \\
\hline \multirow{4}{*}{ Execução } & Como é definida a pauta de interação entre as organizações e os clientes? \\
\hline & $\begin{array}{l}\text { Como é feita a definição de escopo, obrigações e responsabilidades de cada parte na } \\
\text { execução dos trabalhos? }\end{array}$ \\
\hline & Como é feita a adequação do contrato em cada cliente e a divisão da remuneração? \\
\hline & Há flexibilidade nos contratos? Comente. \\
\hline \multirow{6}{*}{ Criação de Valor } & Há domínio e/ou aplicação do conhecimento técnico? Comente. \\
\hline & Houve/há ganho financeiro para sua organização? Comente. \\
\hline & Houve/há ganho ou perda institucional? Comente. \\
\hline & Houve/há ganho de aprendizagem da sua organização? \\
\hline & Como tem sido o feedback dos clientes em relação aos trabalhos realizados? \\
\hline & Houve fidelização dos clientes? Comente. \\
\hline
\end{tabular}

